\title{
Formoterol versus short-acting beta-agonists as relief medication for adults and children with asthma (Review)
}

\author{
Welsh EJ, Cates CJ
}

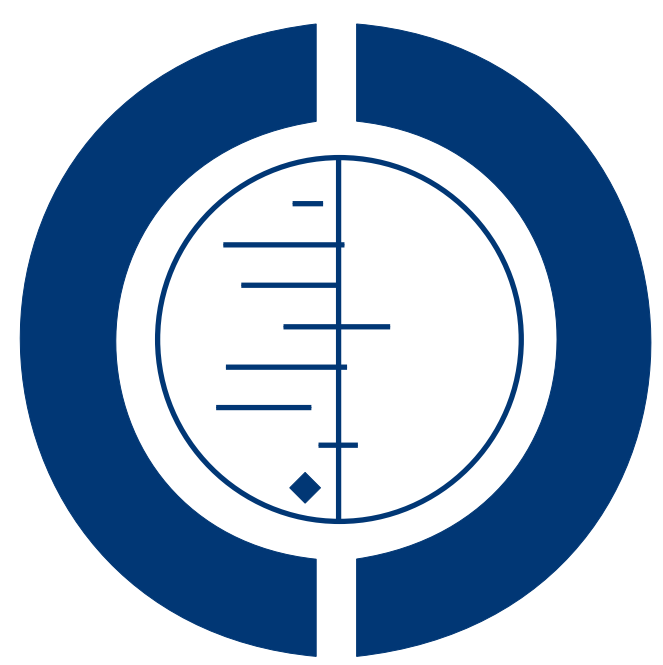

\section{THE COCHRANE COLLABORATION $^{\circledR}$}

This is a reprint of a Cochrane review, prepared and maintained by The Cochrane Collaboration and published in The Cochrane Library 2010, Issue 9

http://www.thecochranelibrary.com

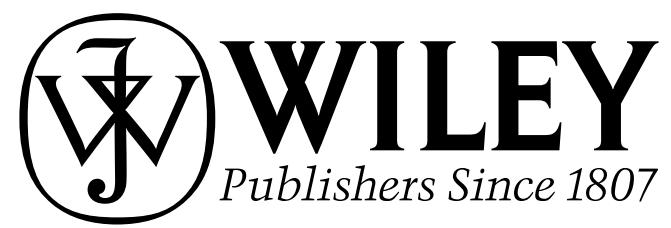

Formoterol versus short-acting beta-agonists as relief medication for adults and children with asthma (Review)

Copyright (C) 2010 The Cochrane Collaboration. Published by John Wiley \& Sons, Ltd. 
TABLE OF CONTENTS

HEADER . . . . . . . . . . . . . . . . . . . . . . . . . . . . . . . . 1

ABSTRACT .. . . . . . . . . . . . . . . . . . . . . . . . . . . . . . . . . . . . . . . . . . . . . . . . .

PLAIN LANGUAGE SUMMARY . . . . . . . . . . . . . . . . . . . . . . . . . . . . . . . . . . . . . . . $\quad . \quad 2$

SUMMARY OF FINDINGS FOR THE MAIN COMPARISON . . . . . . . . . . . . . . . . . . . . . . . 2

BACKGROUND . . . . . . . . . . . . . . . . . . . . . . . . . . . . . . . . . . . . 5

OBJECTIVES . . . . . . . . . . . . . . . . . . . . . . . . . . . . . . . . . . . . . 5

METHODS . . . . . . . . . . . . . . . . . . . . . . . . . . . . . . . . . . . . . . 5

RESUlTS . . . . . . . . . . . . . . . . . . . . . . . . . . . . . . . . . . . . . . . 47

Figure 1. . . . . . . . . . . . . . . . . . . . . . . . . . . . . . . . . . . . . . . . . 9

Figure 2. . . . . . . . . . . . . . . . . . . . . . . . . . . . . . . . . . . . . . 11

Figure 3. . . . . . . . . . . . . . . . . . . . . . . . . . . . . . . . . . . . . . 12

Figure $4 . \quad$. . . . . . . . . . . . . . . . . . . . . . . . . . . . . . . . . . . . . 12

Figure 5. . . . . . . . . . . . . . . . . . . . . . . . . . . . . . . . . . . . . . 13

Figure 6. . . . . . . . . . . . . . . . . . . . . . . . . . . . . . . . . . . . . . 14

Figure $7 . \quad$. . . . . . . . . . . . . . . . . . . . . . . . . . . . . . . . . . . . . 14

Figure 8. . . . . . . . . . . . . . . . . . . . . . . . . . . . . . . . . . . . . . 15

Figure 9. . . . . . . . . . . . . . . . . . . . . . . . . . . . . . . . . . . . . . 16

DISCUSSION . . . . . . . . . . . . . . . . . . . . . . . . . . . . . . . . . . . . . . . . . . . . 17

AUTHORS' CONCLUSIONS . . . . . . . . . . . . . . . . . . . . . . . . . . . . . . . . . . . . . . 18

ACKNOWLEDGEMENTS . . . . . . . . . . . . . . . . . . . . . . . . . . . . . . . . . . . . . . 19

REFERENCES . . . . . . . . . . . . . . . . . . . . . . . . . . . . . . . . . . . . . 19

CHARACTERISTICS OF STUDIES . . . . . . . . . . . . . . . . . . . . . . . . . . . . . . . . . . . . . . . . . 22

DATA AND ANALYSES . . . . . . . . . . . . . . . . . . . . . . . . . . . . . . . . . . . . . . . . . . . . . . . 38

Analysis 1.1. Comparison 1 Formoterol versus short-acting beta2-agonist, Outcome 1 Patients with an exacerbation requiring hospitalisation. . . . . . . . . . . . . . . . . . . . . . . . . . . . . . . . . . .

Analysis 1.2. Comparison 1 Formoterol versus short-acting beta2-agonist, Outcome 2 Patients with an exacerbation

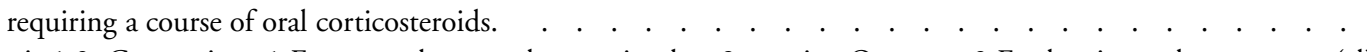

Analysis 1.3. Comparison 1 Formoterol versus short-acting beta2-agonist, Outcome 3 Fatal serious adverse events (allcause).

Analysis 1.4. Comparison 1 Formoterol versus short-acting beta2-agonist, Outcome 4 Patients with a serious adverse event (all-cause).

Analysis 1.5. Comparison 1 Formoterol versus short-acting beta2-agonist, Outcome 5 Patients with a serious adverse event (asthma-related). . . . . . . . . . . . . . . . . . . . . . . . . . . . . . . . . . 43

Analysis 1.6. Comparison 1 Formoterol versus short-acting beta2-agonist, Outcome 6 Peak expiratory flow (morning). 44

Analysis 1.7. Comparison 1 Formoterol versus short-acting beta2-agonist, Outcome 7 Peak expiratory flow (evening). 45

Analysis 1.8. Comparison 1 Formoterol versus short-acting beta2-agonist, Outcome 8 Fixed expiratory flow in one second (FEV1) litres.

Analysis 1.9. Comparison 1 Formoterol versus short-acting beta2-agonist, Outcome 9 Change in FEV1 \% predicted.

Analysis 1.10. Comparison 1 Formoterol versus short-acting beta2-agonist, Outcome 10 Withdrawals (any reason). .

Analysis 2.1. Comparison 2 Formoterol versus short-acting beta2-agonist (background ICS use), Outcome 1 Patients with an exacerbation requiring a course of oral corticosteroids. . . . . . . . . . . . . . . . . . . . 48

Analysis 2.2. Comparison 2 Formoterol versus short-acting beta2-agonist (background ICS use), Outcome 2 Patients with a serious adverse event (all-cause).

Analysis 3.1. Comparison 3 Formoterol versus short-acting beta2-agonists (background LABA use), Outcome 1 Patients with a serious adverse event (all-cause). . . . . . . . . . . . . . . . . . . . . . . . . . 50

ADDITIONAL TABLES . . . . . . . . . . . . . . . . . . . . . . . . . . . . . . . . . . . . . . . 50

HISTORY . . . . . . . . . . . . . . . . . . . . . . . . . . . . . . . . . . . . . . . 52

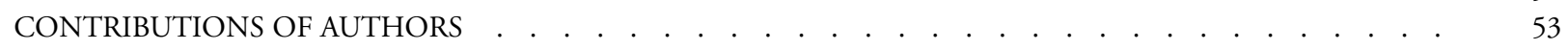

DECLARATIONS OF INTEREST . . . . . . . . . . . . . . . . . . . . . . . . . . . . . . . . . . . . . 53

SOURCES OF SUPPORT . . . . . . . . . . . . . . . . . . . . . . . . . . . . . . . . . . . . . . . . . . . . 53

DIFFERENCES BETWEEN PROTOCOL AND REVIEW

Formoterol versus short-acting beta-agonists as relief medication for adults and children with asthma (Review)

Copyright $\odot 2010$ The Cochrane Collaboration. Published by John Wiley \& Sons, Ltd. 
Copyright (@) 2010 The Cochrane Collaboration. Published by John Wiley \& Sons, Ltd. 


\title{
[Intervention Review]
}

\section{Formoterol versus short-acting beta-agonists as relief medication for adults and children with asthma}

\author{
Emma J Welsh ${ }^{1}$, Christopher J Cates ${ }^{1}$ \\ ${ }^{1}$ Population Health Sciences and Education, St George's, University of London, London, UK \\ Contact address: Emma J Welsh, Population Health Sciences and Education, St George's, University of London, Cranmer Terrace, \\ London, SW17 0RE, UK. ewelsh@sgul.ac.uk. \\ Editorial group: Cochrane Airways Group. \\ Publication status and date: New, published in Issue 9, 2010. \\ Review content assessed as up-to-date: 18 July 2010.
}

Citation: Welsh EJ, Cates CJ. Formoterol versus short-acting beta-agonists as relief medication for adults and children with asthma. Cochrane Database of Systematic Reviews 2010, Issue 9. Art. No.: CD008418. DOI: 10.1002/14651858.CD008418.pub2.

Copyright (C) 2010 The Cochrane Collaboration. Published by John Wiley \& Sons, Ltd.

\begin{abstract}
A B S T R A C T
Background

Formoterol is a long-acting beta 2 -agonist but because it has a fast onset of action it can also be used as a relief medication.

Objectives

To asses the efficacy and safety of formoterol as reliever therapy in comparison to short-acting beta2-agonists in adults and children with asthma.

Search methods

We searched the Cochrane Airways Group Specialised Register and websites of clinical trial registers (for unpublished trial data), and we checked the Food and Drug Administration (FDA) submissions in relation to formoterol. The date of the most recent search was February 2010.
\end{abstract}

\section{Selection criteria}

Randomised, parallel-arm trials of at least 12 weeks duration in patients of any age and severity of asthma. Studies randomised patients to any dose of as-needed formoterol versus short-acting beta 2 -agonist. Concomitant use of inhaled corticosteroids or other maintenance medication was allowed, as long as this was not part of the randomised treatment regimen.

\section{Data collection and analysis}

Two authors independently selected trials for inclusion in the review. Outcome data were extracted by one author and checked by the second author. We sought unpublished data on primary outcomes.

\section{Main results}

This review includes eight studies conducted in 22,604 participants (mostly adults). Six studies compared formoterol as-needed to terbutaline whilst two studies compared formoterol with salbutamol as-needed. Background maintenance therapy varied across the trials. Asthma exacerbations and serious adverse events showed a direction of treatment effect favouring formoterol, of which one outcome reached statistical significance (exacerbations requiring a course of oral corticosteroids). In patients on short-acting beta2agonists, 117 people out of 1000 had exacerbations requiring oral corticosteroids over 30 weeks, compared to 101 (95\% CI 93 to 108) out of 1000 for patients on formoterol as-needed. In patients on maintenance inhaled corticosteroids there were also significantly fewer exacerbations requiring a course of oral corticosteroids on formoterol as-needed (Peto OR 0.75; 95\% CI 0.62 to 0.91 ). There was one death per 1000 people on formoterol or on short-acting beta 2 -agonists. 


\section{Authors' conclusions}

In adults, formoterol was similar to short-acting beta 2 -agonists when used as a reliever, and showed a reduction in the number of exacerbations requiring a course of oral corticosteroids. Clinicians should weigh the relatively modest benefits of formoterol as-needed against the benefits of single inhaler therapy and the potential danger of long-term use of long-acting beta-agonists in some patients. We did not find evidence to recommend changes to guidelines that suggest that long-acting beta 2 -agonists should be given only to patients already taking inhaled corticosteroids.

There was insufficient information reported from children in the included trials to come to any conclusion on the safety or efficacy of formoterol as relief medication for children with asthma.

\section{PLAIN LANGUAGE SUMMARY}

\section{Formoterol versus short-acting beta-agonists as symptom relief for adults and children with asthma}

Short-acting beta-agonists are traditionally used to ease symptoms when people experience wheezing and breathlessness during asthma exacerbations. Formoterol is a bronchodilator that works quickly to relieve symptoms and the effect lasts longer. We are interested in whether there are any benefits or disadvantages associated with using formoterol instead of more traditional treatments to relieve symptoms.

We found eight trials involving a total of 22,604 patients. We found that taking formoterol reduced the risk of having an exacerbation that was treated with oral corticosteroids, but none of the other benefits from taking formoterol were statistically significant. Guidelines suggest that long-acting beta-agonists should be given only to patients already taking an inhaled corticosteroid.

We could not find enough trials conducted in children to reach a conclusion on the benefits and harms in children, so we do not recommend using the results to make recommendations on treatment of children with asthma. 


\begin{tabular}{|c|c|c|c|c|c|c|}
\hline 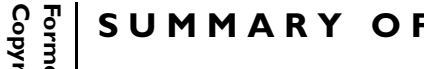 & F F INDINGS & T H E & COM & S O N [Explana & & \\
\hline Formoterol versus short-a & 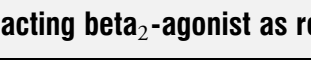 & elief medication for asthma & & & & \\
\hline $\begin{array}{l}\text { Patient or population: Pati } \\
\text { Settings: International stuc } \\
\text { Intervention: Formoterol v }\end{array}$ & $\begin{array}{l}\text { tients with asthma } \\
\text { dies } \\
\text { versus short-acting beta }{ }_{2}-c\end{array}$ & gonist & & & & \\
\hline Outcomes & Illustrative comparative & risks* $(95 \%$ CI) & Relative effect & No of Participants & Quality of the evidence & Comments \\
\hline 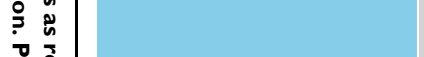 & Assumed risk & Corresponding risk & & & & \\
\hline 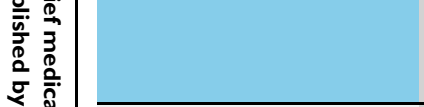 & Control & $\begin{array}{l}\text { Formoterol versus short- } \\
\text { acting beta }_{2} \text {-agonist }\end{array}$ & & & & \\
\hline $\begin{array}{l}\text { Patients with an exac- } \\
\text { erbation requiring hospi- } \\
\text { talisation } \\
\text { Follow up: mean } 30 \\
\text { weeks }\end{array}$ & 16 per $1000^{1}$ & $\begin{array}{l}13 \text { per } 1000 \\
(11 \text { to } 17)\end{array}$ & $\begin{array}{l}\text { OR } 0.84 \\
(0.67 \text { to } 1.04)\end{array}$ & $\begin{array}{l}22236 \\
\text { (7 studies) }\end{array}$ & $\begin{array}{l}\oplus \oplus \oplus \bigcirc \\
\text { moderate }^{2}\end{array}$ & \\
\hline $\begin{array}{l}\text { Patients with an ex- } \\
\text { acerbation requiring a } \\
\text { course of oral corticos- } \\
\text { teroids } \\
\text { Follow up: mean } 30 \\
\text { weeks }\end{array}$ & 117 per $1000^{1}$ & $\begin{array}{l}101 \text { per } 1000 \\
\text { (93 to 108) }\end{array}$ & $\begin{array}{l}\text { OR } 0.84 \\
(0.77 \text { to } 0.91)\end{array}$ & $\begin{array}{l}21591 \\
\text { (6 studies) }\end{array}$ & $\begin{array}{l}\oplus \oplus \oplus \bigcirc \\
\text { moderate }^{3}\end{array}$ & $\begin{array}{l}\text { Exacerbations } \\
\text { were still significantly re- } \\
\text { duced when results were } \\
\text { confined to double-blind } \\
\text { studies }\end{array}$ \\
\hline $\begin{array}{l}\text { Fatal serious adverse } \\
\text { events (all-cause) } \\
\text { Follow up: mean } 30 \\
\text { weeks }\end{array}$ & 1 per $1000^{1}$ & $\begin{array}{l}1 \text { per } 1000 \\
(1 \text { to } 2)\end{array}$ & $\begin{array}{l}\text { OR } 1.08 \\
\text { (0.51 to 2.3) }\end{array}$ & $\begin{array}{l}21629 \\
\text { (5 studies) }\end{array}$ & $\begin{array}{l}\oplus \oplus \bigcirc \bigcirc \\
\text { low }^{4}\end{array}$ & $\begin{array}{l}\text { There were few deaths } \\
\text { in participants on either } \\
\text { medication. A larger trial } \\
\text { is unlikely to be powered } \\
\text { to detect a difference in } \\
\text { mortality }\end{array}$ \\
\hline
\end{tabular}




\begin{tabular}{|c|c|c|c|c|c|c|}
\hline $\begin{array}{l}\text { Patients with a seri- } \\
\text { ous adverse event (all } \\
\text { cause) } \\
\text { Follow-up: mean } 30 \\
\text { weeks }\end{array}$ & 35 per $1000^{1}$ & $\begin{array}{l}33 \text { per } 1000 \\
(29 \text { to } 38)\end{array}$ & $\begin{array}{l}\text { OR } 0.94 \\
(0.81 \text { to } 1.08)\end{array}$ & $\begin{array}{l}22538 \\
\text { (7 studies) }\end{array}$ & $\begin{array}{l}\oplus \oplus \bigcirc \bigcirc \\
\text { low }^{2,3}\end{array}$ & \\
\hline $\begin{array}{l}\text { Patients with a serious } \\
\text { adverse event (asthma } \\
\text { related) } \\
\text { Follow up: mean } 30 \\
\text { weeks }\end{array}$ & 14 per $1000^{1}$ & $\begin{array}{l}13 \text { per } 1000 \\
(10 \text { to } 16)\end{array}$ & $\begin{array}{l}\text { OR } \mathbf{0 . 9 1} \\
(0.72 \text { to } 1.15)\end{array}$ & $\begin{array}{l}21986 \\
\text { (6 studies) }\end{array}$ & $\begin{array}{l}\oplus \oplus \bigcirc \bigcirc \\
\text { low }^{2,3}\end{array}$ & \\
\hline $\begin{array}{l}\text { Withdrawals (any rea- } \\
\text { son) } \\
\text { Follow up: mean } 30 \\
\text { weeks }\end{array}$ & 72 per $1000^{1}$ & $\begin{array}{l}\mathbf{8 0} \text { per } 1000 \\
\text { (73 to } 87)\end{array}$ & $\begin{array}{l}\text { OR } 1.12 \\
(1.02 \text { to } 1.24)\end{array}$ & $\begin{array}{l}22541 \\
\text { (7 studies) }\end{array}$ & $\begin{array}{l}\oplus \oplus \bigcirc \bigcirc \\
\text { low }^{3,5}\end{array}$ & $\begin{array}{l}\text { Confining the analysis } \\
\text { to double-blind studies } \\
\text { changed the direction of } \\
\text { the treatment effect }\end{array}$ \\
\hline
\end{tabular}

*The basis for the assumed risk (e.g. the median control group risk across studies) is provided in footnotes. The corresponding risk (and its $95 \%$ confidence interval) is based on the assumed risk in the comparison group and the relative effect of the intervention (and its $95 \% \mathrm{Cl}$ ).

Cl: Confidence interval; OR: Odds ratio;

GRADE Working Group grades of evidence

High quality: Further research is very unlikely to change our confidence in the estimate of effect.

Moderate quality: Further research is likely to have an important impact on our confidence in the estimate of effect and may change the estimate.

Low quality: Further research is very likely to have an important impact on our confidence in the estimate of effect and is likely to change the estimate.

Very low quality: We are very uncertain about the estimate.

${ }^{1}$ Mean control event rate.

Confidence interval includes the possibility of benefit or harm.

${ }^{3}$ One study was open-label.

${ }^{4}$ Few participants died which led to wide confidence intervals.

5 There was significant heterogeneity in this outcome, probably due to the open-label design and population-wide nature of RELIEF. 


\section{B A C K G R O U N D}

\section{Description of the condition}

There is currently no universally accepted definition of the term asthma. This is in part due to an overlap of symptoms with other diseases such as chronic bronchitis but is also due to the probable existence of more than one underlying pathophysiological process. There are, for example, wide variations in the age of onset, symptoms, triggers, association with allergic disease and the type of inflammatory cell infiltrate seen in patients diagnosed with asthma (Miranda 2003). Patients with all forms and severity of disease will typically have intermittent symptoms of cough, wheeze and/ or breathlessness. Underlying these symptoms there is a process of variable, at least partially reversible, airway obstruction, airway hyper-responsiveness and chronic inflammation.

\section{Description of the intervention}

People with persistent asthma can use preventer therapy (usually low-dose inhaled corticosteroid (ICS)) to maintain symptom control, improve lung function and reduce emergency care requirement (Adams 2008). However, when symptoms deteriorate, reliever medication in the form of short-acting beta 2 -agonists such as salbutamol or terbutaline (BTS/SIGN 2008) is required. An alternative long-acting beta 2 -agonist (LABA), formoterol, has the potential to be used as reliever therapy, as it has an onset of action that is as fast as salbutamol and terbutaline, unlike another longacting beta 2 -agonist, salmeterol (Palmqvist 2001).

\section{How the intervention might work}

Formoterol can be used to relieve bronchospasm and may have advantages over using salbutamol and terbutaline as reliever medication, since the benefit lasts for 12 hours (Lötvall 2008). Concerns have been raised about the use of regular salmeterol and formoterol in asthma, in particular where it is used without a regular inhaled corticosteroid, in relation to the possible increased risk of severe adverse events and asthma-related death (Cates 2008; Cates 2008a; Walters 2007).

\section{Why it is important to do this review}

The only large worldwide safety study on formoterol has been done on its use as relief medication (RELIEF 2003). This trial was not considered in a previous systematic review which evaluated the use of regular formoterol compared to placebo (Cates 2008a) rather than as a relief medication; the review showed that there was an increased risk of serious adverse events in patients on maintenance formoterol. Although the use of single inhaler therapy has been advocated as a new approach to asthma care (Barnes 2007), and as way of increasing compliance with inhaled corticosteroids (Delea 2008; Sovani 2008), others have pointed out limitations in the current research evidence on formoterol alone in children and adults with less severe asthma (Bisgaard 2003; Lipworth 2007). Although there are existing reviews on formoterol combined with an inhaled corticosteroid used for maintenance and relief of asthma symptoms (Cates 2009; Cates 2009a), there is currently no systematic review of the efficacy and safety of formoterol alone as reliever therapy.

\section{O B J E C T IVES}

To assess the efficacy and safety of formoterol as reliever therapy in asthma in comparison to short-acting beta 2 -agonists for relief of symptoms.

\section{MET HO D S}

\section{Criteria for considering studies for this review}

\section{Types of studies}

Randomised trials of parallel-group design of at least 12 weeks duration were included in the review. Open-label and doubleblind study designs were eligible. We excluded cross-over trials.

\section{Types of participants}

Adults and children with a diagnosis of asthma. We accepted trialist-defined asthma and recorded both the definition of asthma used in the studies and the entry criteria. Studies on patients with acute asthma or exercise-induced bronchospasm were not included.

\section{Types of interventions}

\section{Eligible treatment group intervention}

Studies which assessed the effects of using any dose of formoterol for the relief of asthma symptoms were eligible. Other maintenance treatments were allowed provided they were not part of the asneeded randomisation regime.

\section{Eligible control group treatment}

The control groups for the studies in this review consisted of shortacting beta 2 -agonists (salbutamol or terbutaline) for relief of symptoms. Studies that compared different doses of formoterol, or different delivery devices or propellants were not included. 


\section{Types of outcome measures}

\section{Primary outcomes}

1. Patients with exacerbations requiring hospitalisation

2. Patients with exacerbations requiring oral corticosteroids

3. Fatal serious adverse events (all-cause)

4. Non-fatal serious adverse events (all-cause and asthmarelated)

\section{Secondary outcomes}

1. Diary card morning and evening peak expiratory flow (PEF)

2. Clinic spirometry (FEV1)

3. Symptoms/symptom-free days

4. Nocturnal awakenings

5. Quality of life

\section{Search methods for identification of studies}

\section{Electronic searches}

We identified trials using the Cochrane Airways Group Specialised Register of trials, which is derived from systematic searches of bibliographic databases including the Cochrane Central Register of Controlled Trials (CENTRAL), MEDLINE, EMBASE, CINAHL, AMED and PsycINFO, and handsearching of respiratory journals and meeting abstracts (please see the Airways Group Module for further details). All records in the Specialised Register coded as 'asthma' were searched using the following terms: (formoterol or eformoterol or oxis or foradil) and (relie* or "as need*” or as-need* or prn)

\section{Searching other resources}

We contacted the manufacturer in order to confirm data and to establish whether other unpublished or ongoing studies are available for assessment. We handsearched clinical trial websites (www.clinicalstudyresults.org; www.clinicaltrials.gov; www.fda.gov) and the clinical trial websites of the manufacturer of formoterol (www.astrazenecaclinicaltrials.com).

\section{Data collection and analysis}

\section{Selection of studies}

Following electronic literature searches, two review authors (CC and EJW) independently selected articles on the basis of title and/ or abstract for full-text scrutiny. We agreed a list of articles to be retrieved and subsequently assessed each study to determine whether it was a secondary publication of a primary study publication and whether the study met the entry criteria of the review.

\section{Data extraction and management}

We extracted information from each study for the following characteristics:

1. Design (description of randomisation, blinding, number of study centres and location, number of study withdrawals).

2. Participants (N, mean age, age range of the study, baseline lung function, $\%$ on maintenance ICS or ICS/LABA combination and average daily dose of steroid (beclomethasone dipropionate equivalent), entry criteria).

3. Intervention (type and dose of component ICS and LABA, control limb dosing schedule, intervention limb dose adjustment schedule, inhaler device, study duration and run-in)

4. Outcomes (type of outcome analysis, outcomes analysed).

\section{Assessment of risk of bias in included studies}

We assessed the risk of bias in the included studies as either high, low or unclear using the Cochrane Collaboration's 'Risk of bias' tool (Higgins 2008) and the following headings 1) sequence generation; 2) allocation concealment; 3) blinding; 4) incomplete outcome data; 5) selective outcome reporting; and 6) other bias.

\section{Measures of treatment effect}

We extracted data, where possible, for each of the outcomes listed above from the trial publication(s) and contacted trialists and manufacturers for further information. We entered exacerbations into the meta-analysis by subtype (hospitalisation and courses of oral steroids), rather than as a composite outcome and figures were calculated from other outcome data and verified by the manufacturer where necessary. We considered serious adverse events separately as fatal and non-fatal events.

\section{Unit of analysis issues}

We used or requested data from the trial sponsors that were reported with patients (rather than events) as the unit of analysis for the primary outcomes. Some patients suffer more than one exacerbation over the course of a study and these events are not independent. Where it was not possible to obtain these data, we entered events and discussed any effects this may have on the results of individual meta-analyses.

\section{Dealing with missing data}

The proportion of randomised patients who provided data for the main outcomes was reported and compared with the number of patients with events in each outcome category. 


\section{Assessment of heterogeneity}

We measured statistical variation between combined studies by the $\mathrm{I}^{2}$ statistic (Higgins 2003). We investigated possible causes of any heterogeneity that were found.

\section{Assessment of reporting biases}

We inspected funnel plots to see if there was evidence of publication bias where there were enough studies to render this meaningful. Where possible we compared the outcomes suggested in the trial protocol with those reported for each trial.

\section{Data synthesis}

We combined data with Review Manager 5 (RevMan 2008) using a fixed-effect mean difference (calculated as a weighted mean difference) for continuous data variables, and a fixed-effect odds ratio for dichotomous variables. For the primary outcomes of exacerbations and serious adverse events we calculated a number needed to treat (NNT) (benefit or harm) for the different levels of risk as represented by control group event rates over a specified time period using the pooled odds ratio and its confidence interval using an on-line calculator, Visual Rx. The Peto odds ratio was used for subgroup analysis as there were no important differences in the results when compared to the Mantel-Haenszel odds ratio and Peto allows for a test of subgroup interaction to be calculated in Review Manager 5.

We constructed 'Summary of findings' tables for the four primary outcomes.

\section{Subgroup analysis and investigation of heterogeneity}

We intended to pool data from adults and children separately and requested separate information on outcomes in order to compare adults and children using subgroup analysis, but it was not possible to obtain separate results on children from the trials that included adults and children. We also intended to perform subgroup analyses based on use of maintenance inhaled corticosteroids and longacting beta 2 -agonists, and asthma severity.

\section{Sensitivity analysis}

We conducted sensitivity analyses on the basis of risk of bias in studies and methods of data analysis (OR, RR, RD with fixed and random-effects models).

\section{R E S U L T S}

\section{Description of studies}

See: Characteristics of included studies; Characteristics of excluded studies.

\section{Results of the search}

We conducted an all-years search of the Airways Group Register in February 2010. There was no restriction on language of the search. The search yielded a total of 140 references. We examined the reference list of titles and abstracts and assessed each reference against eligibility criteria. We retrieved full text articles of 35 references. We identified 8 included studies and 6 excluded studies and complete agreement was reached between authors. A search of www.astrazenecaclinicaltrials.com yielded five study reports corresponding to five of the included clinical trials and an AstraZeneca Briefing Document was found on the FDA website. We asked AstraZeneca if there were any additional study reports or references to studies that they had sponsored, but none were returned.

\section{Included studies}

Full details can be found in the Characteristics of included studies tables.

\section{Participants}

A total of 22,604 participants were randomised to eight eligible studies (Ind 2002; Jain 2004; Rabe 2006; RELIEF 2003; SD-0370714; SD-037-0716; Tattersfield 2001; Villa 2002). The largest trial was RELIEF 2003 with 17,862 participants, whilst Rabe 2006 had 2281 participants and the remaining six trials had between 60 and 675 participants. The trials were also of different lengths with a mean duration of 29.5 weeks; three trials were 12 months long (Rabe 2006; SD-037-0714; SD-037-0716), three were six months long (Jain 2004; RELIEF 2003; Villa 2002) and two were three months long (Ind 2002; Tattersfield 2001).

Two trials (Ind 2002; Tattersfield 2001) were conducted in adults, one in children (Villa 2002), four trials (Rabe 2006; RELIEF 2003; SD-037-0714; SD-037-0716) were conducted in adults and children and it was unclear in what population Jain 2004 was conducted. Participants with a range of different asthma severities across studies were enrolled. The largest study (RELIEF 2003) allowed any severity of asthma, whilst Rabe 2006 allowed moderate to severe, Tattersfield 2001 and Villa 2002 allowed mild-moderate, SD-037-0714 participants had mild asthma and SD-037-0716 had intermittent asthma.

\section{Interventions}

All eight trials compared formoterol as-needed with one of two short-acting beta 2 -agonists (Table 1 ) and most were designed to show that formoterol was as safe as the short-acting beta 2 -agonist in question. Formoterol was compared with terbutaline in six trials (Ind 2002; Rabe 2006; SD-037-0714; SD-037-0716; Tattersfield 2001; Villa 2002) and salbutamol in two trials (Jain 2004; RELIEF 
2003). In addition to the as-needed medications, participants in some trial were permitted to take, or required to be on, additional maintenance medication (Table 1). Although this review addresses formoterol used as-needed rather than as maintenance, three trials ( Ind 2002; Rabe 2006; Tattersfield 2001) reported mean daily doses of 1.9 to 3.9 puffs a day (8.5 to $17.5 \mu \mathrm{g}$ ) which is of the order of recommended maintenance formoterol doses $(12 \mu \mathrm{g}$ twice daily, BNF).

All participants in Ind 2002 were on maintenance formoterol as a study medication in addition to constant dose of inhaled corticosteroids and randomised as-needed formoterol or terbutaline. All participants in Rabe 2006 were originally on inhaled corticosteroids and were then moved to budesonide/formoterol at a dose on which they were symptomatic in addition to randomised formoterol or terbutaline. Participants in SD-037-0714 were on inhaled corticosteroids at different but constant doses and were not permitted other long-acting beta 2 -agonists. Participants in Tattersfield 2001 stayed on the same dose of inhaled corticosteroids or other maintenance medications and participants in Villa 2002 were on inhaled corticosteroids, disodium cromoglycate or nedocromil at a constant dose. Any ordinary asthma medication apart from relievers was permitted in RELIEF 2003, and subgroup data by background medication were reported for serious adverse events, discontinuations due to serious adverse events and exacerbations. Patients in RELIEF 2003 were able to have their prescriptions for maintenance medication changed in response to changing asthma. Participants in SD-037-0716 were not on maintenance medication. It was not stated whether patients were on any sort of maintenance medication in the abstract located for Jain 2004.

RELIEF 2003 was the only trial to employ pressurised metered dose inhalers; formoterol was delivered via dry powder inhaler in all countries whereas salbutamol was delivered via a dry powder inhaler in six countries and by pressurised metered dose inhaler in 18 countries. The other six trials employed dry powder inhalers for both formoterol and short-acting beta 2 -agonist.

Participants were instructed to take their relief inhalers as needed and to tell the investigators if they took more than 10 puffs in a day (Rabe 2006) or more than 12 puffs (Tattersfield 2001) or more than 12 puffs in adults and eight puffs in children (RELIEF 2003).

Usage of relief inhalers was an inclusion criteria in six of the studies, this was not stated by Jain 2004 and not a criteria for RELIEF 2003. To be eligible for randomisation, participants in Ind 2002 had to have taken between two and five puffs of terbutaline per day during run-in, those in Tattersfield 2001 had to have taken between three and eight puffs a day on at least seven days in the run-in period. Patients in the other trials took fewer inhalations; those in Rabe 2006 had to have used relief medication on five out of seven days; participants in SD-037-0714 participants used fewer than four inhalations per day on at least three occasions per week; SD-037-0716 used their inhalers on between two and six occasions during run-in and participants in Villa 2002 used an average of at least one puff per day during the run-in period. Asthma severity in the studies is summarised in Table 2 with details of the duration and number of centres for each study.

Patients were withdrawn from the studies if their daily use of relief medication exceeded certain thresholds. These were eight puffs per day $(\mathrm{N}=2), 10$ puffs $(\mathrm{N}=1)$ and 12 puffs $(\mathrm{N}=2)$.

\section{Outcomes}

The primary outcomes for the studies did not necessarily match ours because the aim of individual trials was to show that formoterol is as effective as short-acting beta 2 -agonists and there was some variation across studies. Time until first asthma exacerbation as the primary outcome was used in four studies (Rabe 2006; RELIEF 2003; Tattersfield 2001; Villa 2002). Peak expiratory flow was employed as the primary outcome by SD-037-0714 and SD-037-0716 whilst Ind 2002 used serum potassium levels, ECG, vital signs, lung function and adverse events.

However, data for our primary outcomes were well-reported and so we were able to use these in our review. Patients with exacerbations requiring hospitalisation were reported in seven studies; patients with exacerbations requiring oral corticosteroids in six studies and fatal serious adverse events in four studies and non-fatal serious adverse events in seven studies. Our secondary outcomes were also well-reported. We did not find separate details of results from children in those studies that included both adults and children.

\section{Excluded studies}

Full details can be found in the Characteristics of excluded studies tables.

\section{Risk of bias in included studies}

A summary of the risk of bias in the included studies is shown in Figure 1 
Figure I. Methodological quality summary: review authors' judgements about each methodological quality item for each included study.

\begin{tabular}{|c|c|c|c|c|c|c|c|}
\hline & 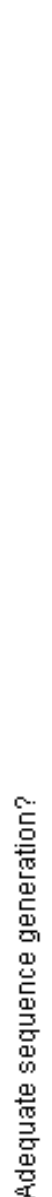 & 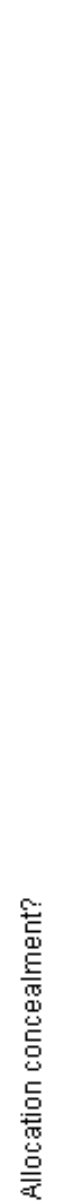 & 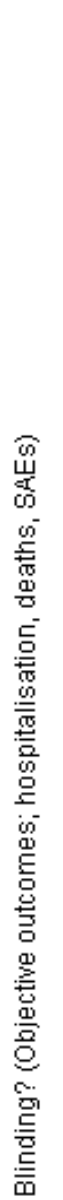 & 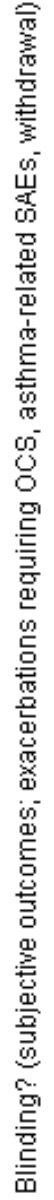 & 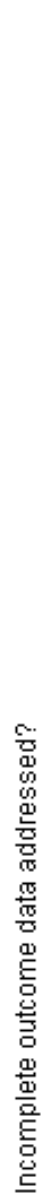 & 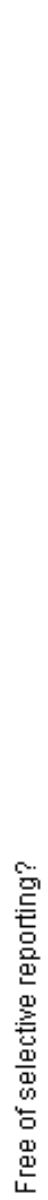 & 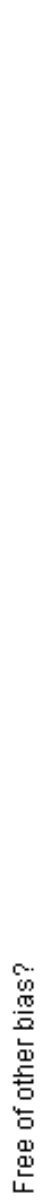 \\
\hline Ind 2002 & + & + & + & + & $?$ & + & + \\
\hline Jain 2004 & $?$ & $?$ & $?$ & $?$ & $?$ & $?$ & \\
\hline Rabe 2006 & + & + & + & + & + & + & + \\
\hline RELIEF 2003 & + & $\odot$ & + & $?$ & + & + & + \\
\hline SD-037-0714 & + & $\odot$ & + & $?$ & + & + & + \\
\hline SD-037-0716 & + & + & + & $?$ & + & + & + \\
\hline Tattersfield 2001 & + & + & + & $?$ & + & + & $?$ \\
\hline Villa 2002 & + & + & + & + & + & $?$ & \\
\hline
\end{tabular}




\begin{abstract}
Allocation
All eight trials were described as randomised. Three trials (Rabe 2006; RELIEF 2003; Tattersfield 2001) gave detailed descriptions of satisfactory sequence generation and allocation concealment. Four trials did not provide such clear descriptions (Ind 2002; SD-037-0714; SD-037-0716; Villa 2002); however the sponsor provided details of adequate randomisation. Jain 2004 was described as randomised with no further details, and so sequence generation and allocation concealment remains at unclear risk of bias.
\end{abstract}

\section{Blinding}

Six trials overall were described as double-blind; neither patient nor investigator knew to which as-needed medication an individual was randomised. Blinding was preserved by delivering medications via identical inhalers. Three studies provided detailed descriptions of how the patients were blinded (Ind 2002; Rabe 2006; Tattersfield 2001) and the sponsors provided suitable descriptions of the blinding for the remaining three trials (SD-037-0714; SD-037-0716; Villa 2002). In three trials (Tattersfield 2001; SD-037-0714; SD-037-0716) the blinding was lifted in the case of a serious adverse event and so was judged as unclear risk of bias for the subjective outcomes.

RELIEF 2003 was an open-label study that did not attempt to blind the participants or investigators. This is unlikely to have affected objective outcome measures (hospitalisations, all-cause serious adverse events, deaths) which was judged to be at low risk of bias. However, the open-label design may have affected subjective outcomes and was judged to be at unclear risk of bias for this domain. Bias may result from having unblinded investigators, who may consciously or subconsciously make different decisions on whether to give a patients a course of oral corticosteroids or in judging whether or not a serious adverse event was related to asthma. In addition, knowledge of the study drug may affect a patient's decision to withdraw from the study.

\section{Incomplete outcome data}

Six trials were judged to be at low risk of bias from incomplete outcome reporting (Rabe 2006; RELIEF 2003; SD-037-0714; SD-037-0716; Tattersfield 2001; Villa 2002) and all trials were analysed on an intention-to-treat basis. Five trials reported reasons for withdrawals and were balanced between treatment arms (Rabe 2006; RELIEF 2003; SD-037-0714; SD-037-0716; Tattersfield 2001). Although Villa 2002 did not provide reasons for withdrawal, it was judged to be low risk of bias because the numbers of withdrawals were similar to those in other trials in this review and balanced between treatment arms (Table 3). Ind 2002 was judged to be at unclear risk of bias due to incomplete outcome data, because although numbers of withdrawals were reported it was not clear how many withdrawals corresponded to each treatment arm. Jain 2004 was judged to be at unclear risk of incomplete outcome data bias because the number of withdrawals, if any, was not disclosed in the abstract.

Additionally, Ind 2002 reported only run-in data for FEV1 or PEF and stated that this remained unchanged throughout the treatment period. We felt it was unlikely that the mean and standard deviation stayed constant throughout this whole period, but since there were no data to enter into the meta-analysis this judgement did not effect the outcome of our meta-analysis.

\section{Selective reporting}

Six trials were judged to be of low risk of selective outcome reporting bias (Ind 2002; Rabe 2006; RELIEF 2003; SD-037-0714; SD-037-0716; Tattersfield 2001). Villa 2002 was judged to be at unclear risk of selective outcome reporting bias because some key data (PEF, number of inhalations, night-time awakenings, days restricted activity, FEV1, quality of life, adverse events) relevant to our study or stipulated as outcomes in the study report, were missing from the study report. Jain 2004 was also at unknown risk of bias in this domain but since there was a single abstract published and we cannot be sure of the missing results.

\section{Other potential sources of bias}

Villa 2002 was judged to be at high risk of publication bias because the study has only been published as a study report and an abstract and therefore lacks information on study characteristics and outcome data. Jain 2004 was also at high risk of publication bias since it was published as a single abstract. Although it is debatable whether trials that have only been reported as abstract should be included in Cochrane systematic reviews, these two trials were small and did not have a meaningful effect on the results of the meta-analysis and so they remain in the review as a record.

Exacerbations were assessed subjectively by the investigator in some of the trials (Ind 2002; Rabe 2006; RELIEF 2003; SD-0370714; SD-037-0716; Tattersfield 2001), although a drop in PEF of $>30 \%$ was also considered an exacerbation by Ind 2002 and Tattersfield 2001. None of the trials reported explicit definitions of asthma-related serious adverse events, and they used patient reported asthma aggravated events where described.

All the trials apart from Jain 2004 were sponsored by AstraZeneca.

\section{Effects of interventions}

See: Summary of findings for the main comparison Formoterol versus short-acting beta2-agonist as relief medication for asthma 
There was only one trial conducted in children (Villa 2002, N = 552), and trials that were conducted in children and adults did not provide separate paediatric data. Therefore there was insufficient paediatric data presented to merit a full subgroup analysis. We also found that subgroup analysis by asthma severity was not feasible due to the overlap in asthma severities in the various trials.

In the majority of the meta-analyses, heterogeneity was not encountered. The $\mathrm{I}^{2}$ statistic is only mentioned in the discussion below when it is not equal to zero. All meta-analyses were compared with both the Peto odds ratio and/or the Mantel-Haenszel random-effects model. There was no difference in these sensitivity analyses except for withdrawals.

\section{Primary outcomes}

\section{Patients with an exacerbation requiring hospitalisation}

Overall seven trials provided data on hospital admissions for 22,236 participants (Ind 2002; Jain 2004; Rabe 2006; RELIEF 2003; SD-037-0714; SD-037-0716; Villa 2002). There were fewer hospitalisations in participants on formoterol than in those on short-acting beta 2 -agonist (OR $0.84 ; 95 \%$ CI 0.67 to 1.04 ), however this was not statistically significant (Figure 2). Sixteen patients on short-acting beta 2 -agonists out of 1000 had hospitalisations over 30 weeks, compared to 13 (95\% CI 11 to 17) out of 1000 in patients on formoterol but this confidence interval includes the possibility that there is no difference between the treatments.

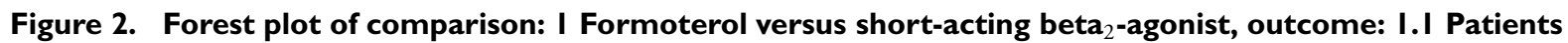
with an exacerbation requiring hospitalisation.

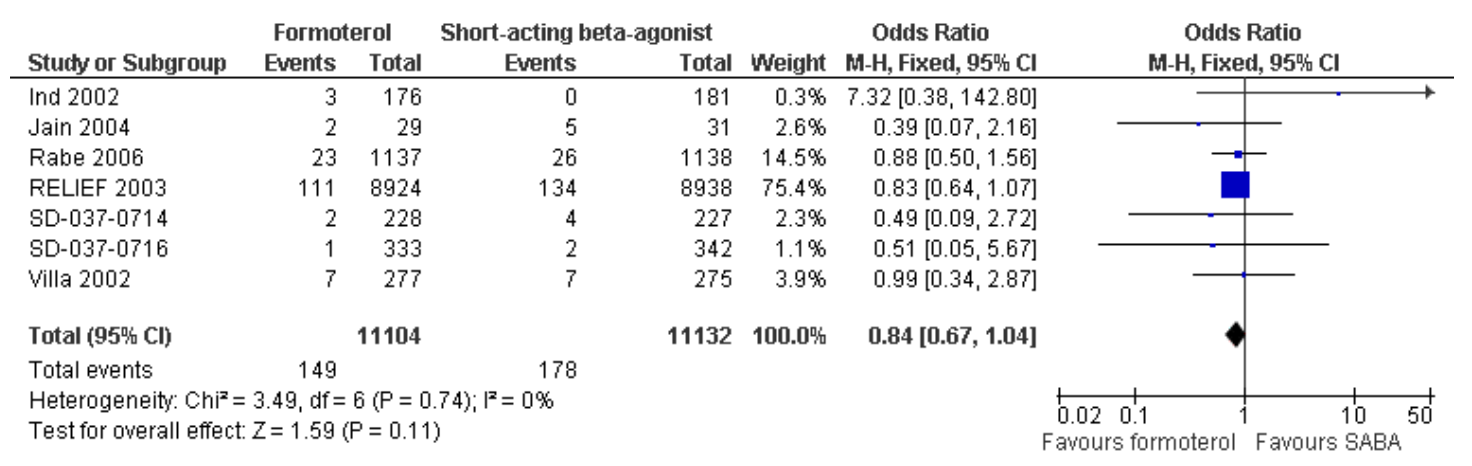

Rabe 2006 reported serious adverse events reported as asthma and this was used as a proxy measure for hospitalisations. Two trials (Ind 2002; Jain 2004) reported events rather than the number of participants experiencing an event, which could lead to tighter confidence intervals than representative of the true treatment effect if any participants had experienced more than one hospital admission.

\section{Patients with an exacerbation requiring a course of oral} corticosteroids

Six trials contributed data on exacerbations requiring a course of oral corticosteroids for 21,591 participants (Ind 2002; Jain 2004; Rabe 2006; RELIEF 2003; SD-037-0716; Villa 2002). There were fewer exacerbations requiring a course of oral corticosteroids in patients of formoterol than those on short-acting beta2-agonists (OR 0.84; 95\% CI 0.77 to 0.91 ) which was a statistically significant difference (Figure 3; Analysis 1.2). In patients on short-acting beta 2 -agonists, 117 people out of 1000 had exacerbations requiring oral corticosteroids over 30 weeks, compared to 101 (95\% CI 93 to 108) out of 1000 for patients on formoterol as-needed (Figure 4). 
Figure 3. Forest plot of comparison: I Formoterol versus short-acting beta 2 -agonist, outcome: I.2 Patients with an exacerbation requiring a course of oral corticosteroids.

\begin{tabular}{|c|c|c|c|c|c|c|c|c|}
\hline \multirow[b]{2}{*}{ Study or Subgroup } & \multicolumn{2}{|c|}{ Formoterol } & \multicolumn{2}{|c|}{ Short-acting beta-agonist } & \multirow[b]{2}{*}{ Weight } & \multirow{2}{*}{$\begin{array}{c}\text { Odds Ratio } \\
\text { M-H, Fixed, 95\% Cl }\end{array}$} & \multirow{2}{*}{\multicolumn{2}{|c|}{$\begin{array}{c}\text { Odds Ratio } \\
\text { M-H, Fixed, 95\% } \mathrm{Cl}\end{array}$}} \\
\hline & Events & Total & Events & Total & & & & \\
\hline Ind 2002 & 34 & 176 & 39 & 181 & $2.7 \%$ & $0.87[0.52,1.46]$ & & \\
\hline Jain 2004 & 9 & 29 & 13 & 31 & $0.8 \%$ & $0.62[0.22,1.80]$ & & \\
\hline Rabe 2006 & 170 & 1137 & 216 & 1138 & $16.2 \%$ & $0.75[0.60,0.94]$ & $\rightarrow-$ & \\
\hline RELIEF 2003 & 830 & 8924 & 959 & 8938 & $76.8 \%$ & $0.85[0.77,0.94]$ & $\square$ & \\
\hline SD-037-0716 & 17 & 333 & 12 & 342 & $1.0 \%$ & $1.48[0.70,3.15]$ & & \\
\hline Tattersfield 2001 & 21 & 182 & 31 & 180 & $2.4 \%$ & $0.63[0.35,1.14]$ & & \\
\hline Total $(95 \% \mathrm{Cl})$ & & 10781 & & 10810 & $100.0 \%$ & $0.84[0.77,0.91]$ & $\boldsymbol{\varphi}$ & \\
\hline Total events & 1081 & & 1270 & & & & & \\
\hline $\begin{array}{l}\text { Heterogeneity: } \mathrm{Chi}^{2}= \\
\text { Test for overall effect }\end{array}$ & $\begin{array}{l}4.50, \mathrm{df}= \\
Z=4.070\end{array}$ & $\begin{array}{l}5(P=0 \\
P<0.00\end{array}$ & $\begin{array}{l}.48) ;\left.\right|^{2}=0 \% \\
\text { 101) }\end{array}$ & & & & $\begin{array}{l}0.5 \\
\text { ormoterol }\end{array}$ & $\begin{array}{rr}1 & 2 \\
\text { Favours }\end{array}$ \\
\hline
\end{tabular}

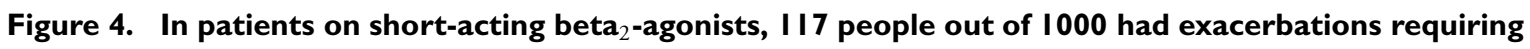
oral corticosteroids over 30 weeks, compared to $10 \mathrm{I}$ (95\% Cl 93 to I08) out of 1000 for patients on formoterol as-needed.

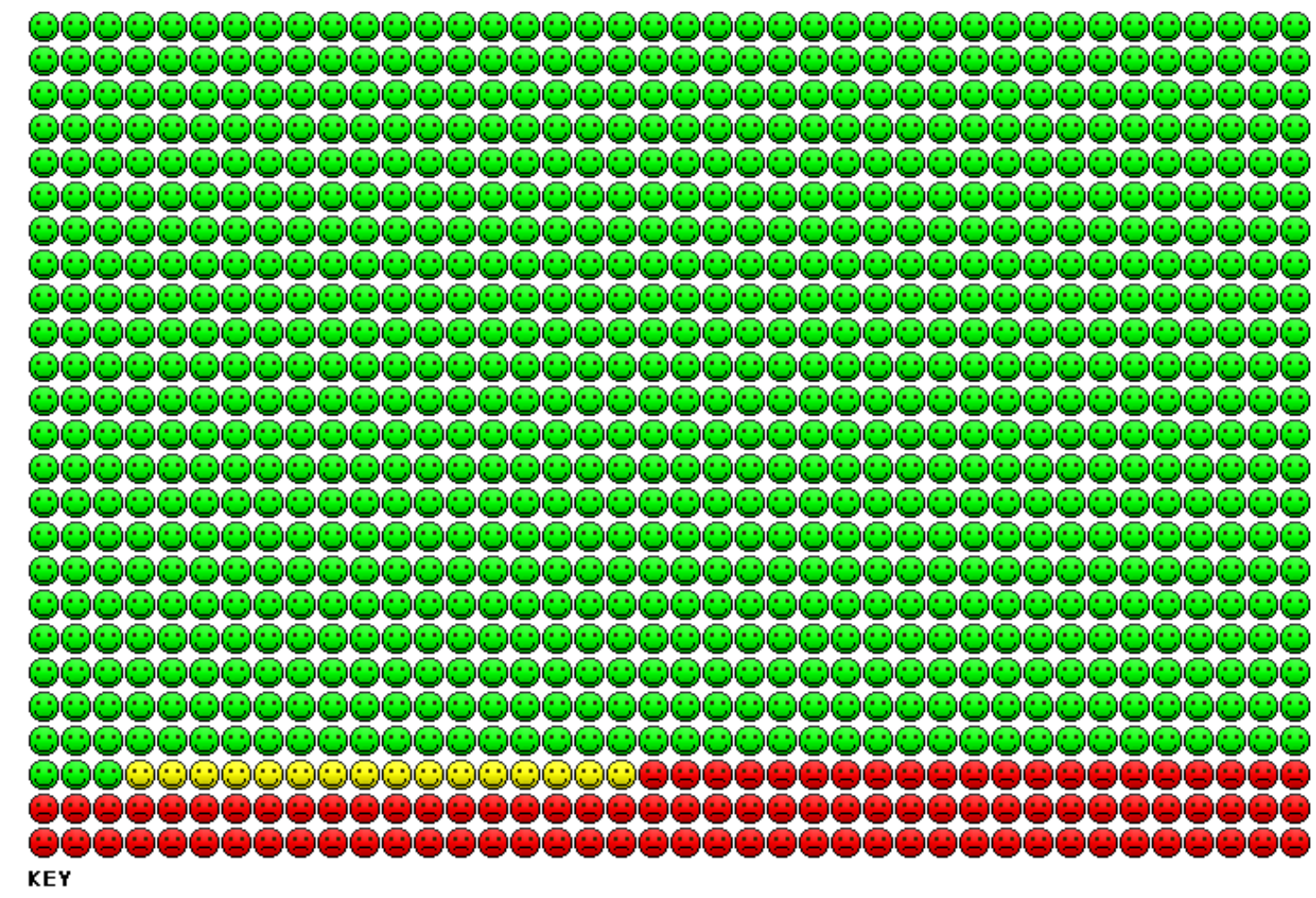
Q Good outcome
Bad outcome
(9) Better with treatment
Better with control 
We calculated data for RELIEF 2003 by subtracting hospitalisations from severe exacerbations, but the reduction in exacerbations is still significant when data from RELIEF 2003 are excluded. Jain 2004 reported events rather than the number of participants experiencing an event, which could again lead to an over-precise estimate of the treatment effect, however performing a sensitivity analysis by removing this study did not significantly alter the estimate of treatment effect. Data were provided by the sponsors for Rabe 2006.

\section{Exacerbations requiring a course of oral corticosteroids in relation to maintenance medication use}

Four studies contributed to a subgroup analysis for exacerbations requiring a course of oral corticosteroids according to maintenance inhaled corticosteroid use (Figure 5; Analysis 2.1) on 3669 patients. Patients in Ind 2002, Rabe 2006 and Tattersfield 2001 were on maintenance inhaled corticosteroids as either a randomised dose of budesonide/formoterol (Rabe 2006) or non-randomised inhaled corticosteroids at a stable dose (Ind 2002; Tattersfield 2001). Among these patients, there were fewer exacerbations requiring a course of oral corticosteroids in patients on formoterol than those on short-acting beta2-agonists (Peto OR 0.75; 95\% CI 0.62 to 0.91 ) which was a statistically significant improvement. There was only one trial that we could ascertain was conducted in patients who were not taking inhaled corticosteroids (SD-037-0716) and there was no statistically significant difference in exacerbations requiring oral corticosteroids for this study (Peto OR $1.47 ; 95 \%$ CI 0.70 to 3.10 ). Although these treatment effects were in opposite directions, there was no significant difference in the test for subgroup differences $\left(\mathrm{Chi}^{2}=2.94, \mathrm{df}=1(\mathrm{P}=0.09)\right)$ so a relationship between exacerbations requiring oral corticosteroids and maintenance inhaled corticosteroids was neither proved or disproved.

Figure 5. Forest plot of comparison: 2 Formoterol versus short-acting beta 2 -agonist (background ICS use), outcome: 2.I Patients with an exacerbation requiring a course of oral corticosteroids.

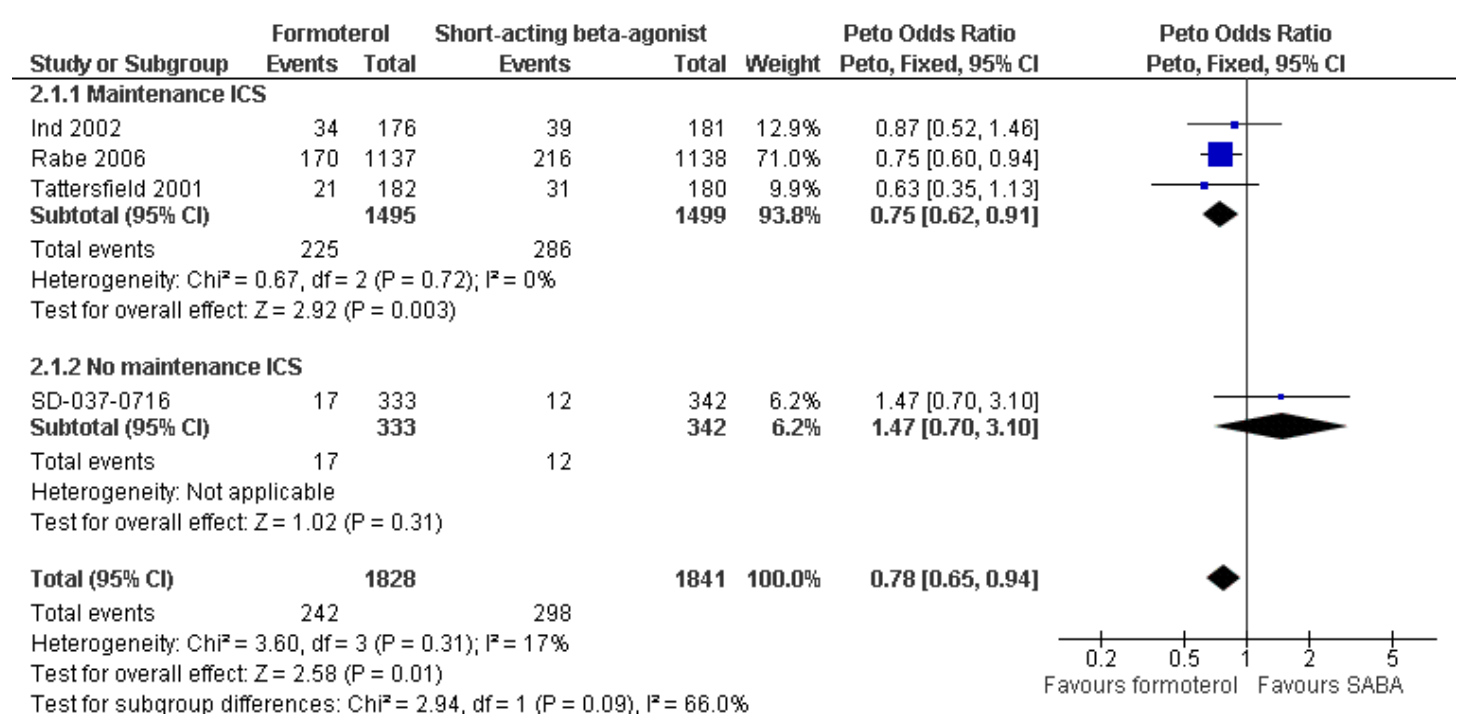

\section{Fatal serious adverse events (all-cause)}

Five trials on 21,629 participants provided mortality data (Figure 6, Analysis 1.3). There was one death per 1000 people on both formoterol and on short-acting beta 2 -agonists used for relief of symptoms (OR 1.08; 95\% CI 0.51 to 2.30). These trials are underpowered to detect a difference in mortality rates and an unfeasibly large trial would be required to do this. 
Figure 6. Forest plot of comparison: I Formoterol versus short-acting beta 2 -agonist, outcome: I.3 Fatal serious adverse events (all-cause).

\begin{tabular}{|c|c|c|c|c|c|c|c|}
\hline \multirow[b]{2}{*}{ Study or Subgroup } & \multicolumn{2}{|c|}{ Formoterol } & \multicolumn{2}{|c|}{ Short-acting beta-agonist } & \multirow[b]{2}{*}{ Weight } & \multirow{2}{*}{$\begin{array}{c}\text { Odds Ratio } \\
\text { M-H, Fixed, 95\% Cl }\end{array}$} & \multirow{2}{*}{$\begin{array}{c}\text { Odds Ratio } \\
\text { M-H, Fixed, 95\% Cl }\end{array}$} \\
\hline & Events & Total & Events & Total & & & \\
\hline Rabe 2006 & 1 & 1137 & 2 & 1138 & $15.4 \%$ & $0.50[0.05,5.52]$ & \\
\hline RELIEF 2003 & 13 & 8924 & 11 & 8938 & $84.6 \%$ & $1.18[0.53,2.64]$ & \\
\hline SD-037-0714 & 0 & 228 & 0 & 227 & & Not estimable & \\
\hline SD-037-0716 & 0 & 333 & 0 & 342 & & Not estimable & \\
\hline Tattersfield 2001 & 0 & 182 & 0 & 180 & & Not estimable & \\
\hline Total $(95 \% \mathrm{Cl})$ & & 10804 & & 10825 & $100.0^{\%} \%$ & $1.08[0.51,2.30]$ & \\
\hline Total events & 14 & & 13 & & & & \\
\hline $\begin{array}{l}\text { Heterogeneity: } \mathrm{Chi}^{2}= \\
\text { Test for overall effect }\end{array}$ & $\begin{array}{l}0.45, \mathrm{df}= \\
Z=0.20(\end{array}$ & $\begin{array}{l}1(P=0 \\
P=0.84\end{array}$ & $50) ;\left.\right|^{2}=0 \%$ & & & & $\begin{array}{ccccc}1 & 1 & 1 & 1 \\
0.05 & 0.2 & 1 & 5 & 20 \\
\text { Favours formoterol } & \text { Favours SABA }\end{array}$ \\
\hline
\end{tabular}

There were three deaths in Rabe 2006, one on formoterol asneeded and two on terbutaline as-needed, but none of these were judged by the study investigator to be related to the study drug and none were reported as asthma. In RELIEF 2003, there were 13 deaths in patients on formoterol as-needed of which three were judged to be related to asthma, and 11 deaths in patients on salbutamol as-needed, of which two were deemed related to asthma.

\section{Patients with a serious adverse event (all-cause)}

Seven trials provided data on serious adverse events in 22,538 participants (Ind 2002; Rabe 2006; RELIEF 2003; SD-037-0714; SD-037-0716; Tattersfield 2001; Villa 2002). Overall there were fewer serious adverse events from any cause in patients on formoterol than in patients on short-acting beta 2 -agonists but this difference did not reach statistical significance (OR 0.94; 95\% CI
0.81 to 1.08 ), see Figure 7 (Analysis 1.4). In patients on shortacting beta 2 -agonists, 35 people out of 1000 had serious adverse events (all-cause) over 30 weeks, compared to 33 (95\% CI 29 to 38) out of 1000 in patients on formoterol but the confidence interval includes the possibility that there is no difference between the treatments. There was a small amount of statistical heterogeneity $\left(\mathrm{I}^{2}=9 \%\right)$. Data were entered into the meta-analysis as the number of patients experiencing one or more serious adverse events in six cases (Rabe 2006; RELIEF 2003; SD-037-0714; SD-037-0716; Tattersfield 2001; Villa 2002) and as the total number of events in Ind 2002, although performing a sensitivity analysis without this trial did not significantly alter the estimate of the treatment effect. Three trials reported patients experiencing more than one exacerbation (Rabe 2006; RELIEF 2003; Villa 2002) and further details can be found in the Characteristics of included studies.

Figure 7. Forest plot of comparison: I Formoterol versus short-acting beta 2 -agonist, outcome: I.4 Patients with a serious adverse event (all-cause).

\begin{tabular}{|c|c|c|c|c|c|c|c|}
\hline \multirow[b]{2}{*}{ Study or Subgroup } & \multicolumn{2}{|c|}{ Formoterol } & \multicolumn{2}{|c|}{ Short-acting beta-agonist } & \multirow[b]{2}{*}{ Weight } & \multirow{2}{*}{$\begin{array}{c}\text { Odds Ratio } \\
\text { M-H, Fixed, 95\% Cl }\end{array}$} & \multirow{2}{*}{$\begin{array}{c}\text { Odds Ratio } \\
\text { M-H, Fixed, 95\% } \mathrm{Cl}\end{array}$} \\
\hline & Events & Total & Events & Total & & & \\
\hline Ind 2002 & 7 & 176 & 1 & 181 & $0.2 \%$ & $7.46[0.91,61.24]$ & $\longrightarrow$ \\
\hline Rabe 2006 & 55 & 1137 & 65 & 1138 & $16.1 \%$ & $0.84[0.58,1.21]$ & \\
\hline RELIEF 2003 & 278 & 8924 & 299 & 8938 & $75.3 \%$ & $0.93[0.79,1.10]$ & \\
\hline SD-037-0714 & 12 & 228 & 13 & 227 & $3.2 \%$ & $0.91[0.41,2.05]$ & \\
\hline SD-037-0716 & 6 & 333 & 6 & 342 & $1.5 \%$ & $1.03[0.33,3.22]$ & \\
\hline Tattersfield 2001 & 0 & 182 & 3 & 180 & $0.9 \%$ & $0.14[0.01,2.71]$ & $\longleftarrow$ \\
\hline Villa 2002 & 15 & 277 & 11 & 275 & $2.7 \%$ & $1.37[0.62,3.05]$ & \\
\hline Total (95\% Cl) & & 11257 & & 11281 & $100.0 \%$ & $0.94[0.81,1.08]$ & \\
\hline Total events & 373 & & 398 & & & & \\
\hline $\begin{array}{l}\text { Heterogeneity: } \mathrm{Chi}^{2} \\
\text { Test for overall effec }\end{array}$ & $\begin{array}{l}6.58, \mathrm{df}= \\
Z=0.89\end{array}$ & $\begin{array}{l}6(P=0 \\
P=0.37\end{array}$ & 7) $36 ;\left.\right|^{2}=9 \%$ & & & & 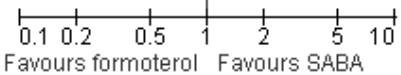 \\
\hline
\end{tabular}

Serious adverse events (all-cause) in relation to maintenance medication use
All seven trials provided data and could be analysed by subgroup according to maintenance inhaled corticosteroids, or lack thereof 
(Figure 8, Analysis 2.2). Five trials were conducted in patients who were on maintenance inhaled corticosteroids (Ind 2002; Rabe 2006; SD-037-0714; Tattersfield 2001; Villa 2002) and separate data were available for this outcome in RELIEF 2003. There were fewer all-cause serious adverse events in patients randomised to formoterol who were also on maintenance inhaled corticosteroids, although this difference did not reach statistical significance (OR $0.91 ; 95 \%$ CI 0.78 to 1.06 ). There was a small amount of statistical heterogeneity found $\left(\mathrm{I}^{2}=25 \%\right)$. In patients who were not taking inhaled corticosteroids (RELIEF 2003; SD-037-0716) there were fewer serious adverse events in patients on short-acting beta 2 -agonists although this difference did not reach statistical significance (OR 1.14; 95\% CI 0.77 to 1.69). Although there was a difference in the direction of the treatment effects for each subgroup, the test for subgroup differences $\left(\mathrm{Chi}^{2}=1.17, \mathrm{df}=1(\mathrm{P}=0.28)\right) \mathrm{did}$ not show a significant interaction between maintenance inhaled corticosteroids and all-cause serious adverse events.

Figure 8. Forest plot of comparison: 2 Formoterol versus short-acting beta 2 -agonist (background ICS use), outcome: 2.2 Patients with a serious adverse event (all-cause).

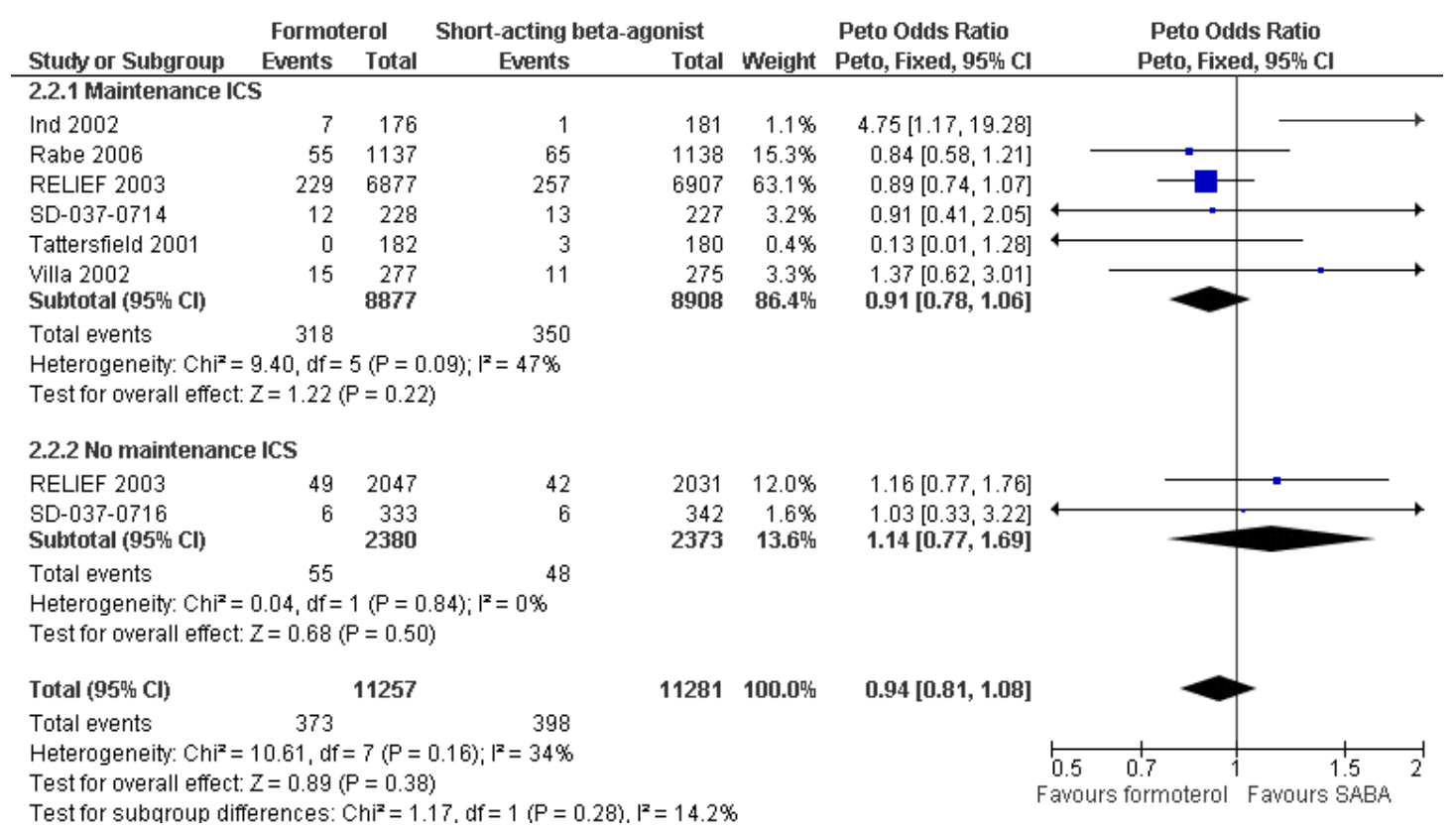

We also performed a subgroup analysis on the basis of maintenance long-acting beta2-agonist use or lack thereof (Analysis 3.1). Three trials contributed data for patients who were taking maintenance long-acting beta 2 -agonists (Ind 2002; Rabe 2006; RELIEF 2003). There were fewer all-cause serious adverse events in patients on formoterol compared to those on short-acting beta 2 -agonist, although this did not reach statistical significance (OR 0.84; 95\% CI 0.68 to 1.03 ). In patients who were not taking long-acting beta $_{2}$-agonist as maintenance, there was no significant difference in serious adverse events in those on formoterol or short-acting beta $_{2}$-agonists (OR 1.06; $95 \%$ CI 0.86 to 1.30 ). The test for subgroup difference did not show a statistically significant difference in the treatment effects in patients on background long-acting beta 2 -agonists compared to those on none $\left(\mathrm{Chi}^{2}=2.44, \mathrm{df}=1(\mathrm{P}\right.$
$=0.12)$.

Patients with a serious adverse event (asthma-related)

Six trials reported asthma-related serious adverse events in 21,986 participants (Ind 2002; Rabe 2006; RELIEF 2003; SD-037-0714; SD-037-0716; Tattersfield 2001). These trials showed fewer asthma-related serious adverse events in patients on formoterol than in patients on short-acting beta2-agonists, although this difference did not reach statistical significance (OR 0.91; 95\% CI 0.72 to 1.15$)$, see Figure 9. In patients on short-acting beta 2 -agonists, 14 people out of 1000 had asthma-related serious adverse events over 30 weeks, compared to 13 (95\% CI 10 to 16) out 
of 1000 for patients on formoterol as-needed. Although number of events was reported, the sponsors provided data on the number of patients experiencing an event from three trials (Ind 2002; SD-037-0714; SD-037-0716).

Figure 9. Forest plot of comparison: I Formoterol versus short-acting beta 2 -agonist, outcome: I.5 Patients with a serious adverse event (asthma-related).

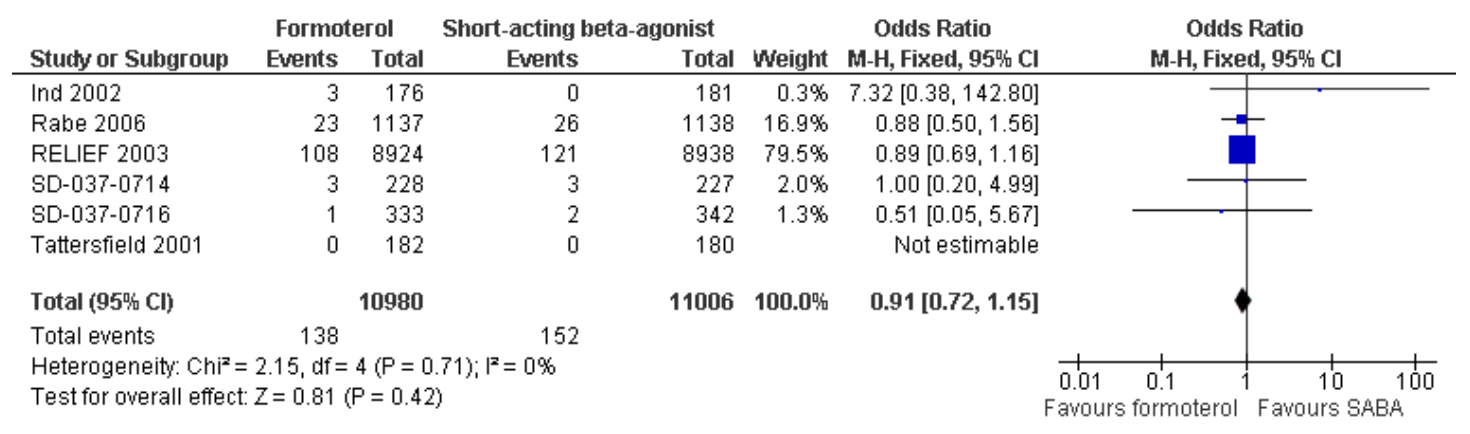

\section{Secondary outcomes}

\section{Peak expiratory flow (PEF)}

Patients on formoterol showed a greater improvement in morning PEF than those on short-acting beta 2 -agonists (MD $3.88 \mathrm{~L} / \mathrm{min}$; $95 \%$ CI 1.29 to 6.46 ), and this was a small but statistically significant result (Analysis 1.6). There was a small amount of statistical heterogeneity $\left(I^{2}=17 \%\right)$. Again, patients on formoterol showed a greater improvement in evening PEF than those on short-acting beta 2 -agonists (MD 2.05 L/min; 95\% CI -0.50 to 4.60), however this difference was not statistically significant (Analysis 1.7).

\section{Fixed expiratory flow in one second (FEVI)}

One study reported a modest change in FEV1 in litres (Rabe 2006). There was an improvement in FEV1 of $30 \mathrm{~mL}$ (MD 0.03 L; $95 \%$ CI 0.00 to 0.06 ).

Three studies reported change in \% predicted FEV1 (SD-0370714; SD-037-0716; Tattersfield 2001). These studies favoured formoterol (MD 0.61\%; $95 \%$ CI -0.49 to 1.71 ), but this difference was not statistically significant. There was a large amount of heterogeneity in this result $\left(\mathrm{I}^{2}=85 \%\right)$. There was clinical heterogeneity in the baseline values which might explain the statistical heterogeneity observed; two studies had mean baseline FEV1 \% predicted close to $100 \%$ (SD-037-0714; SD-037-0716), whilst
Tattersfield 2001 had a lower mean FEV1 \% predicted at baseline (74\%).

\section{Symptoms (day-time)}

Five studies provided information on symptoms (Rabe 2006; RELIEF 2003; SD-037-0714; SD-037-0716; Tattersfield 2001), but the unit of analysis varied. Rabe 2006 reported change from run-in on an asthma symptom score scale from zero to six. Participants in Rabe 2006 on formoterol showed an improvement in symptoms of -0.58 and participants on terbutaline showed an improvement of -0.57 which did not result in a significant difference between the two treatments (MD 0.1; 95\% CI -0.05 to 0.07) (Analysis 1.8). SD-037-0714, SD-037-0716 and Tattersfield 2001 reported symptom scores on a scale of zero to four, but there was no significant difference between scores.

\section{Nocturnal awakenings}

Two studies reported nocturnal awakenings. Rabe 2006 reported no significant difference in the adjusted mean change from run-in; patients on formoterol reported an improvement of $-14.0 \%$ and patients on formoterol a $-13.5 \%$ reduction in awakenings (MD 0.60; $95 \%$ CI -2.25 to 1.05 ). Tattersfield 2001 also reported no significant difference in nocturnal awakenings (MD 0.00, 95\% CI -0.10 to 0.10$)$.

\section{Quality of life}

Tattersfield 2001 reported data for quality of life, using the Asthma 
Quality of Life Questionnaire (AQLQ) measured on a scale of zero to seven. There was an improvement of 0.41 units in patients on formoterol as-needed and 0.17 units in patients on terbutaline asneeded which was a statistically significant difference (MD 0.24; $95 \%$ CI 0.09 to 0.39 ), but the minimally important difference to the individual is 0.5 units.

\section{Withdrawals (any reason)}

Seven trials provided data for the number of withdrawals (Ind 2002; Rabe 2006; RELIEF 2003; SD-037-0714; SD-037-0716; Tattersfield 2001; Villa 2002). The numbers of withdrawals varied between $4.8 \%$ and $13 \%$ per treatment arm across all the studies (Table 3). There were more withdrawals in patients on formoterol compared to short-acting beta2-agonists (OR fixed-effect 1.12; 95\% CI 1.02 to 1.24 ) and this was statistically significant. However, there is statistical heterogeneity present which merits further discussion $\left(\mathrm{I}^{2}=71 \%\right)$.

This meta-analysis is dominated by RELIEF 2003, a trial in which the majority of withdrawals were from patients on formoterol, in contrast to the other studies that have more withdrawals in patients on short-acting beta 2 -agonists. The population-wide, openlabel design of RELIEF 2003 in comparison to the double-blind nature of the other trails may account for part of this difference. Performing sensitivity analysis by removing trials at high risk of bias for this outcome, which in this case is RELIEF 2003, gives a statistically significant result in favour of short-acting beta2-agonists (OR 0.80; 95\% CI 0.67 to 0.96).

The RELIEF 2003 trialists report a statistically significant treatment interaction for asthma-related discontinuations by inhaler type. In the countries where both medications were delivered by dry powder inhalers, the numbers of discontinuations due to asthma-related adverse events were balanced across both treatments $(28(1.1 \%)$ in patients on formoterol and $24(1.0 \%)$ in patients on salbutamol, $\mathrm{P}=0.61)$. However in countries where salbutamol was delivered by pressurised metered dose inhaler there were more discontinuations due to asthma-related adverse events in patients on formoterol (61 (1\%) compared to $25(0.4 \%), \mathrm{P}<$ 0.001). Discontinuation may therefore have been related to the change from metered dose inhaler to dry powder delivery for patients who used formoterol as a reliever in RELIEF 2003.

\section{DISCUSSION}

There were eight included studies, of which two were reported only as an abstract. Participants in five of the studies were on a maintenance inhaled corticosteroid (one with maintenance formoterol plus and inhaled corticosteroid and one on a budesonide/ formoterol combined inhaler) and patients in the largest trial were allowed to take any normal medication. The short-acting beta2agonist was terbutaline in six trials and salbutamol in two. Most of the studies employed dry powder inhalers. All the studies apart from a large open-label effectiveness study were double-blind. Despite these differences we judged that it was possible to look at the major endpoints laid out in our protocol.

\section{Summary of main results}

Asthma exacerbations and serious adverse events showed a direction of treatment effect favouring formoterol, of which one primary outcome reached statistical significance (exacerbations requiring a course of oral corticosteroids). In patients on short-acting beta 2 -agonists, 117 people out of 1000 had exacerbations requiring oral corticosteroids over 30 weeks, compared to 101 ( $95 \%$ CI 93 to 108) out of 1000 for patients on formoterol as-needed. There were fewer exacerbations requiring a course of oral corticosteroids in the subgroup of patients taking maintenance inhaled corticosteroids on formoterol as-needed than those on short-acting beta 2 -agonists. Although study participants not on background inhaled steroids appeared to be at a greater risk of exacerbations than those on inhaled steroids (Analysis 2.1), the subgroup difference did not reach statistical significance. We remain uncertain as to the nature and strength of the relationship between concurrent inhaled steroid exposure and the risk of exacerbations requiring oral corticosteroids. There were few deaths in the studies and consequently there were wide confidence intervals around the risk of death. In the control group one person out of 1000 died over 30 weeks, compared to one ( $95 \%$ CI 1 to 3) out of 1000 for the active treatment group.

\section{Overall completeness and applicability of evidence}

There were few studies of formoterol versus short-acting beta 2 agonists as-needed conducted solely in children and a lack of separate paediatric data in other trials. Therefore in order to apply the results of this systematic review to children, one would have to assume that children have the same response to these drugs as adults. A review of maintenance formoterol in patients who were not taking maintenance inhaled corticosteroids showed an increase in adverse events in serious adverse events in children compared to adults (Cates 2008a). Our results therefore cannot be safely applied to children.

There were limited data for subgroups according to background maintenance inhaled corticosteroid or long-acting beta 2 -agonist therapy.

There was a broad range of asthma severities included in the trials and it was not possible to separate outcome data by asthma severity, so we cannot apply evidence in this review to populations with specific asthma severities.

Participants in three studies (Rabe 2006; Tattersfield 2001; Villa 2002) demonstrated reversibility to terbutaline, whereas participants were not tested for reversibility in four trials (Ind 2002; 
RELIEF 2003; SD-037-0714; SD-037-0716) and we are not sure whether or not reversibility was tested in Jain 2004. This might limit the applicability of our findings.

\section{Quality of the evidence}

Most of the studies we found were good quality trials in terms of randomisation and blinding, although Jain 2004 was reported as a single abstract the author did not provide more information. Removing this trial from the meta-analysis did not markedly affect the results. Although there is a risk of detection bias from RELIEF 2003 being open-label, particularly with respect to subjective outcomes, excluding it from the meta-analyses did not actually change the direction or statistical significance of the pooled treatment effects. Its impact on the estimate of withdrawals was more substantial, with the direction of the result moving in favour of short-acting beta 2 -agonist.

The studies and also our systematic review were underpowered to detect a difference in mortality. Because of the low incidence of death in asthma clinical trials, an unfeasibly large trial would be required to demonstrate a difference in mortality (Rodrigo 2010; Wijesinghe 2009).

The studies employed different as-needed medications, inhalers and background medication. In addition the major trial was openlabel in comparison to the other trials which were double-blind. The considerable differences between the trials may make the combined results harder to interpret.

\section{Summary of findings table}

We downgraded evidence for the subjective outcomes (exacerbations requiring oral corticosteroids, asthma-related serious adverse events and withdrawals) because we felt that these were subject to bias due to the large open-label trial. Although this trial might be more like "real life", a double-blind trial of the same size might change the results of the review. Exacerbations leading to hospitalisations was downgraded because the confidence interval included the possibility of no difference in treatment effect. Deaths were downgraded twice for imprecision due to the sparsity of events and the width of the confidence interval. Withdrawals was downgraded by an additional point because there was significant heterogeneity for this outcome.

\section{Potential biases in the review process}

The review process was protected from bias by following a prepublished protocol. We minimised bias by assessing studies independently and resolving differences of opinion by discussion. Data extraction was also performed in duplicate. We consulted the manufacturer of formoterol and asked if they could identify other published or unpublished reports of their trials, and provide unpublished data and clarification of data that we calculated from available information. We only performed subgroup analyses that were specified a priori in the protocol.

\section{Agreements and disagreements with other studies or reviews}

Of current concern in asthma management is whether treatment with regular long-acting beta 2 -agonists such as formoterol masks deterioration in asthma due to non-control of underlying inflammation with inhaled corticosteroids (Pavord 2009). The average dose used of formoterol as-needed (8.5 to $17.5 \mu \mathrm{g}$ ) was of the order of the recommended maintenance formoterol dosage (12 $\mu \mathrm{g}$ twice daily). Patients on formoterol "as-needed" may therefore be subject to increased risks of serious adverse events if they are not taking regular inhaled corticosteroids. It is not recommended to take formoterol without taking inhaled corticosteroids (BTS/SIGN 2008; Cates 2008a; Cates 2009b; FDA website).

Patients tend to increase their reliever therapies rather than their inhaled corticosteroids when their asthma worsens. Therefore, a more pertinent clinical question than whether formoterol asneeded is better than short-acting beta 2 -agonists as-needed, at least in high-income countries, is whether single inhaler therapy is superior to separate inhalers. The studies described in this review were designed by the sponsors to demonstrate whether formoterol as a reliever is as safe and effective as short-acting beta 2 -agonists, and this allowed development of single inhaler therapy for the maintenance and relief of symptoms.

\section{A U THORS, CONCLUSIONS}

\section{Implications for practice}

In adults, formoterol was similar to short-acting beta 2 -agonists when used as a reliever and showed a reduction in the number of exacerbations requiring a course of oral corticosteroids. Clinicians should weigh the relatively modest benefits of formoterol as-needed against the benefits of single inhaler therapy and the potential danger of long-term use of long-acting beta 2 -agonists in some patients. We did not find evidence to recommend changes to guidelines that suggest that long-acting beta2-agonists should be given only to patients already taking inhaled corticosteroids.

There was insufficient information reported from children in the included trials to come to any conclusion on the safety or efficacy of formoterol as relief medication for children with asthma.

\section{Implications for research}

Further research is required to clarify the safety and efficacy of formoterol as a reliever in children. 
Assessing differences in mortality rates in a study comparing formoterol to short-acting beta 2 -agonists is hampered by the requirement for very large numbers of patients. A double-blind trial of the same size as RELIEF 2003 may offer further, more reliable, information on the differences in efficacy in relation to adverse events and exacerbations although it is difficult to recommend that a trial of this nature should be conducted in patients who are not already receiving maintenance inhaled corticosteroids. It is also questionable whether there would be sufficient interest in the results of such a study, in view of the advent of maintenance and reliever therapy with combined inhaled corticosteroid and formoterol inhalers.

\section{ACKNOWLEDGEMENTS}

We are grateful to Susan Hansen for assistance with designing the search strategy. We also thank Joe Gray from AstraZeneca for providing data and information on studies and Toby Lasserson for editing our review and ensuring that our editing reflected peer review comments.

\section{RE FER E N C E S}

\section{References to studies included in this review}

\section{Ind 2002 \{published data only\}}

Ind P, Borszormenyi Nagy G, Pietinalho A, Shiner R, Villasante C, Brander R, et al.Formoterol 4.5 microgram used as needed via turbuhaler was as safe and well tolerated as terbutaline $0.5 \mathrm{mg}$. European Respiratory Society, Oct 913; Madrid, Spain. 1999:1086.

Ind PW, Villasante C, Shiner RJ, Pietinalho A, Boszormenyi NG, Soliman S, et al.Safety of formoterol by Turbuhaler as reliever medication compared with terbutaline in moderate asthma. European Respiratory Journal 2002;20(4):859-66.

Jain 2004 \{published data only\}

Jain A, Raghuram J. Randomized controlled study of the safety and efficacy of PRN formoterol compared to PRN albuterol for the management of asthma. American Thoracic Society 100th International Conference, May 2126, Orlando. 2004:B36 Poster G17.

Rabe 2006 \{published data only\}

Rabe KF, Atienza T, Magyar P, Larsson P, Jorup C, Lalloo UG. Effect of budesonide in combination with formoterol for reliever therapy in asthma exacerbations: a randomised controlled, double-blind study. Lancet 2006;368(9537): 744-53.

SD-039-0734. Efficay of Symbicort ${ }^{\circledR}$ Turbuhaler ${ }^{\circledR} 160 /$ $4.5 \mu \mathrm{g}$ as needed versus $\mathrm{Oxis}{ }^{\circledR} 4.5 \mu \mathrm{g}$ as needed and Bricanyl ${ }^{\circledR} 0 / 4 \mathrm{mg}$ as needed in adults and adolescents with asthma receiving Symbicort ${ }^{\circledR}$ Turbuhaler ${ }^{\circledR}$ 160/4.5 $\mu \mathrm{g}$ twice daily as maintenance treatment. A 12-month, randomised, double-blind, parallel group, active-controlled, phase IIIB, multi-centre study. AstraZeneca Study Report.

RELIEF 2003 \{published data only\}

SD-037-0699. AstraZeneca Study Report.

Lindgren B, Sears MR, Campbell M, Villasante C, Huang $\mathrm{S}$, Lindh A, et al.Cost-effectiveness of formoterol and salbutamol as asthma reliever medication in Sweden and in Spain. International Journal of Clinical Practice 2005;59(1): 62-8.

Lindgren B, Sears MR, Campbell M, Villasante C, Huang $\mathrm{S}$, Lindh A, et al.Total costs according to reliever use of formoterol turbuhaler in asthma: results from the RELIEF worldwide randomised effectiveness study, stratified by maintenance medication levels. European Respiratory Journal 2002;20(Suppl 38):43s.

Lindgren B, Sears MR, Compbell M, Villasante C, Huang $\mathrm{S}$, Lindh A, et al.Cost-effectiveness of formoterol turbuhaler versus salbutamol as reliever therapy in asthma: results from the RELIEF worldwide randomised effectiveness study. European Respiratory Journal. 2002:P389, 43s.

Pauwels RA, Campbell M, Villasante C, Huang S, Lindh A, Petermann W. Formoterol turbuhaler compared with salbutamol as reliever medication in asthma: outcomes from the RELIEF study in patients across different severities and age groups. European Respiratory Journal. 2002; Vol. 20 (Suppl 38):P395, 45s.

Pauwels RA, Campbell M, Villasante C, Huang S, Lindh A, Petermann W, et al.Formoterol turbuhaler compared with salbutamol as reliever medication in asthma: a worldwide, randomised, effectiveness trial (RELIEF Study). European Respiratory Society Annual Congress. 2002:P391.

Pauwels RA, Compbell M, Villasante C, Huang S, Lindh A, Petermann W, et al.Formoterol turbuhaler compared with salbutamol as reliever medication in asthma: an exploratory analysis of the RELIEF study in patients using formoterol as maintenance therapy. European Respiratory Journal. 2002: P392.

Pauwels RA, Sears MR, Campbell M, Villasante C, Huang $\mathrm{S}$, Lindh A, et al.Formoterol as relief medication in asthma: a worldwide safety and effectiveness trial. European Respiratory Journal 2003;22(5):787-94.

Sears MR, Pauwels RA, Campbell M, Villasante C, Huang $\mathrm{S}$, Lindhl A, et al.Safety of formoterol turbuhaler when used as a reliever therapy in asthma (the RELIEF study). European Respiratory Society Annual Congress 2002. 2002; Vol. 20(Suppl 38):P393.

Sears MR, Pauwels RA, Campbell M, Villasante C, Uang SH, Lindh A, et al.Safety of formoterol turbuhaler used as reliever in asthma: relationship with age and baseline treatment including regular long-acting beta 2 -agonists (the RELIEF study). European Respiratory Journal. 2002; Vol. 20(Suppl 38):P394, 44S. 


\section{SD-037-0714 \{published data only\}}

A 12-month comparison of Oxis ${ }^{\circledR}$ (formoterol) Turbuhaler ${ }^{\circledR}$ and Bricanyl ${ }^{\circledR}$ (terbutaline) Turbuhaler ${ }^{\circledR}$ both used as needed in patients with asthma on antiinflammatory treatment. AstraZeneca Study Report Vol. SD-037-0714.

Chuchalin A, Kasl M, Bengtsson T, Nihlen U, Rosenborg J. Formoterol used as needed in patients with intermittent or mild persistent asthma. Respiratory Medicine 2005;99(4): 461-70.

\section{SD-037-0716 \{published data only\}}

A 12-month comparison of $\mathrm{Oxis}{ }^{\circledR}$ (formoterol) Turbuhaler ${ }^{\circledR}$ and Bricanyl® (terbutaline) Turbuhaler ${ }^{\circledR}$ both used as needed in patients with asthma not using antiinflammatory treatment. AstraZeneca Study Report Vol. SD-037-0716.

Chuchalin A, Kasl M, Bengtsson T, Nihlen U, Rosenborg J. Formoterol used as needed in patients with intermittent or mild persistent asthma. Respiratory Medicine 2005;99(4): 461-70.

Chuchalin A, Makarova I, Bergqvist P. As-needed formoterol has an improved safety profile compared with asneeded terbutaline in mild intermittent asthma. European Respiratory Journal. 2003; Vol. 22(Suppl 45):P1571.

\section{Tattersfield 2001 \{published data only\}}

Berggren F, Ekstrom T. A cost-effectiveness study comparing the as-needed use of formoterol Oxis and terbutaline Bricanyl in patients with moderate to severe asthma. Respiratory Medicine 2001;95(9):753-8.

Berggren F, Ekstrom T. Formoterol was more cost effective in a modelling study than terbutaline in as needed treatment of patients with moderate asthma. European Respiratory Society. 1999:P2293.

Berggren F, Svenson K, Rolnick M S, Alexander M, Mintz S. Twice-daily formoterol Oxis ${ }^{\circledR}$ turbuhaler is more cost-effective than twice-daily salmeterol or as-needed salbutamol. American Thoracic Society Meeting. 2001 Stahl E, Postma DS, Svensson K, Tattersfield AE, Eivindson A, Schreurs A, et al.Formoterol used as needed improves health-related quality of life in asthmatic patients uncontrolled with inhaled corticosteroids. Respiratory Medicine 2003:96(9):1061-6.

Tattersfield AE, Lofdahl CG, Postma DS, Eivindson A, Schreurs AG, Rasidakis A, et al.Comparison of formoterol and terbutaline for as-needed treatment of asthma: a randomised trial. Lancet 2001;357(9252):257-61.

Villa 2002 \{published data only\}

SD-037-0695. AstraZeneca Study report 2001. Villa J, Kuna P, Egner J, Brader R. Safety of formoterol reliever therapy compared with terbutaline in asthmatic children taking anti-inflammatory therapy. European Respiratory Society Annual Congress. 2002:P2739. Villa J, Kuna P, Egner J, Brander R. A 6-month comparison of the safety profiles of formoterol (Oxis ${ }^{\circledR}$ turbuhaler ${ }^{\circledR}$ ) as needed and terbutaline (Bricanyl® turbuhaler $\left.{ }^{\circledR}\right)$ as needed in asthmatic children on anti-inflammatory medication.
American Journal of Respiratory and Critical Care Medicine 2002;165(8 Suppl):A746.

\section{References to studies excluded from this review}

\section{Bisgaard 2005 \{published data only\}}

Bisgaard H, Hultquist C. Efficacy and safety of budesonide/ formoterol (Symbicort) Turbuhaler®as Single Therapy in patients with mild-moderate asthma. Comparison with Symbicort Turbuhaler and Pulmicort ${ }^{\circledR}$ Turbuhaler as maintenance therapy, both complemented with Bricanyl ${ }^{\circledR}$ Turbuhaler (STAY). AstraZeneca Study Report 2005, issue SD-039-0673.

Boskovska 2001 \{published data only\}

Boskovska MI, Gerovski BD, Dimitrovski TM, Arbutina SD, Jovkovsa Kaeva BM. Efficacy of long-term formoterol therapy vs as-needed salbutamol use in patients with moderate asthma. European Respiratory Journal 2001;18 (Suppl 33):426s.

Cheung 2006 \{published data only\} Cheung D, van Klink HCJ, Aalbers R. Improved lung function and symptom control with formoterol on demand in asthma. European Respiratory Journal 2006;27(3): 504-10.

Cheung D, van Klink RCJ, Aalbers R. Improved asthma control with formoterol "as needed" compared to salbutamol in patients with asthma. American Thoracic Society 99th International Conference. 2003:B036 Poster H73.

Van Klink HCJ, Cheung D, Aalbers R. Formoterol as relief medication is increasingly more effective than salbutamol in patients with increasing need for reliever therapy. European Respiratory Journal 2003;22(Suppl 45):P1572.

Kesten 1991 \{published data only\}

Kesten S, Chapman KR, Broder I, Cartier A, Hyland RH, Knight A, et al.A three-month comparison of twice daily inhaled formoterol versus four times daily inhaled albuterol in the management of stable asthma. American Review of Respiratory Disease 1991:622-5.

O'Connor 2000 \{published data only\}

O'Connor B, McSorley L, Turbitt M. Does treatment with eformoterol turbohaler ${ }^{\circledR}$ prn allow a reduction in the number of inhalers used to treat moderate to severe asthma? [Abstract]. American Journal of Respiratory and Critical Care Medicine 2000;161(Suppl 3):A191.

O'Connor B, McSorley LC, Turbitt ML. Use of formeterol (Oxis $\left.{ }^{\circledR}\right)$ Turbuhaler ${ }^{\circledR}$ as needed in moderate to severe asthma reduces the number of inhalers used whilst maintaining effectiveness. American Journal of Respiratory and Critical Care Medicine. 2001; Vol. 107(2):S108.

Richter 2007 \{published data only\}

Richter K, Hartmann U, Metzenauer P, Magnussen H. Randomised trial comparing as-needed versus regular treatment with formoterol in patients with persistent asthma. Respiratory Medicine 2007;101(3):467-75.

\section{Additional references}




\section{Adams 2008}

Adams NP, Bestall JC, Lasserson TJ, Jones PW, Cates CJ Fluticasone versus placebo for chronic asthma in adults and children. Cochrane Database of Systematic Reviews 2008, Issue 4. [DOI: 10.1002/14651858.CD003135.pub4]

\section{AstraZeneca Briefing Document}

AstraZeneca Briefing Materials: Review of the Benefits and Risks of Formoterol-containing Products. www.fda.gov/ ohrms/dockets/ac/08/briefing/2008-4398b1-03AstraZeneca.pdf 3 November 2008.

\section{Barnes 2007}

Barnes PJ. Using a combination inhaler (budesonide plus formoterol) as rescue therapy improves asthma control. BMJ 2007; Vol. 335, issue 7618:513-17.

\section{Bisgaard 2003}

Bisgaard $\mathrm{H}$. Effect of long-acting beta 2 agonists on exacerbation rates of asthma in children. Pediatric Pulmonology 2003;36(5):391-8.

BNF

British National Formulary 59. http://bnf.org/bnf/bnf/ current/index.htm (accessed 14 May 2010).

\section{BTS/SIGN 2008}

British Thoracic Society. British Guidelines on Asthma Management. Thorax 2008; Vol. 63, issue Suppl 1.

\section{Cates 2008}

Cates CJ, Cates MJ. Regular treatment with salmeterol for chronic asthma: serious adverse events (Cochrane Review). Cochrane Database of Systematic Reviews 2008, Issue 3. [DOI: 10.1002/14651858.CD006363.pub2]

\section{Cates 2008a}

Cates CJ, Cates MJ, Lasserson TJ. Regular treatment with formoterol for chronic asthma: serious adverse events. Cochrane Database of Systematic Reviews 2008, Issue 4. [DOI: 10.1002/14651858.CD006923.pub2]

\section{Cates 2009}

Cates CJ, Lasserson TJ. Combination formoterol and inhaled steroid versus beta2-agonist as relief medication for chronic asthma in adults and children. Cochrane Database of Systematic Reviews 2009, Issue 1. [DOI: 10.1002/ 14651858.CD007085.pub2]

\section{Cates 2009a}

Cates CJ, Lasserson TJ. Combination formoterol and budesonide as maintenance and reliever therapy versus inhaled steroid maintenance for chronic asthma in adults and children. Cochrane Database of Systematic Reviews 2009, Issue 2. [DOI: 10.1002/14651858.CD007313.pub2]

\section{Cates 2009b}

Cates CJ, Lasserson TJ, Jaeschke R. Regular treatment with formoterol and inhaled steroids for chronic asthma: serious adverse events. Cochrane Database of Systematic Reviews 2009, Issue 2. [DOI: 10.1002/14651858. CD006924.pub2]

\section{Delea 2008}

Delea TE, Hagiwara M, Stanford RH, Stempel DA. Effects of fluticasone propionate/salmeterol combination on asthma-related health care resource utilization and costs and adherence in children and adults with asthma. Clinical Therapeutics 2008; Vol. 30, issue 3:560-71.

\section{FDA website}

Information for Healthcare Professionals Formoterol fumarate (marketed as Foradil). http://www.fda.gov/Drugs/DrugSafety/ PostmarketDrugSafetyInformationforPatientsandProviders/ ucm162677.htm (accessed 11 May 2010).

\section{Higgins 2003}

Higgins JPT, Thompson SG, Deeks JJ, Altman DG. Measuring inconsistency in meta-analyses. BMJ 2003;327: $557-60$.

\section{Higgins 2008}

Higgins JPT, Green S (editors). Cochrane Handbook for Systematic Reviews of Interventions Version 5.0.0 [updated February 2008] Available from: www.cochrane-handbook.org. The Cochrane Collaboration, 2008.

Lipworth 2007

Lipworth BJ, Jackson C. A SMART choice for primary care asthma therapy?. http://www.bmj.com/cgi/eletters/335/ 7618/513\#178078 13 October 2007.

\section{Lötvall 2008}

Lötvall Jan, Ankerst Jaro. Long duration of airway but not systemic effects of inhaled formoterol in asthmatic patients. Respiratory Medicine 2008;102(3):449-56.

\section{Miranda 2003}

Miranda C, Busacker A, Balzar S, Trudeau J, Wenzel SE. Distinguishing severe asthma phenotypes: role of age at onset and eosinophilic inflammation. Journal of Allergy and Clinical Immunology 2003;113(1):101-8.

\section{Palmqvist 2001}

Palmqvist M, Arvidsson P, Beckman O, Peterson S, Lotvall J. Onset of bronchodilation of budesonide/formoterol vs. salmeterol/fluticasone in single inhalers. Pulmonary Pharmacology \& Therapeutics 2001;14(1):29-34.

\section{Pavord 2009}

Pavord ID, Jeffery PK, Qiu Y, Zhu J, Parker D, Carlsheimer A, et al.Airway inflammation in patients with asthma with high-fixed or low-fixed plus as-needed budesonide/ formoterol. Journal of Allergy and Clinical Immunology. 2009;123(5):1083-9.

\section{RevMan 2008}

The Nordic Cochrane Centre, The Cochrane Collaboration. Review Manager (RevMan). 5.0. Copenhagen: The Nordic Cochrane Centre, The Cochrane Collaboration, 2008.

\section{Rodrigo 2010}

Rodrigo Gustavo J. Increased risk of asthma death with salmeterol monotherapy compared with placebo, but not with salmeterol plus inhaled corticosteroids compared with inhaled corticosteroids alone. Evidence Based Medicine 2010;15(2):37-8.

Sovani 2008

Sovani MP, Whale CI, Oborne J, Cooper S, Mortimer K, Ekström T, et al.Poor adherence with inhaled corticosteroids 
for asthma: can using a single inhaler containing budesonide and formoterol help?. British Journal of General Practice 2008;58(546):37-43.

Walters 2007

Walters EH, Gibson PG, Lasserson TJ, Walters JAE.

Long-acting beta2-agonists for chronic asthma in adults and children where background therapy contains varied or no inhaled corticosteroid. Cochrane Database of Systematic Reviews 2007, Issue 1. [DOI: 10.1002/ 14651858.CD001385.pub2]

Wijesinghe 2009

Wijesinghe M, Weatherall M, Perrin K, Harwood M,

Beasley R. Risk of mortality associated with formoterol: a systematic review and meta-analysis. Postgraduate Medical Journal 2009;34(4):803-11.

* Indicates the major publication for the study 
CHARACTERISTICS OF STUDIES

Characteristics of included studies [ordered by study ID]

Ind 2002

Methods

Study design: randomised, double-blind, parallel-group

Study duration: 12 weeks

Number of study centres and location: 42 centres in 5 countries (the UK, Spain, Israel,

Finland and Hungary)

Participants

$\mathrm{N}$ randomised (males): formoterol maintenance plus formoterol as-needed 176 (67), formoterol maintenance plus terbutaline as-needed 181 (76)

Withdrawals: formoterol maintenance plus formoterol as-needed 7 and formoterol maintenance plus terbutaline as-needed 1

Age mean (range): 47

Asthma severity: patients had to have been stable on an adequate constant dose of ICS for $>4$ weeks. Patients were also included if $\leq 10 \mathrm{mg}$ per day of oral prednisolone or equivalent

Diagnostic criteria: ATS

Baseline ICS use: formoterol maintenance plus formoterol as-needed $1034 \mu \mathrm{g}$ (200 to 2900), formoterol maintenance plus terbutaline as-needed1030 $\mu \mathrm{g}$ (200 to 3200)

Baseline lung function, FEV1 (\% predicted): formoterol maintenance plus formoterol as-needed $2.23 \mathrm{~L}$ (76\%), formoterol maintenance plus terbutaline as-needed $2.24 \mathrm{~L}$ (76\%)

Inclusion criteria: patients $>18$ years with FEV1 $>50 \%$ predicted normal. Patients requiring 2 to 5 inhalations per day of as-needed terbutaline during run-in. Patients must have completed the run-in according to protocol

Exclusion criteria: patients with significant cardiovascular disease, pregnant or breastfeeding women or patients with hypersensitivity to lactose or beta 2 -agonists. Beta 2 -agonist, anticholinergics, leukotriene receptor agonists, cromones or immunotherapy were not permitted. Patients who used $>8$ inhalations during a single day during run-in

Interventions

Run-in: 2 weeks on formoterol $9 \mu \mathrm{g}$ twice a day and terbutaline Turbuhaler $0.5 \mathrm{mg}$ asneeded

Intervention: formoterol $9 \mu \mathrm{g}$ twice a day plus formoterol Turbuhaler $4.5 \mu \mathrm{g}$ as-needed Control: formoterol $9 \mu \mathrm{g}$ twice a day plus terbutaline Turbuhaler $0.5 \mathrm{mg}$ as-needed Instructions provided for as-needed therapy: "use as-needed medication for either relief of asthma symptoms or prevention of bronchoconstriction (e.g. before exercise) and to appraise the effect of each inhalation before proceeding with as second"

Average puffs per day used, mean (range): formoterol as-needed 2.16 (0.0 to 6.3), terbutaline as-needed 2.34 (0.1 to 7.5$)$

Co-medication: all on inhaled or oral corticosteroids at a constant dose

Outcomes

Primary outcomes: serum potassium levels, ECG, vital signs, lung function, adverse events

Secondary outcomes: number of inhalations of as-needed medication, severe asthma exacerbations, lung function, asthma symptoms

Time points: attended clinic on 5 occasions with telephone calls to check on usage of reliever medication and adverse events between visits 
Definition of severe asthma exacerbation: either a requirement for oral glucocorticosteroids, either as judged by the investigator or following a drop in PEF on 2 consecutive days to $<70 \%$ of mean baseline value. Treated with $30 \mathrm{mg} /$ day oral prednisolone for 10 days reducing dose by $5 \mathrm{mg} /$ day over the next 5 days. Patients withdrawn after a second exacerbation

Notes

\section{Risk of bias}

\begin{tabular}{|c|c|c|}
\hline Item & Authors' judgement & Description \\
\hline Adequate sequence generation? & Yes & “randomised" \\
\hline Allocation concealment? & Yes & $\begin{array}{l}\text { From correspondence: "Patients received } \\
\text { an enrolment code in consecutive order per } \\
\text { centre at visit } 1 \text {. Eligible patients... were al- } \\
\text { located a randomised patient No. in con- } \\
\text { secutive order, per centre, at visit } 2 . \text { " }\end{array}$ \\
\hline $\begin{array}{l}\text { Blinding? } \\
\text { Objective outcomes; hospitalisation, } \\
\text { deaths, SAEs }\end{array}$ & Yes & $\begin{array}{l}\text { "Double blind". Both study drugs admin- } \\
\text { istered by identical inhalers }\end{array}$ \\
\hline $\begin{array}{l}\text { Blinding? } \\
\text { subjective outcomes; exacerbations requir- } \\
\text { ing OCS, asthma-related SAEs, withdrawal }\end{array}$ & Yes & "Double blind" \\
\hline Incomplete outcome data addressed? & Unclear & $\begin{array}{l}\text { The numbers of withdrawals in each treat- } \\
\text { ment arm were not described adequately in } \\
\text { the text }\end{array}$ \\
\hline Free of selective reporting? & Yes & $\begin{array}{l}\text { Outcomes reported, although numerical } \\
\text { data not given for PEF and FEV1 apart } \\
\text { from a graph that no data could be obtained } \\
\text { from }\end{array}$ \\
\hline Free of other bias? & Yes & None noted \\
\hline
\end{tabular}

Jain 2004

\begin{tabular}{ll} 
Methods & Study duration: 6 months \\
\hline Participants & N completed (males): formoterol 29, salbutamol 31 \\
\hline Interventions & $\begin{array}{l}\text { Intervention: formoterol } 4.5 \mu \mathrm{g} \text { as-needed } \\
\text { Control: salbutamol } 100 \mu \mathrm{g} \text { as-needed } \\
\text { Instructions provided for as-needed therapy: formoterol 1 puff as-needed, salbutamol } 2\end{array}$ \\
\hline
\end{tabular}


Jain 2004 (Continued)

\begin{tabular}{l|l} 
& $\begin{array}{l}\text { puffs as-needed } \\
\text { Average puffs per day used, mean (range): }\end{array}$ \\
\hline Outcomes & Time points: 30,90 and 180 days \\
\hline Notes & $\begin{array}{l}\text { Completed diary card for } 2 \text { weeks prior to } 3 \text { data collection visits } \\
\text { This study was reported as an abstract and we were not provided with further details on } \\
\text { request and so the details reported here are limited }\end{array}$ \\
\hline
\end{tabular}

\section{Risk of bias}

\begin{tabular}{|c|c|c|}
\hline Item & Authors' judgement & Description \\
\hline Adequate sequence generation? & Unclear & $\begin{array}{l}\text { "Randomised" } \\
\text { Comment: not stated, possibly done }\end{array}$ \\
\hline Allocation concealment? & Unclear & Comment: not stated, possibly done \\
\hline $\begin{array}{l}\text { Blinding? } \\
\text { Objective outcomes; hospitalisation, } \\
\text { deaths, SAEs }\end{array}$ & Unclear & Comment: not stated, possibly done \\
\hline $\begin{array}{l}\text { Blinding? } \\
\text { subjective outcomes; exacerbations requir- } \\
\text { ing OCS, asthma-related SAEs, withdrawal }\end{array}$ & Unclear & Comment: not stated, possibly done \\
\hline Incomplete outcome data addressed? & Unclear & Withdrawals not stated \\
\hline Free of selective reporting? & Unclear & $\begin{array}{l}\text { "data were analysed for safety and efficacy variables" } \\
\text { Comment: since we do not know what outcomes the trial- } \\
\text { ists were planning to measure, we cannot assess this } \\
\text { It was not clear whether hospitalisations or courses of oral } \\
\text { corticosteroids were per event or per individual }\end{array}$ \\
\hline Free of other bias? & No & $\begin{array}{l}\text { Publication bias. There was only a single abstract published } \\
\text { on this trial }\end{array}$ \\
\hline
\end{tabular}




Study design: randomised, double-blind, parallel-group, active-controlled, phase IIIB
Study duration: 2 -week run-in plus 12-month study
Number of study centres and location: 289 centres from 20 countries (Belgium, Bul-
garia, China, Czech Republic, Germany, Greece, Hungary, Indonesia, Italy, Malaysia,
the Netherlands, Norway, the Philippines, Poland, Romania, Russia, Slovakia, South
Africa, South Korea and Vietnam)
Date of study: 10 April 2003 to 21 December 2004

Participants

Interventions
$\mathrm{N}$ randomised (males): budesonide/formoterol for maintenance plus formoterol asneeded 1140 (458), budesonide/formoterol for maintenance plus terbutaline as-needed 1141 (450)

Withdrawals: budesonide/formoterol single inhaler plus formoterol as-needed 132, budesonide/formoterol single inhaler plus terbutaline as-needed 122

Age, mean (range): 42 (12 to 81 )

Asthma severity: moderate to severe asthma and documented symptoms despite use of ICS

Diagnostic criteria: ATS

Baseline ICS use: all on ICS. Budesonide/formoterol single inhaler plus formoterol 758 $\mu \mathrm{g}$ (320 to 1600), budesonide/formoterol single inhaler plus terbutaline $751 \mu \mathrm{g}$ (250 to 1600$)$

Baseline lung function, FEV1 [range] (\% predicted): budesonide/formoterol single inhaler plus formoterol $2.20 \mathrm{~L}$ [0.74 to 4.58$]$ (72\%), budesonide/formoterol single inhaler plus terbutaline $2.16 \mathrm{~L}$ [0.68 to 4.58$]$ ( $72 \%)$

Inclusion criteria: outpatients $>12$ years, clinical diagnosis of asthma for $\geq 6$ months with $>1$ severe asthma exacerbation in the 12 months before entry. All patients used ICS for $\geq 3$ months and at a constant dose for 4 weeks prior to study. FEV $1 \geq 50 \%$ predicted with $\geq 12 \%$ reversibility after inhalation of $1 \mathrm{mg}$ terbutaline. Used reliever medication on 5 or more of the last 7 days of run-in

Exclusion criteria: any respiratory infection affecting the patients asthma or use of OCS within 1 month of study entry

Run-in: 2 weeks. Symbicort (budesonide/formoterol) Turbuhaler 160/4.5 $\mu \mathrm{g} 1$ inhalation twice a day as maintenance and terbutaline turbuhaler $0.5 \mathrm{mg}$ per inhalation asneeded

Intervention: budesonide/formoterol Turbuhaler 160/4.5 $\mu \mathrm{g} 1$ inhalation twice a day as maintenance and formoterol turbuhaler $4.5 \mu \mathrm{g}$ as-needed

Control: budesonide/formoterol Turbuhaler 160/4.5 $\mu \mathrm{g} 1$ inhalation twice a day as maintenance and terbutaline turbuhaler $0.4 \mathrm{mg}$ per inhalation as-needed

Instructions provided for as-needed therapy: "patients were instructed to use their reliever medication for asthma symptoms, but not prophylaxis. During treatment, patients were not allowed to use more than ten inhalations of reliever medication a day."

Average puffs per day used, mean (range): formoterol as-needed 1.90 (0.00 to 9.14), terbutaline as needed 1.91 ( 0.30 to 9.73$)$

Co-medication: participants stopped taking ICS at baseline and started taking budesonide/formoterol

Definition of severe asthma exacerbation: deterioration in asthma resulting in emergency treatment or hospitalisation or the need for oral steroids for 3 days or more (as judged by the investigator) 
Rabe 2006 (Continued)

\begin{tabular}{ll}
\hline Outcomes & Primary outcome: time to first severe asthma exacerbation (hospitalisation of ER/ED \\
visit, course of OCS lasting at least 3 days as judged by the investigator). Days with OCS \\
recorded \\
Secondary outcomes: number of severe and mild asthma exacerbations, number of hos- \\
pitalisations/ED visits, intake of maintenance medication, FEV1, FVC, morning and \\
evening PEF, asthma symptom score, inhalations of as-needed medication, night awak- \\
enings due to asthma symptoms, as-needed free days, time to first mild exacerbation, \\
patient recorded outcomes and asthma control questionnaire, health economics resource \\
utilisation and sick days. Percentage of asthma control days (24 hours with no symptoms, \\
no intake of as-needed medication and no night-time awakening due to asthma). Safety \\
variables were nature, incidence and severity of adverse events \\
Time points: beginning and end of run-in and after $1,4,8$ and 12 months of study \\
treatment
\end{tabular}

There were 71 serious adverse events in 55 patients on formoterol compared to 83 events in 65 patients on terbutaline

\section{Risk of bias}

\begin{tabular}{|c|c|c|}
\hline Item & Authors' judgement & Description \\
\hline Adequate sequence generation? & Yes & $\begin{array}{l}\text { "Randomisation schedule computer gener- } \\
\text { ated at AstraZeneca Research and Devel- } \\
\text { opment, Charnwood UK, by a person in- } \\
\text { dependent of the study team." }\end{array}$ \\
\hline Allocation concealment? & Yes & $\begin{array}{l}\text { "Within each study centre, eligible patients } \\
\text { were sequentially assigned a randomisation } \\
\text { code by the investigator from the computer } \\
\text { generated list." }\end{array}$ \\
\hline $\begin{array}{l}\text { Blinding? } \\
\text { Objective outcomes; hospitalisation, } \\
\text { deaths, SAEs }\end{array}$ & Yes & $\begin{array}{l}\text { "as all needed study medication was given } \\
\text { via identical turbuhalers, all matched in ap- } \\
\text { pearance." }\end{array}$ \\
\hline $\begin{array}{l}\text { Blinding? } \\
\text { subjective outcomes; exacerbations requir- } \\
\text { ing OCS, asthma-related SAEs, withdrawal }\end{array}$ & Yes & As above \\
\hline Incomplete outcome data addressed? & Yes & $\begin{array}{l}\text { Full analysis set included all randomised } \\
\text { patients who provided data after randomi- } \\
\text { sation. Reasons given for withdrawal simi- } \\
\text { lar across arms }\end{array}$ \\
\hline Free of selective reporting? & Yes & $\begin{array}{l}\text { All the outcomes that we were interested in } \\
\text { were reported }\end{array}$ \\
\hline Free of other bias? & Yes & None noted \\
\hline
\end{tabular}




\begin{tabular}{|c|c|}
\hline Methods & $\begin{array}{l}\text { Study design: Multi-national, multi-centre, randomised, open, parallel-group } \\
\text { Study duration: } 6 \text { months } \\
\text { Number of study centres and location: } 1139 \text { in } 24 \text { countries } \\
\text { Date of study: } 17 \text { April } 2000 \text { to } 24 \text { June } 2001\end{array}$ \\
\hline Participants & $\begin{array}{l}\text { N randomised (males): formoterol } 8924 \text { (3924), salbutamol } 8938 \text { (3798) } \\
\text { Withdrawals: formoterol } 664 \text {, salbutamol } 525 \\
\text { Age, mean (range): } 39 \text { ( } 4 \text { to } 91 \text { ) } \\
\text { Asthma severity: any allowed, defined by use of maintenance treatment at entry as } \\
\text { intermittent (no maintenance treatment), mild (ICS }<500 \mu \mathrm{g} \text { per day or regular LABA, } \\
\text { cromone, theophylline or leukotriene modifier), moderate (ICS alone } \geq 500 \mu \mathrm{g} \text { per day } \\
\text { or ICS } 500 \text { to } 800 \mu \mathrm{g} \text { per day in combination with LABA, theophylline or leukotriene } \\
\text { modifier) and severe (ICS }>800 \mu \mathrm{g} \text { per day in combination with LABA, theophylline } \\
\text { or leukotriene modifier, or oral corticosteroids) } \\
\text { Intermittent: } 16 \% \text {, mild: } 35 \% \text {, moderate: } 35 \% \text {, severe: } 15 \% \\
\text { Diagnostic criteria: judged by asthma medication levels, GINA } \\
\text { Baseline ICS use: } 76 \% \text { using ICS. Mean usage at baseline } 753 \mu \mathrm{g} \text { (formoterol group), } \\
763 \mu \mathrm{g} \text { (salbutamol group) } \\
\text { Baseline LABA use: } 31 \% \\
\text { Baseline lung function, FEV1 (\% predicted): not reported } \\
\text { Inclusion criteria: } \geq 6 \text { years, previous use of or candidates for beta } 2 \text {-agonist reliever } \\
\text { therapy } \\
\text { Exclusion criteria: women who were pregnant, breast-feeding or not using appropriate } \\
\text { contraception. Patients with concomitant cardiovascular diseases were included at physi- } \\
\text { cians' discretion }\end{array}$ \\
\hline
\end{tabular}

Interventions

\section{Run-in: none}

Intervention: formoterol $4.5 \mu \mathrm{g}$, Turbuhaler DPI

Control: salbutamol $200 \mu \mathrm{g}$ delivered by Turbuhaler dry powder inhaler in 6 countries and by pressurised metered dose inhaler in 18 countries

Instructions provided for as-needed therapy: patients instructed to contact investigator if they used more that 12 puffs reliever medication in adults and 8 in children in 1 day, with lower limits for those on LABA

Average puffs per day used, mean (range): not reported

Co-medication: any ordinary asthma maintenance medication, except other reliever medication was allowed and investigators could change the maintenance medication according to clinical judgement

Definition of asthma exacerbation: any of: 1) increase in maintenance asthma medication, 2) course of ICS $\geq 5$ days, 3) emergency treatment with nebulised beta 2 -agonist or corticosteroid injection, 4) hospitalisation

Definition of severe asthma exacerbation: any of: 1) course of ICS $\geq 5$ days, 2) emergency treatment with nebulised beta 2 -agonist or corticosteroid injection, 3) hospitalisation
Outcomes
Efficacy outcomes collected: primary efficacy variable was time to first asthma exacerbation. Secondary variables: change in concomitant maintenance asthma medication, number of inhalations of study drug, number of days with asthma symptoms, health care resource utilisation, days restricted activity Safety outcomes collected: primary safety variables were asthma-related and non-asthmarelated serious adverse events and adverse events resulting in discontinuations Time points: 1,3 and 6 months 
RELIEF 2003 (Continued)

\begin{tabular}{|c|c|c|}
\hline Notes & \multicolumn{2}{|c|}{$\begin{array}{l}\text { There were } 305 \text { serious adverse events in } 278 \text { patients on formoterol compared to } 327 \\
\text { events in } 299 \text { patients on salbutamol }\end{array}$} \\
\hline \multicolumn{3}{|l|}{ Risk of bias } \\
\hline Item & Authors' judgement & Description \\
\hline Adequate sequence generation? & Yes & "computer generated code" \\
\hline Allocation concealment? & Yes & $\begin{array}{l}\text { "At entry, patients were randomised in } \\
\text { chronological order at each site, according } \\
\text { to a computer generated code and treat- } \\
\text { ment communicated via code envelope" }\end{array}$ \\
\hline $\begin{array}{l}\text { Blinding? } \\
\text { Objective outcomes; hospitalisation, } \\
\text { deaths, SAEs }\end{array}$ & Yes & $\begin{array}{l}\text { "Open label" } \\
\text { Comment: the study was open-label, but } \\
\text { knowing the assignment of medication is } \\
\text { unlikely to make a difference when judg- } \\
\text { ing when a participant experienced death, } \\
\text { hospitalisation or all-cause serious adverse } \\
\text { event }\end{array}$ \\
\hline $\begin{array}{l}\text { Blinding? } \\
\text { subjective outcomes; exacerbations requir- } \\
\text { ing OCS, asthma-related SAEs, withdrawal }\end{array}$ & Unclear & $\begin{array}{l}\text { Comment: because the study was open-la- } \\
\text { bel, this may introduce bias when investi- } \\
\text { gators were subjectively judging whether a } \\
\text { serious adverse event was related to asthma } \\
\text { or required a course or oral corticosteroids. } \\
\text { Knowledge of the treatment drug might } \\
\text { influence a patient's decision to withdraw } \\
\text { from the study }\end{array}$ \\
\hline Incomplete outcome data addressed? & Yes & $\begin{array}{l}\text { All analyses were performed on intention- } \\
\text { to-treat population and there were few } \\
\text { withdrawals }\end{array}$ \\
\hline Free of selective reporting? & Yes & $\begin{array}{l}\text { The number of outcomes measured was } \\
\text { kept to a minimum as RELIEF was a large } \\
\text { study and they were all reported }\end{array}$ \\
\hline Free of other bias? & Yes & None noted \\
\hline
\end{tabular}




N randomised (males): formoterol 228 (113), terbutaline 227 (119)
Withdrawals: formoterol 11, terbutaline 20
Age, mean (range): 25 ( 6 to 75$)$
Asthma severity: mild
Diagnostic criteria: GINA
Baseline ICS use, mean (range): on a regular stable dose of ICS formoterol group 376
$\mu \mathrm{g}(200$ to 900$)$ daily, terbutaline $388 \mu \mathrm{g}(200$ to 800$)$ daily
Baseline lung function, FEV1 mean [range] (\% predicted): formoterol $2.91[1.12$ to 5.
38] $(101 \%)$, terbutaline $2.92[0.96$ to 5.77$]$ (100\%)
Inclusion criteria: Visit $1: \geq 6$ years old with a diagnosis of asthma (ATS). Baseline
FEV1 $\geq 80 \%$ predicted normal. Stable inhaled steroid dose of $\geq 200$ but $\leq 500 \mu \mathrm{g} /$
day, nedocromyl or cromoglycate treatment for at least 4 weeks prior to enrolment. Visit
$2:$ use of as-needed medication drug between $\geq 3$ inhalation occasions/week and $\leq 4$
inhalations/day during the run-in period
Exclusion criteria: Visit 1. Use of LABA 3 months prior. Use of a beta-blocker including
eye drops. Respiratory infection affecting the asthma within 4 weeks prior to enrolment,
as judged by the investigator. Smoking history $\geq 10$ pack-years. Women who were
pregnant, breastfeeding or not using an acceptable method of contraception. Visit 2.
$<16$ morning PEF values in the diary, any significant respiratory infection, change in
prescribed asthma medication during run-in

Definition of severe asthma exacerbation: the need for oral corticosteroid course or hospitalisation due to asthma month period. Secondary variables: FEV1 pre- and post-bronchodilator, evening PEF, day- and night-time use of study medication, day- and night-time asthma symptoms, time to first asthma exacerbation, provocative cumulative dose of metacholine giving a $20 \%$ fall in FEV1 $\left(\mathrm{PD}_{20}\right)$.

Safety outcomes collected: adverse events, clinical chemistry, haematology and urinalysis, ECG, systolic and diastolic blood pressure

Time points: start and end of run-in, at 1, 2, 4, 6, 8, 10 and 12 months plus telephone call between visits as needed in patients with intermittent or mild persistent asthma. Respiratory medicine 2005;99(4):461-70

\section{Risk of bias}


SD-037-0714 (Continued)

\begin{tabular}{|c|c|c|}
\hline Item & Authors' judgement & Description \\
\hline Adequate sequence generation? & Yes & $\begin{array}{l}\text { "randomised" } \\
\text { Subjects stratified according to age ( } 6 \text { to } \\
11,12 \text { to } 17, \geq 18 \text { years) and a different } \\
\text { randomisation list was used for each group }\end{array}$ \\
\hline Allocation concealment? & Yes & $\begin{array}{l}\text { From correspondence: patients "who ful- } \\
\text { filled all the inclusion and none of the ex- } \\
\text { clusion criteria were given a randomisation } \\
\text { number at visit } 2 . " \text { The "randomisation } \\
\text { number was allocated in sequential order. } \\
\text { If a subject discontinued participation in } \\
\text { the study, the number was not re-used." }\end{array}$ \\
\hline $\begin{array}{l}\text { Blinding? } \\
\text { Objective outcomes; hospitalisation, } \\
\text { deaths, SAEs }\end{array}$ & Yes & $\begin{array}{l}\text { "double blind" } \\
\text { From correspondence: "The study was } \\
\text { double blind and all inhalers were identical } \\
\text { in appearance. The treatment was not to be } \\
\text { prematurely broken unless in an emergency } \\
\text { situation when the appropriate manage- } \\
\text { ment of the subject necessitated knowledge } \\
\text { of the treatment allocation. Prior to break- } \\
\text { ing treatment codes, all decisions taken on } \\
\text { data validation for each individual subject } \\
\text { had to be documented." }\end{array}$ \\
\hline $\begin{array}{l}\text { Blinding? } \\
\text { subjective outcomes; exacerbations requir- } \\
\text { ing OCS, asthma-related SAEs, withdrawal }\end{array}$ & Unclear & $\begin{array}{l}\text { From correspondence: the drug safety de- } \\
\text { partment at AstraZeneca could break the } \\
\text { treatment codes if serious adverse events } \\
\text { were suspected to be causally related to the } \\
\text { study medications, if expedited reporting } \\
\text { to authorities was required or in exceptional } \\
\text { circumstances for other safety reasons }\end{array}$ \\
\hline Incomplete outcome data addressed? & Yes & $\begin{array}{l}\text { The results were analysed on an intention- } \\
\text { to- treat basis. The withdrawals were bal- } \\
\text { anced between arms and in line with other } \\
\text { studies and reasons were provided }\end{array}$ \\
\hline Free of selective reporting? & Yes & None noted \\
\hline Free of other bias? & Yes & None noted \\
\hline
\end{tabular}




\begin{tabular}{|c|c|}
\hline Participants & $\begin{array}{l}\mathrm{N} \text { randomised (males): formoterol } 333 \text { (194), terbutaline } 342 \text { (208) } \\
\text { Withdrawals: formoterol } 23 \text {, terbutaline } 28 \\
\text { Age, mean (range): formoterol } 23 \text { ( } 6 \text { to } 73 \text { ), terbutaline } 24 \text { ( } 6 \text { to } 87 \text { ) } \\
\text { Asthma severity: intermittent } \\
\text { Diagnostic criteria: ATS } \\
\text { Baseline ICS use: not on ICS or LABA } \\
\text { Baseline lung function, FEV1 mean [range] (\% predicted): formoterol } 3.11 \text { L [0.98 to } \\
5.56 \text { ] ( } 98 \% \text { ), terbutaline } 3.15 \mathrm{~L} \text { [ } 1.14 \text { to } 6.80 \text { ] ( } 97 \%) \\
\text { Inclusion criteria: Visit } 1 . \geq 6 \text { years old with a diagnosis of asthma according to the ATS. } \\
\text { Baseline FEV1 } \geq 80 \% \text { predicted normal. Informed consent. Visit } 2 \text {. Use of SABA on } \\
\text { between } 2 \text { and } 6 \text { occasions during the last } 2 \text { weeks of the run-in } \\
\text { Exclusion criteria: Visit } 1 \text {. Use of ICS, other anti-inflammatory treatment or LABA } 3 \\
\text { months prior. Use of a beta-blocker including eye drops. Respiratory infection affecting } \\
\text { the asthma within } 4 \text { weeks prior to enrolment, as judged by the investigator. Smoking } \\
\text { history } \geq 10 \text { pack-years. Use of unallowed medication. Women who were pregnant, } \\
\text { breastfeeding or not using an acceptable method of contraception. Visit } 2 .<16 \text { morning } \\
\text { PEF values in the diary, any significant respiratory infection, change in prescribed asthma } \\
\text { medication during run-in }\end{array}$ \\
\hline Interventions & $\begin{array}{l}\text { Run-in: } 3 \text { weeks on Bricanyl terbutaline Turbuhaler } 0.5 \mathrm{mg} \text { as-needed. Single-blind } \\
\text { Intervention: Oxis formoterol Turbuhaler } 4.5 \mu \mathrm{g} \text { as-needed } \\
\text { Control: Bricanyl terbutaline Turbuhaler } 0.5 \mathrm{mg} \\
\text { Co-medication: not ICS or LABA } \\
\text { Definition of severe asthma exacerbation: the need for oral corticosteroid course or } \\
\text { hospitalisation due to asthma }\end{array}$ \\
\hline
\end{tabular}

Outcomes

Notes
Efficacy outcomes collected: primary variable: average morning PEF over the entire 12month period. Secondary variables: FEV1 pre- and post-bronchodilator. Evening PEF, average daily number of inhalations of as-needed, day-and night-time asthma symptoms, time to first asthma exacerbation, provocative cumulative dose of metacholine giving a $20 \%$ fall in FEV1 $\left(\mathrm{PD}_{20}\right)$.

Safety outcomes collected: adverse events, clinical chemistry, haematology and urinalysis, ECG, systolic and diastolic blood pressure

Time points: 1 screening visit, 1 at the end of run-in and after 1, 2, 4, 6, 8, 10 and 12 months treatment. Subjects contacted by phone between visits to check adverse events and compliance

Full text: Chuchalin A, Kasl M, Bengtsson T, Nihlen U, Rosenborg J. Formoterol used as needed in patients with intermittent or mild persistent asthma. Respiratory medicine 2005;99(4):461-70

Risk of bias 
SD-037-0716 (Continued)

\begin{tabular}{|c|c|c|}
\hline Item & Authors' judgement & Description \\
\hline Adequate sequence generation? & Yes & $\begin{array}{l}\text { "randomised" } \\
\text { Subjects stratified according to age ( } 6 \text { to } \\
11,12 \text { to } 17, \geq 18 \text { years) and a different } \\
\text { randomisation list was used fro each group }\end{array}$ \\
\hline Allocation concealment? & Yes & $\begin{array}{l}\text { From correspondence: "At visit one all sub- } \\
\text { jects received an enrolment code. The sub- } \\
\text { jects who fulfilled all inclusion and none } \\
\text { of the exclusion criteria were given a sub- } \\
\text { ject number at visit two. Both the enrol- } \\
\text { ment and subject numbers were allocated } \\
\text { in consecutive order. If a subject discontin- } \\
\text { ued participation in the study, this number } \\
\text { was not to be re-used." }\end{array}$ \\
\hline $\begin{array}{l}\text { Blinding? } \\
\text { Objective outcomes; hospitalisation, } \\
\text { deaths, SAEs }\end{array}$ & Yes & $\begin{array}{l}\text { From correspondence: "The study was } \\
\text { double blind. All inhalers were identical in } \\
\text { appearance" }\end{array}$ \\
\hline $\begin{array}{l}\text { Blinding? } \\
\text { subjective outcomes; exacerbations requir- } \\
\text { ing OCS, asthma-related SAEs, withdrawal }\end{array}$ & Unclear & $\begin{array}{l}\text { The drug safety department at AstraZeneca } \\
\text { could break the treatment codes if an se- } \\
\text { rious adverse events were suspected to be } \\
\text { causally related to the study medications, if } \\
\text { expedited reporting to authorities was re- } \\
\text { quired or in exceptional circumstances for } \\
\text { other safety reasons }\end{array}$ \\
\hline Incomplete outcome data addressed? & Yes & $\begin{array}{l}\text { The results were analysed on an intention- } \\
\text { to-treat basis }\end{array}$ \\
\hline Free of selective reporting? & Yes & None noted \\
\hline Free of other bias? & Yes & None noted \\
\hline
\end{tabular}

\section{Tattersfield 2001}

\begin{tabular}{ll} 
Methods & $\begin{array}{l}\text { Study design: double-blind, randomised, parallel-group } \\
\text { Study duration: } 12 \text { weeks } \\
\text { Number of study centres and location: } 35 \text { centres in } 4 \text { countries (Greece, the Netherlands, } \\
\text { Norway and Sweden) }\end{array}$ \\
\hline Participants & $\begin{array}{l}\text { N randomised: formoterol 182, terbutaline } 180 \\
\text { Withdrawals: } 21 \text { formoterol, } 32 \text { terbutaline }\end{array}$ \\
Age, mean (range): 47 (18 to 75$)$ \\
Asthma severity: FEV1 $>50 \%$ predicted (mild-moderate according to GOLD definition \\
by FEV1)
\end{tabular}


Tattersfield 2001 (Continued)

\begin{tabular}{|c|c|c|}
\hline & \multicolumn{2}{|c|}{$\begin{array}{l}\text { Baseline ICS use: formoterol } 890 \mu \mathrm{g} \text { ( } 200 \text { to } 2800 \text { ), terbutaline } 860 \text { (100 to } 2400) \\
\text { Baseline lung function, FEV1 mean [range] (\% predicted): formoterol } 2.36 \mathrm{~L} \text { [1.13 to } \\
4.30 \text { ] ( } 74 \% \text { ), terbutaline } 2.27 \mathrm{~L} \text { [1.00 to } 4.65 \text { ] ( } 74 \%) \\
\text { Inclusion criteria: } \geq 18 \text { years, asthma for } 6 \text { months or more and been treated with ICS } \\
\text { for }>4 \text { weeks (mean dose } 870 \mu \mathrm{g} \text { daily). FEV1 }>50 \% \text { predicted, and increase in FEV1 } \\
\text { of } \geq 12 \% \text { after inhalation of } 1.5 \mathrm{mg} \text { terbutaline dry-powder inhaler and used the relief } \\
\text { terbutaline turbuhaler on average } 3 \text { to } 8 \text { times per day on at least } 7 \text { days in the run-in } \\
\text { period } \\
\text { Exclusion criteria: patients who needed more than } 12 \text { inhalations per day of relief med- } \\
\text { ication during the run-in period. Patients with a serum potassium value outside the } \\
\text { reference range }\end{array}$} \\
\hline Interventions & \multicolumn{2}{|c|}{$\begin{array}{l}\text { Run-in: } 2 \text { weeks on terbutaline Turbuhaler } \\
\text { Intervention: formoterol } 4.5 \mu \mathrm{g} \text { (metered dose } 6 \mu \mathrm{g} \text { ) } \\
\text { Control: terbutaline Turbuhaler } 0.5 \mathrm{mg} \\
\text { Instructions provided for as-needed therapy: patients told to take medication only when } \\
\text { needed. Patients taking more than } 12 \text { inhalations per day were withdrawn } \\
\text { Average puffs per day used, mean: formoterol as-needed 3.92, terbutaline as-needed } 5 \text {. } \\
52 \\
\text { Co-medication: Patients were all on ICS. Patients were not allowed to take any oral or } \\
\text { inhaled beta } 2 \text {-agonists during the study period apart from the study medication. Other } \\
\text { asthma medications (xanthines, sodium cromoglycate, nedocromil, antihistamines and } \\
\text { diuretics) were allowed provided that they were kept at a constant dosage throughout } \\
\text { the study } \\
\text { Definition of severe asthma exacerbation: the need for oral corticosteroid course, as } \\
\text { judged by investigator, or decreased PEF of more than } 30 \% \text { from baseline on } 2 \text { consecu- } \\
\text { tive days. All severe exacerbations were treated with a } 7 \text {-day course of oral prednisolone }\end{array}$} \\
\hline Outcomes & \multicolumn{2}{|c|}{$\begin{array}{l}\text { Primary: time to first severe exacerbation } \\
\text { Secondary outcome measures included: morning/evening PEF, FEV1, symptoms, num- } \\
\text { ber of relief medication and safety data, including serum potassium concentration and } \\
\text { changes in electrocardiogram } \\
\text { Time points: start of run-in, start of treatment and after } 4,8 \text { and } 12 \text { weeks of treatment. } \\
\text { Contacted by telephone between the last } 4 \text { visits to check for adverse events and study } \\
\text { drug consumption }\end{array}$} \\
\hline Notes & \multicolumn{2}{|l|}{-} \\
\hline \multicolumn{3}{|l|}{ Risk of bias } \\
\hline Item & Authors' judgement & Description \\
\hline Adequate sequence generation? & Yes & $\begin{array}{l}\text { "Patients were randomly assigned to } \\
\text { treatment groups in computer-generated } \\
\text { blocks. The randomisation sequence was } \\
\text { generated by AstraZeneca research and De- } \\
\text { velopment, Lund." }\end{array}$ \\
\hline
\end{tabular}


Tattersfield 2001 (Continued)

\begin{tabular}{|c|c|c|}
\hline Allocation concealment? & Yes & $\begin{array}{l}\text { "Investigators assigned a number to each } \\
\text { patient in order. The study drugs were sent } \\
\text { to each centre's pharmacy with a number al- } \\
\text { located by randomisation before shipping. } \\
\text { " }\end{array}$ \\
\hline $\begin{array}{l}\text { Blinding? } \\
\text { Objective outcomes; hospitalisation, } \\
\text { deaths, SAEs }\end{array}$ & Yes & $\begin{array}{l}\text { "Investigators were unaware of study drug } \\
\text { assignment throughout the study unless a } \\
\text { SAE occurred." }\end{array}$ \\
\hline $\begin{array}{l}\text { Blinding? } \\
\text { subjective outcomes; exacerbations requir- } \\
\text { ing OCS, asthma-related SAEs, withdrawal }\end{array}$ & Unclear & "double blind" \\
\hline Incomplete outcome data addressed? & Yes & $\begin{array}{l}\text { Analysed data on an intention-to-treat ba- } \\
\text { sis. Reasons for withdrawal provided, more } \\
\text { withdrawals due to adverse events in the } \\
\text { terbutaline group }\end{array}$ \\
\hline Free of selective reporting? & Yes & None noted \\
\hline Free of other bias? & Unclear & None noted \\
\hline
\end{tabular}

Villa 2002

Methods

Study design: randomised, double-blind, parallel-group, reference controlled study, phase IIIb

Study duration: 6 months

Number of study centres and location: 77 centres in 9 countries

Date of study: 27 Jan 2000 to 26 March 2001

\begin{tabular}{|c|c|}
\hline Participants & $\begin{array}{l}\text { N randomised (males): formoterol } 277 \text { (178), terbutaline } 275 \text { (180) } \\
\text { Withdrawals: } 17 \text { formoterol, } 18 \text { terbutaline } \\
\text { Age, mean (range): } 11 \text { ( } 5 \text { to } 19 \text { ). Stratified in to } 2 \text { age groups } 6 \text { to } 11 \text { and } 12 \text { to } 17 \text { years } \\
\text { Asthma severity: mild or moderate persistent. Stable on dose of anti-inflammatory and } \\
\text { more than one dose of as-needed medication } \\
\text { Diagnostic criteria: } \\
\text { Baseline ICS use, mean (range): patients on ICS at baseline, formoterol group } 395 \mu \mathrm{g} \\
\text { ( } 50 \text { to } 1400 \text { ) daily, terbutaline group } 406 \mu \mathrm{g} \text { (100 to } 1000 \text { ) daily } \\
\text { Baseline lung function, FEV1 [range] (\% predicted): formoterol } 1.94 \mathrm{~L} \text { [0.75 to } 4.12 \text { ] } \\
\text { ( } 83 \% \text { ), terbutaline } 1.86 \mathrm{~L} \text { [0.77 to } 3.92 \text { ] ( } 80 \%) \\
\text { Inclusion criteria: patients with bronchial asthma on ICS, disodium cromoglycate or } \\
\text { nedocromil. Visit } 1: \text { reversibility in FEV1 ( } 12 \% \text { from baseline of } 9 \% \text { predicted), on } \\
\text { a stable dose of anti-inflammatory treatment and with a demonstrated need for } \leq 1 \\
\text { inhalation per day of SABA during run-in. Visit } 2: \text { average need of }>1 \text { inhalation of } \\
\text { study medication during the last } 14 \text { days of run-in and compliant with the electronic } \\
\text { diary } \\
\text { Exclusion criteria: women who were pregnant, breastfeeding or not on acceptable con- }\end{array}$ \\
\hline
\end{tabular}


Villa 2002 (Continued)

traceptives. Subjects who used $>8$ inhalations of study medication on any single day, had more than 3 days with a missing value for number of inhalations or those who had a respiratory tract infection

$\begin{array}{ll}\text { Interventions } & \text { Run-in: } 3 \text { weeks } \\ \text { Intervention: formoterol Turbuhaler } 4.5 \mu \mathrm{g} \text { as-needed } \\ \text { Control: terbutaline Turbuhaler } 0.25 \mathrm{mg} \text { as-needed } \\ \text { Co-medication: on ICS, disodium cromoglycate or nedocromil }\end{array}$

Primary variable: time to first asthma exacerbation (mild or serious)
Secondary: morning and evening PEF, number of inhalations of study medication, night-
time awakenings due to asthma, days avoiding activity due to asthma symptoms, re-
strictions in activity (all collected days in electronic diary), FEV1 and paediatric Quality
of Life Questionnaire (PAQLQ(S)). Adverse events, ECG variables, pulse and blood
pressure
Time points: 6 months

There were 16 serious adverse events in 15 patients in patients on formoterol compared to 13 events in 11 patients on terbutaline

\section{Risk of bias}

\begin{tabular}{|c|c|c|}
\hline Item & Authors' judgement & Description \\
\hline Adequate sequence generation? & Yes & $\begin{array}{l}\text { "randomised" } \\
\text { From correspondence: "Randomisation } \\
\text { lists were computer generated at As- } \\
\text { traZeneca. Lund." Stratified according to } \\
\text { age groups }\end{array}$ \\
\hline Allocation concealment? & Yes & $\begin{array}{l}\text { From correspondence: "At visit } 1 \text {, all sub- } \\
\text { jects received an enrolment code. The sub- } \\
\text { jects who met the inclusion criteria and } \\
\text { none of the exclusion criteria were also } \\
\text { given a randomisation number at visit } 2 \text {. } \\
\text { If a subject discontinued, that number was } \\
\text { not re-used." }\end{array}$ \\
\hline $\begin{array}{l}\text { Blinding? } \\
\text { Objective outcomes; hospitalisation, } \\
\text { deaths, SAEs }\end{array}$ & Yes & $\begin{array}{l}\text { "double-blind" } \\
\text { From correspondence: "The run-in was } \\
\text { single blind (blind to the subject) }\end{array}$ \\
\hline $\begin{array}{l}\text { Blinding? } \\
\text { subjective outcomes; exacerbations requir- } \\
\text { ing OCS, asthma-related SAEs, withdrawal }\end{array}$ & Yes & "double-blind" \\
\hline
\end{tabular}

Reasons for withdrawal not given, although the numbers of withdrawals were in line with those in other trials in this review and 
Villa 2002 (Continued)

balanced between treatment arms

\begin{tabular}{l|l|l} 
Free of selective reporting? & Unclear & $\begin{array}{l}\text { Missing data in study report from AZ. PEF, } \\
\text { number of inhalations, night-time awaken- } \\
\text { ings, days restricted activity, FEV1, quality } \\
\text { of life, adverse events, ECG, blood pressure }\end{array}$ \\
\hline Free of other bias? & No & $\begin{array}{l}\text { Publication bias. Just study report and } 2 \\
\text { conference abstracts. No full paper }\end{array}$ \\
\hline
\end{tabular}

ATS: American Thoracic Society; ECG: electrocardiogram; ER/ED: emergency room/emergency department; FEV1: forced expiratory volume in one second; GINA: Global Initiative for Asthma; GOLD: Global Initiative for Chronic Obstructive Lung Disease; ICS: inhaled corticosteroid; LABA: long-acting beta2-agonist; OCS: oral corticosteroid; PEF: peak expiratory flow; SABA: short-acting beta2-agonist; SAE: serious adverse event

\section{Characteristics of excluded studies [ordered by study ID]}

\begin{tabular}{ll}
\hline Study & Reason for exclusion \\
\hline Bisgaard 2005 & $\begin{array}{l}\text { STAY trial; budesonide/formoterol in a single inhaler as maintenance and reliever compared to same dose single } \\
\text { inhaler as maintenance and terbutaline as reliever }\end{array}$ \\
\hline Boskovska 2001 & Formoterol twice daily versus salbutamol as-needed \\
\hline Cheung 2006 & Cross-over \\
\hline Kesten 1991 & Randomised to formoterol or albuterol twice daily plus albuterol as-needed \\
\hline O'Connor 2000 & Cross-over \\
\hline Richter 2007 & Formoterol as maintenance versus formoterol as-needed \\
\hline
\end{tabular}


DATA AND ANALYSES

Comparison 1. Formoterol versus short-acting beta2-agonist

\begin{tabular}{|c|c|c|c|c|}
\hline Outcome or subgroup title & $\begin{array}{l}\text { No. of } \\
\text { studies }\end{array}$ & $\begin{array}{c}\text { No. of } \\
\text { participants }\end{array}$ & Statistical method & Effect size \\
\hline $\begin{array}{l}1 \text { Patients with an exacerbation } \\
\text { requiring hospitalisation }\end{array}$ & 7 & 22236 & Odds Ratio (M-H, Fixed, 95\% CI) & $0.84[0.67,1.04]$ \\
\hline $\begin{array}{l}2 \text { Patients with an exacerbation } \\
\text { requiring a course of oral } \\
\text { corticosteroids }\end{array}$ & 6 & 21591 & Odds Ratio (M-H, Fixed, 95\% CI) & $0.84[0.77,0.91]$ \\
\hline $\begin{array}{l}3 \text { Fatal serious adverse events } \\
\text { (all-cause) }\end{array}$ & 5 & 21629 & Odds Ratio (M-H, Fixed, 95\% CI) & $1.08[0.51,2.30]$ \\
\hline $\begin{array}{l}4 \text { Patients with a serious adverse } \\
\text { event (all-cause) }\end{array}$ & 7 & 22538 & Odds Ratio (M-H, Fixed, 95\% CI) & $0.94[0.81,1.08]$ \\
\hline $\begin{array}{l}5 \text { Patients with a serious adverse } \\
\text { event (asthma-related) }\end{array}$ & 6 & 21986 & Odds Ratio (M-H, Fixed, 95\% CI) & $0.91[0.72,1.15]$ \\
\hline 6 Peak expiratory flow (morning) & 4 & & Mean Difference (Fixed, 95\% CI) & $3.88[1.29,6.46]$ \\
\hline 7 Peak expiratory flow (evening) & 4 & & Mean Difference (Fixed, 95\% CI) & $2.05[-0.50,4.60]$ \\
\hline $\begin{array}{l}8 \text { Fixed expiratory flow in one } \\
\text { second (FEV1) litres }\end{array}$ & 1 & & Mean Difference (Fixed, 95\% CI) & Totals not selected \\
\hline 9 Change in FEV1 \% predicted & 3 & & Mean Difference (Fixed, 95\% CI) & $0.61[-0.49,1.71]$ \\
\hline 10 Withdrawals (any reason) & 7 & 22541 & Odds Ratio (M-H, Fixed, 95\% CI) & $1.12[1.02,1.24]$ \\
\hline
\end{tabular}

Comparison 2. Formoterol versus short-acting beta2-agonist (background ICS use)

\begin{tabular}{|c|c|c|c|c|}
\hline Outcome or subgroup title & $\begin{array}{l}\text { No. of } \\
\text { studies }\end{array}$ & $\begin{array}{c}\text { No. of } \\
\text { participants }\end{array}$ & Statistical method & Effect size \\
\hline $\begin{array}{l}1 \text { Patients with an exacerbation } \\
\text { requiring a course of oral } \\
\text { corticosteroids }\end{array}$ & 4 & 3669 & Peto Odds Ratio (Peto, Fixed, 95\% CI) & $0.78[0.65,0.94]$ \\
\hline 1.1 Maintenance ICS & 3 & 2994 & Peto Odds Ratio (Peto, Fixed, 95\% CI) & $0.75[0.62,0.91]$ \\
\hline 1.2 No maintenance ICS & 1 & 675 & Peto Odds Ratio (Peto, Fixed, 95\% CI) & $1.47[0.70,3.10]$ \\
\hline $\begin{array}{l}2 \text { Patients with a serious adverse } \\
\quad \text { event (all-cause) }\end{array}$ & 7 & 22538 & Peto Odds Ratio (Peto, Fixed, 95\% CI) & $0.94[0.81,1.08]$ \\
\hline 2.1 Maintenance ICS & 6 & 17785 & Peto Odds Ratio (Peto, Fixed, 95\% CI) & $0.91[0.78,1.06]$ \\
\hline 2.2 No maintenance ICS & 2 & 4753 & Peto Odds Ratio (Peto, Fixed, 95\% CI) & $1.14[0.77,1.69]$ \\
\hline
\end{tabular}


Comparison 3. Formoterol versus short-acting beta2-agonists (background LABA use)

\begin{tabular}{|c|c|c|c|c|}
\hline Outcome or subgroup title & $\begin{array}{l}\text { No. of } \\
\text { studies }\end{array}$ & $\begin{array}{l}\text { No. of } \\
\text { participants }\end{array}$ & Statistical method & Effect size \\
\hline $\begin{array}{l}1 \text { Patients with a serious adverse } \\
\text { event (all-cause) }\end{array}$ & 6 & 21863 & Peto Odds Ratio (Peto, Fixed, 95\% CI) & $0.94[0.81,1.09]$ \\
\hline 1.1 Maintenance LABA & 3 & 8319 & Peto Odds Ratio (Peto, Fixed, 95\% CI) & $0.84[0.68,1.03]$ \\
\hline 1.2 No maintenance LABA & 4 & 13544 & Peto Odds Ratio (Peto, Fixed, 95\% CI) & $1.06[0.86,1.30]$ \\
\hline
\end{tabular}

\section{Analysis I.I. Comparison I Formoterol versus short-acting beta2-agonist, Outcome I Patients with an exacerbation requiring hospitalisation.}

Review: Formoterol versus short-acting beta-agonists as relief medication for adults and children with asthma

Comparison: I Formoterol versus short-acting beta2-agonist

Outcome: I Patients with an exacerbation requiring hospitalisation

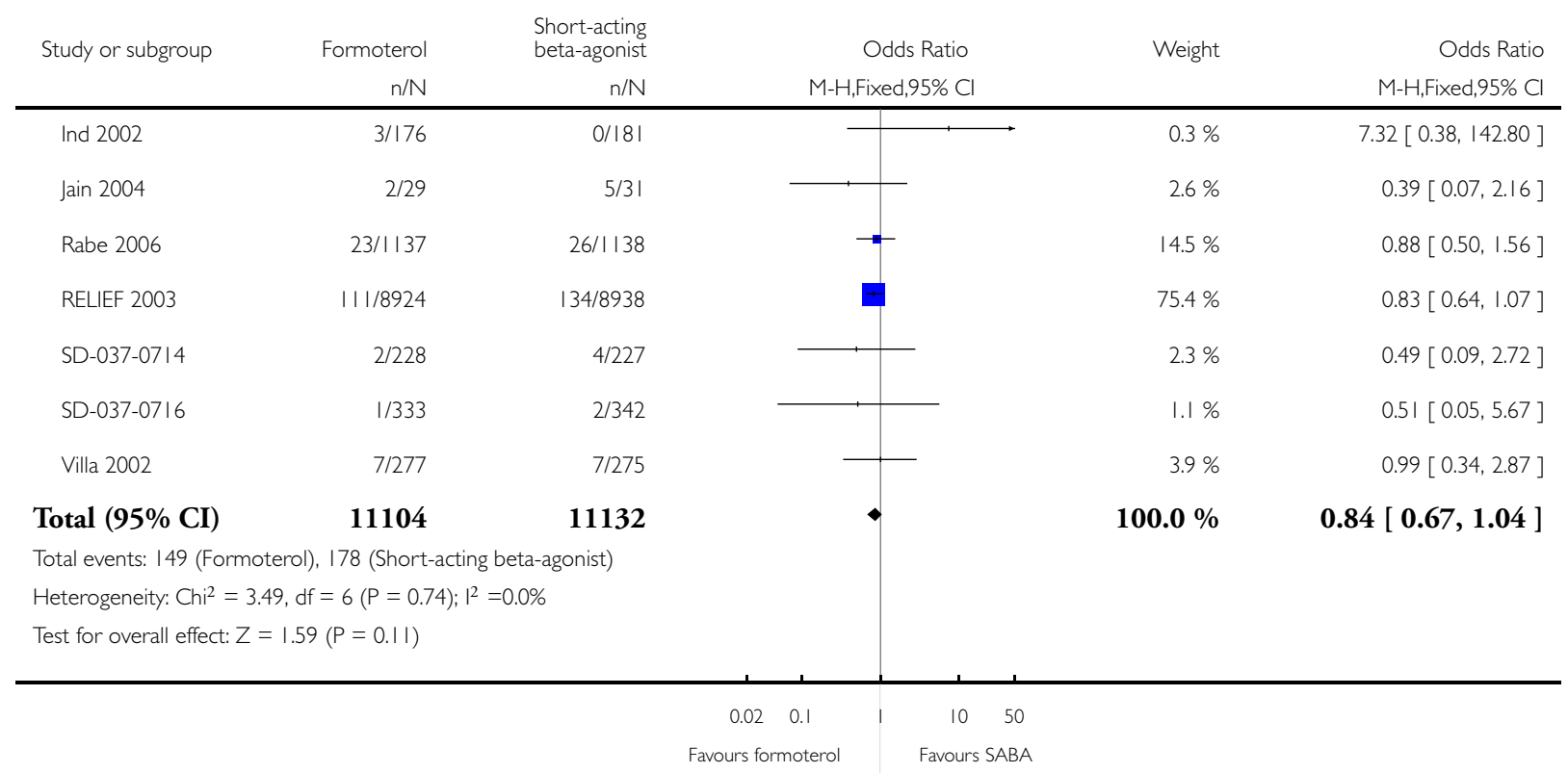


Analysis I.2. Comparison I Formoterol versus short-acting beta2-agonist, Outcome 2 Patients with an exacerbation requiring a course of oral corticosteroids.

Review: Formoterol versus short-acting beta-agonists as relief medication for adults and children with asthma

Comparison: I Formoterol versus short-acting beta2-agonist

Outcome: 2 Patients with an exacerbation requiring a course of oral corticosteroids

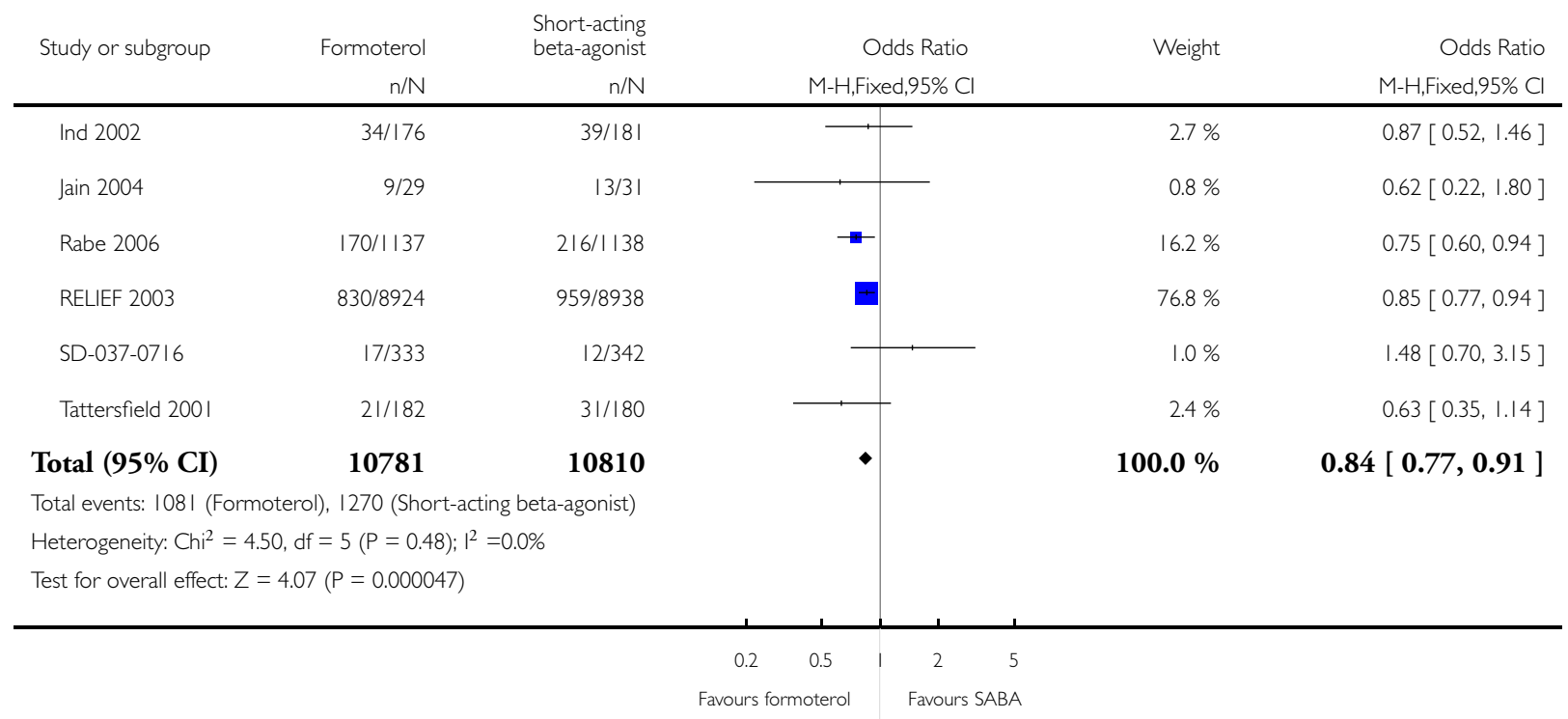


Analysis I.3. Comparison I Formoterol versus short-acting beta2-agonist, Outcome 3 Fatal serious adverse events (all-cause).

Review: Formoterol versus short-acting beta-agonists as relief medication for adults and children with asthma

Comparison: I Formoterol versus short-acting beta2-agonist

Outcome: 3 Fatal serious adverse events (all-cause)

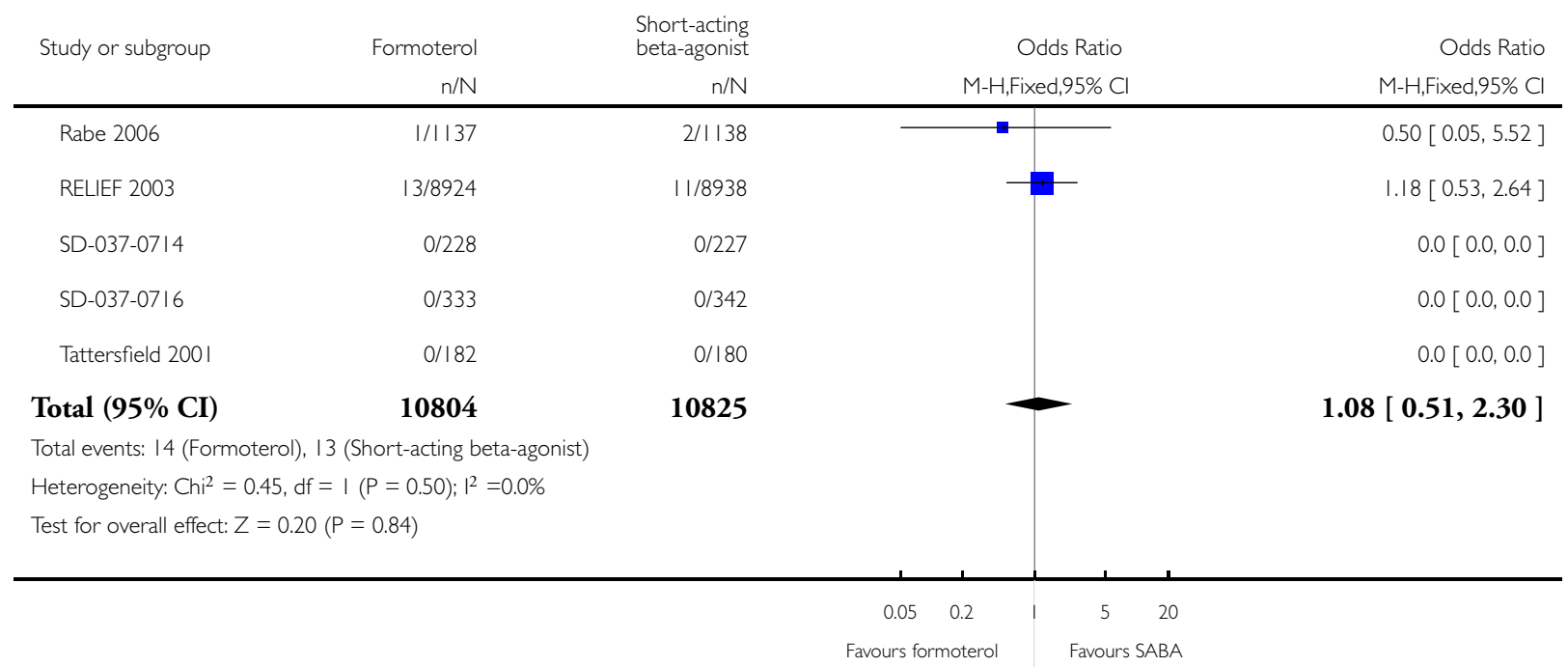


Analysis I.4. Comparison I Formoterol versus short-acting beta2-agonist, Outcome 4 Patients with a serious adverse event (all-cause).

Review: Formoterol versus short-acting beta-agonists as relief medication for adults and children with asthma

Comparison: | Formoterol versus short-acting beta2-agonist

Outcome: 4 Patients with a serious adverse event (all-cause)

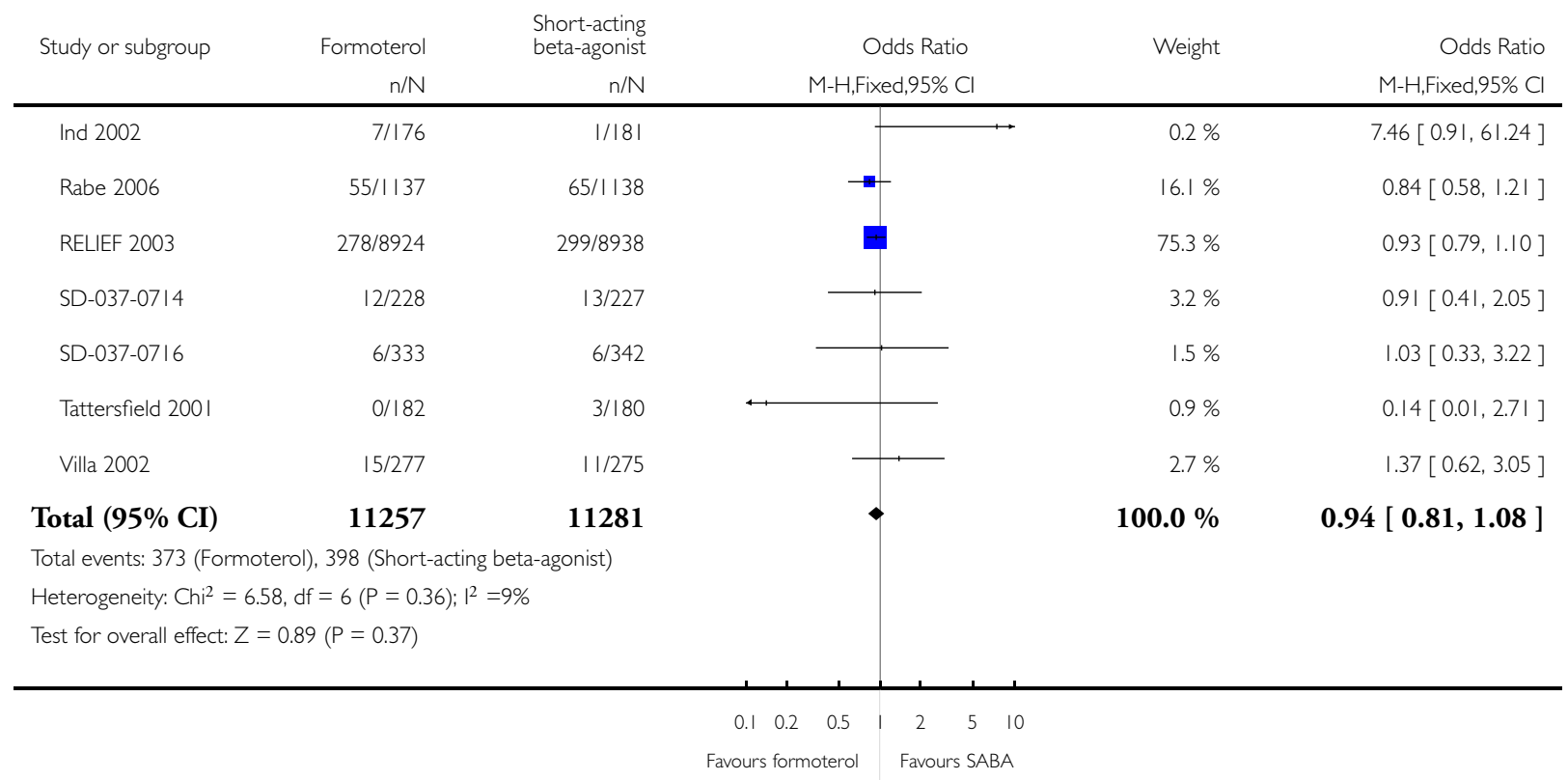


Analysis I.5. Comparison I Formoterol versus short-acting beta2-agonist, Outcome 5 Patients with a serious adverse event (asthma-related).

Review: Formoterol versus short-acting beta-agonists as relief medication for adults and children with asthma

Comparison: I Formoterol versus short-acting beta2-agonist

Outcome: 5 Patients with a serious adverse event (asthma-related)

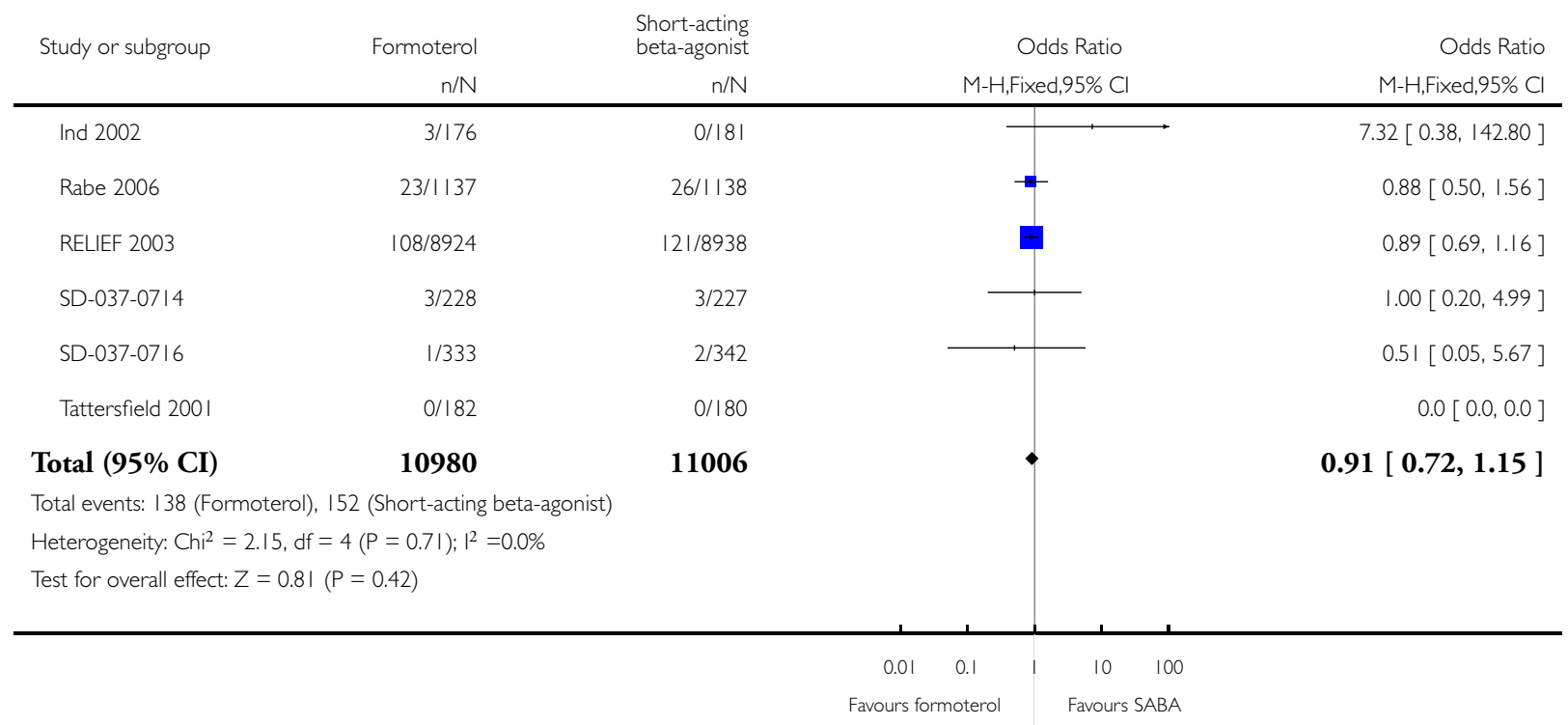


Analysis I.6. Comparison I Formoterol versus short-acting beta2-agonist, Outcome 6 Peak expiratory flow (morning).

Review: Formoterol versus short-acting beta-agonists as relief medication for adults and children with asthma

Comparison: | Formoterol versus short-acting beta2-agonist

Outcome: 6 Peak expiratory flow (morning)

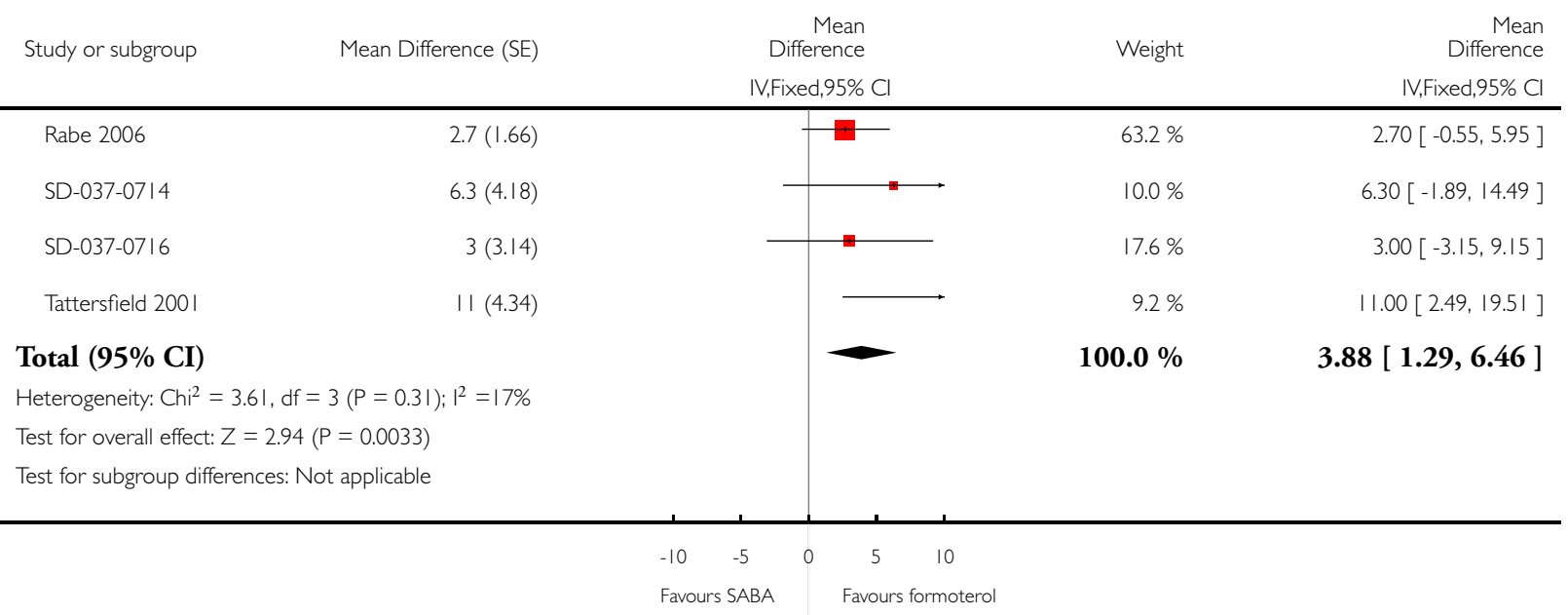


Analysis I.7. Comparison I Formoterol versus short-acting beta2-agonist, Outcome 7 Peak expiratory flow (evening).

Review: Formoterol versus short-acting beta-agonists as relief medication for adults and children with asthma

Comparison: I Formoterol versus short-acting beta2-agonist

Outcome: 7 Peak expiratory flow (evening)

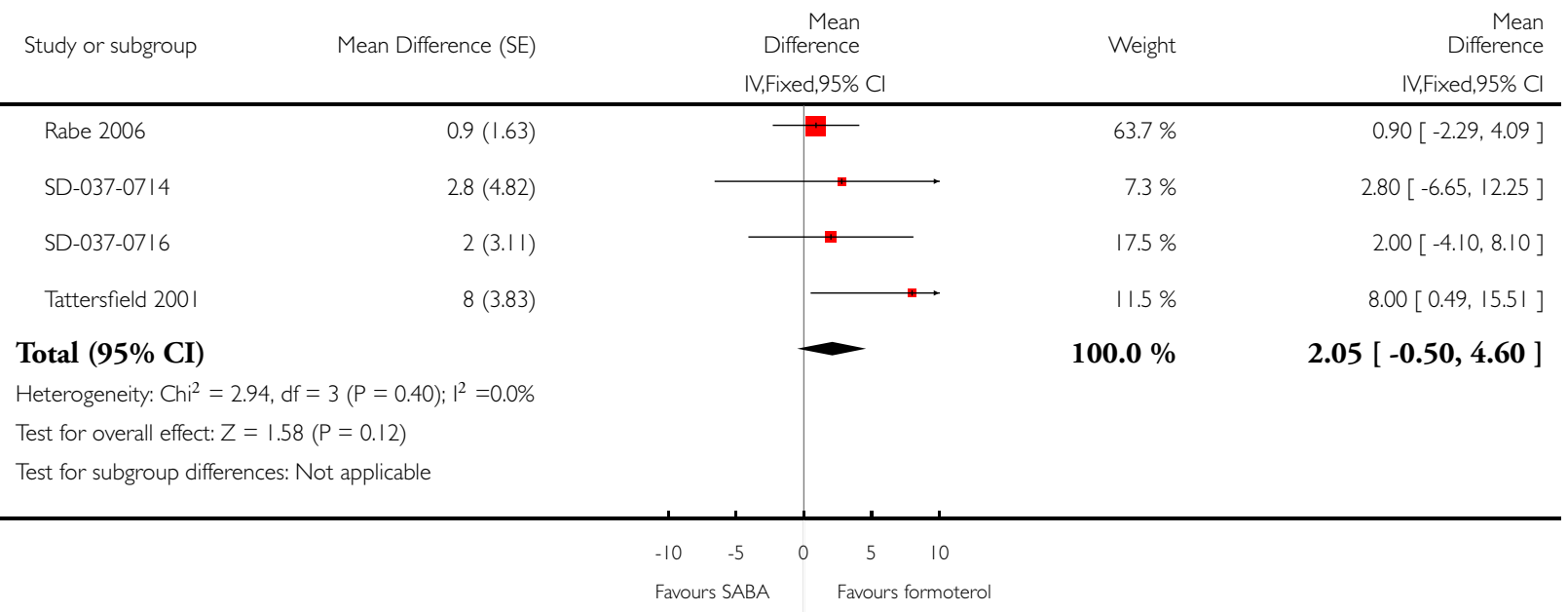

Analysis I.8. Comparison I Formoterol versus short-acting beta2-agonist, Outcome 8 Fixed expiratory flow in one second (FEVI) litres.

Review: Formoterol versus short-acting beta-agonists as relief medication for adults and children with asthma

Comparison: I Formoterol versus short-acting beta2-agonist

Outcome: 8 Fixed expiratory flow in one second (FEVI) litres

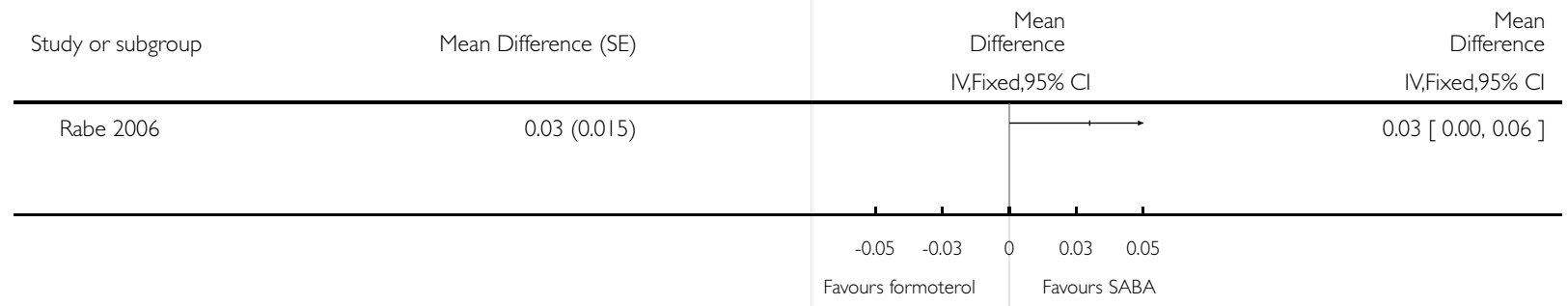


Analysis I.9. Comparison I Formoterol versus short-acting beta2-agonist, Outcome 9 Change in FEV I \% predicted.

Review: Formoterol versus short-acting beta-agonists as relief medication for adults and children with asthma

Comparison: | Formoterol versus short-acting beta2-agonist

Outcome: 9 Change in FEVI \% predicted

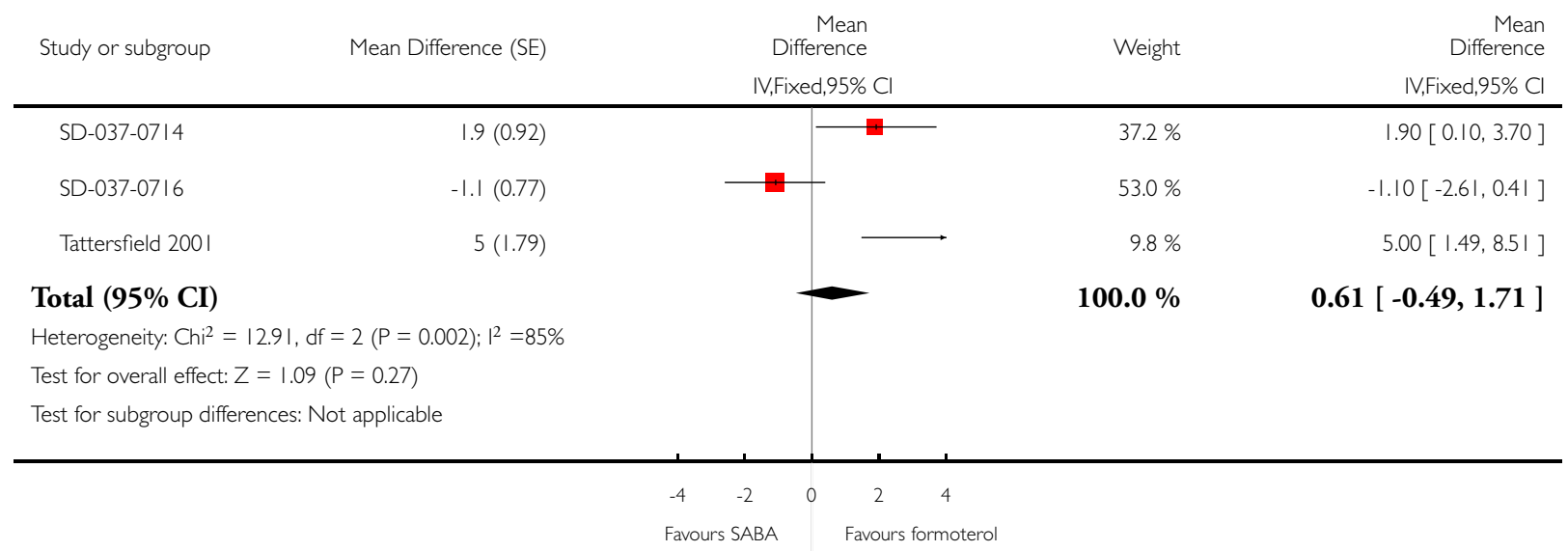


Analysis I.10. Comparison I Formoterol versus short-acting beta2-agonist, Outcome I0 Withdrawals (any reason).

Review: Formoterol versus short-acting beta-agonists as relief medication for adults and children with asthma

Comparison: I Formoterol versus short-acting beta2-agonist

Outcome: 10 Withdrawals (any reason)

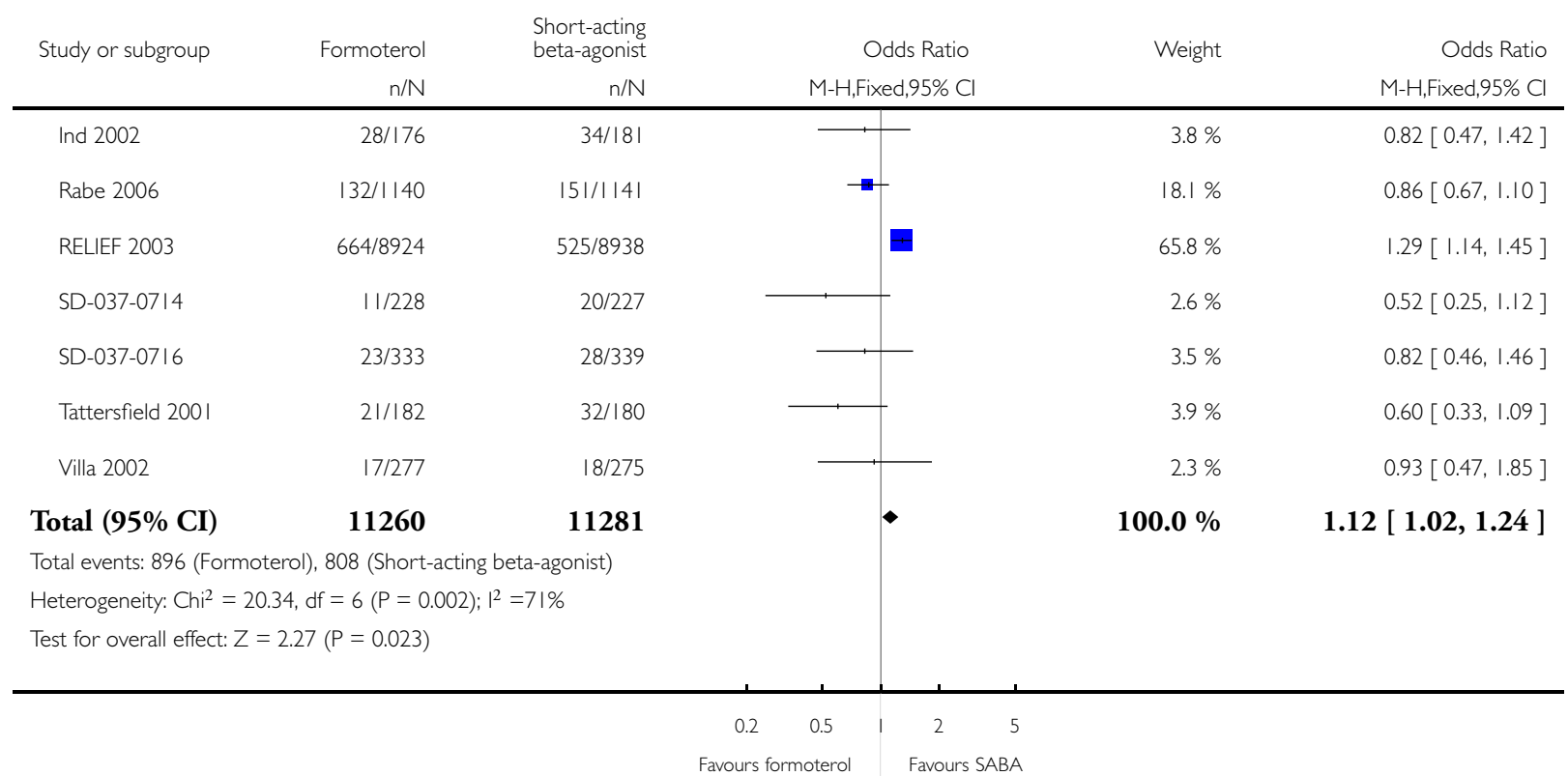


Analysis 2.1. Comparison 2 Formoterol versus short-acting beta2-agonist (background ICS use), Outcome I Patients with an exacerbation requiring a course of oral corticosteroids.

Review: Formoterol versus short-acting beta-agonists as relief medication for adults and children with asthma

Comparison: 2 Formoterol versus short-acting beta2-agonist (background ICS use)

Outcome: I Patients with an exacerbation requiring a course of oral corticosteroids

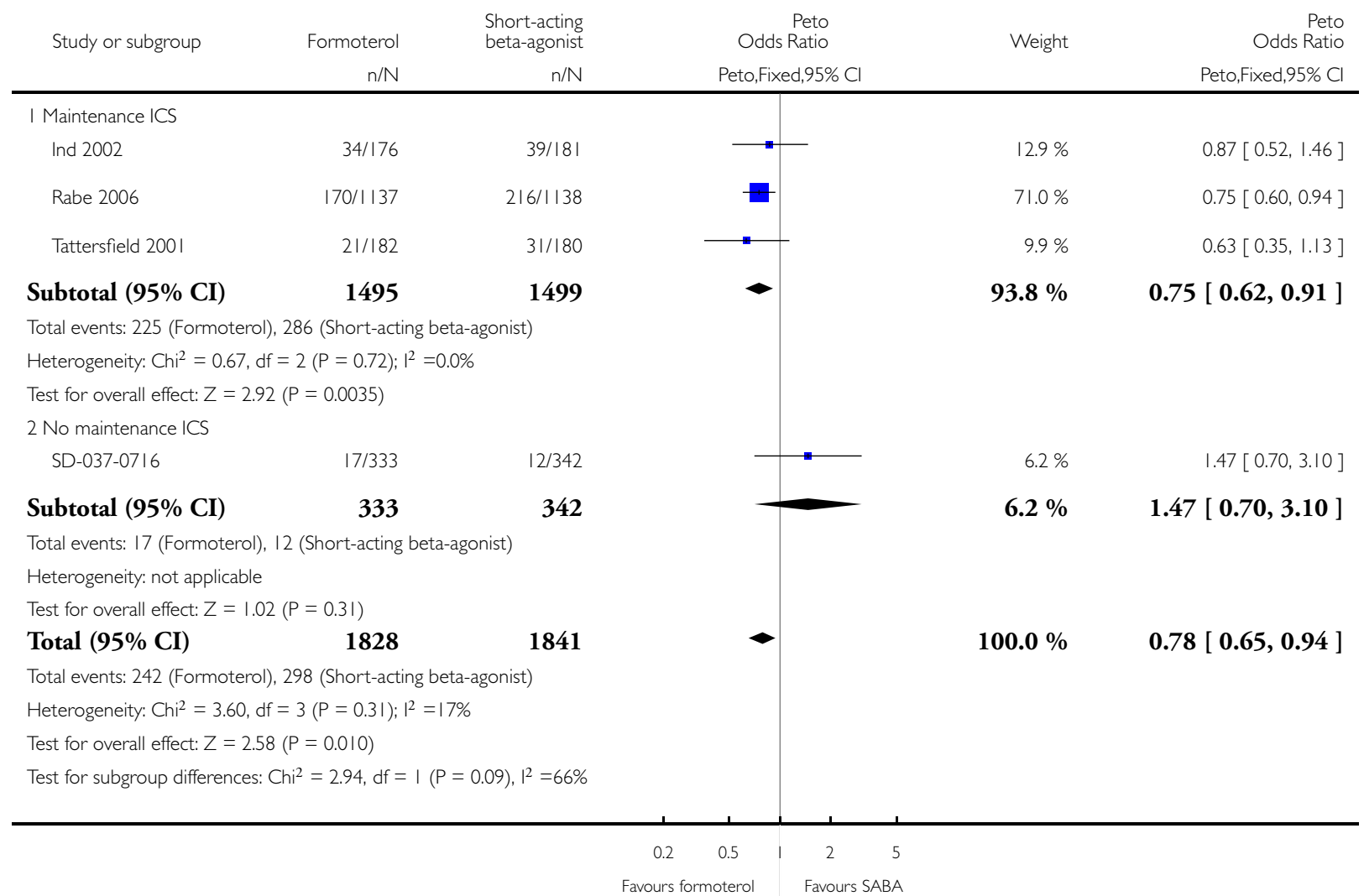


Analysis 2.2. Comparison 2 Formoterol versus short-acting beta2-agonist (background ICS use), Outcome 2 Patients with a serious adverse event (all-cause).

Review: Formoterol versus short-acting beta-agonists as relief medication for adults and children with asthma

Comparison: 2 Formoterol versus short-acting beta2-agonist (background ICS use)

Outcome: 2 Patients with a serious adverse event (all-cause)

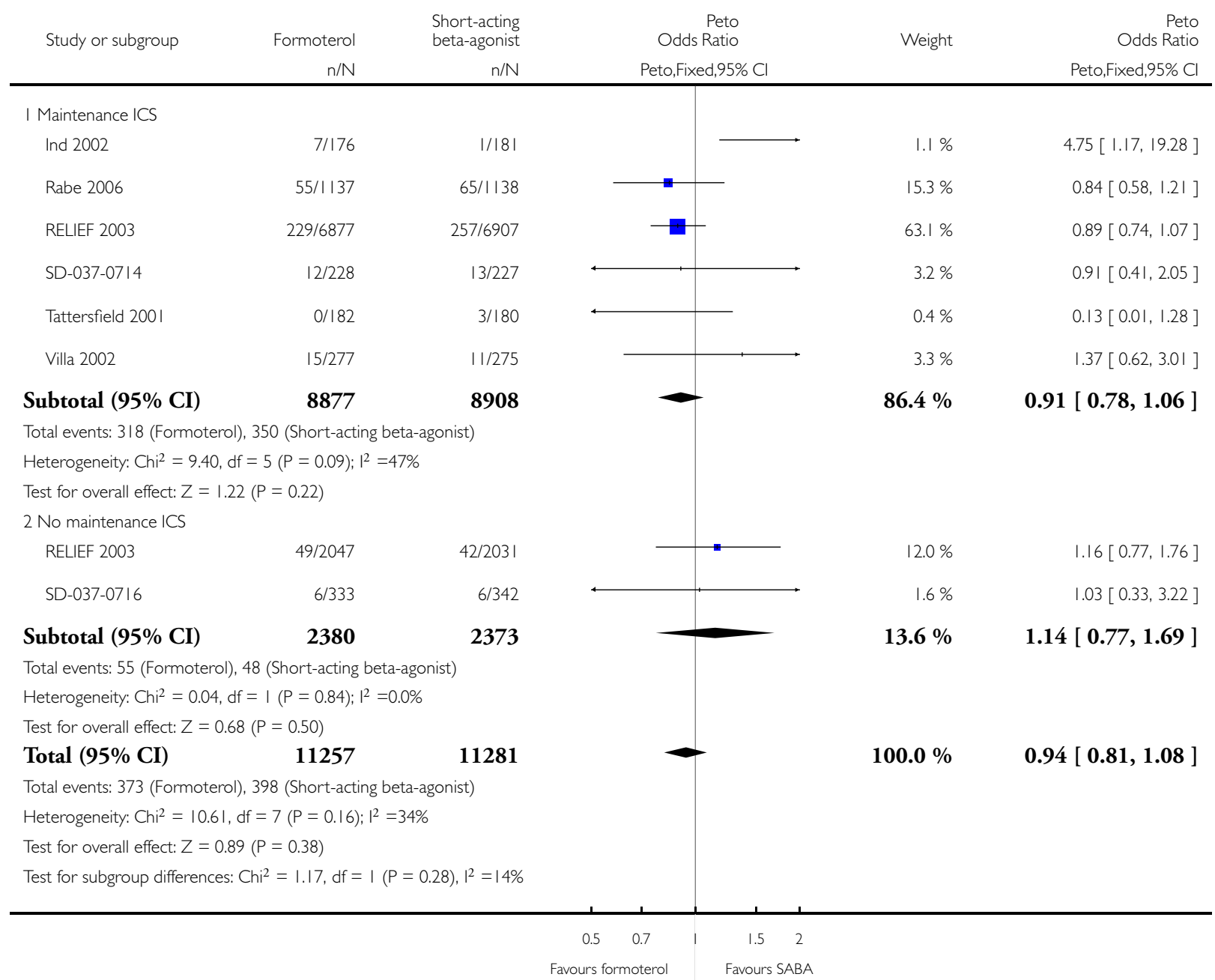


Analysis 3.I. Comparison 3 Formoterol versus short-acting beta2-agonists (background LABA use), Outcome I Patients with a serious adverse event (all-cause).

Review: Formoterol versus short-acting beta-agonists as relief medication for adults and children with asthma

Comparison: 3 Formoterol versus short-acting beta2-agonists (background LABA use)

Outcome: I Patients with a serious adverse event (all-cause)

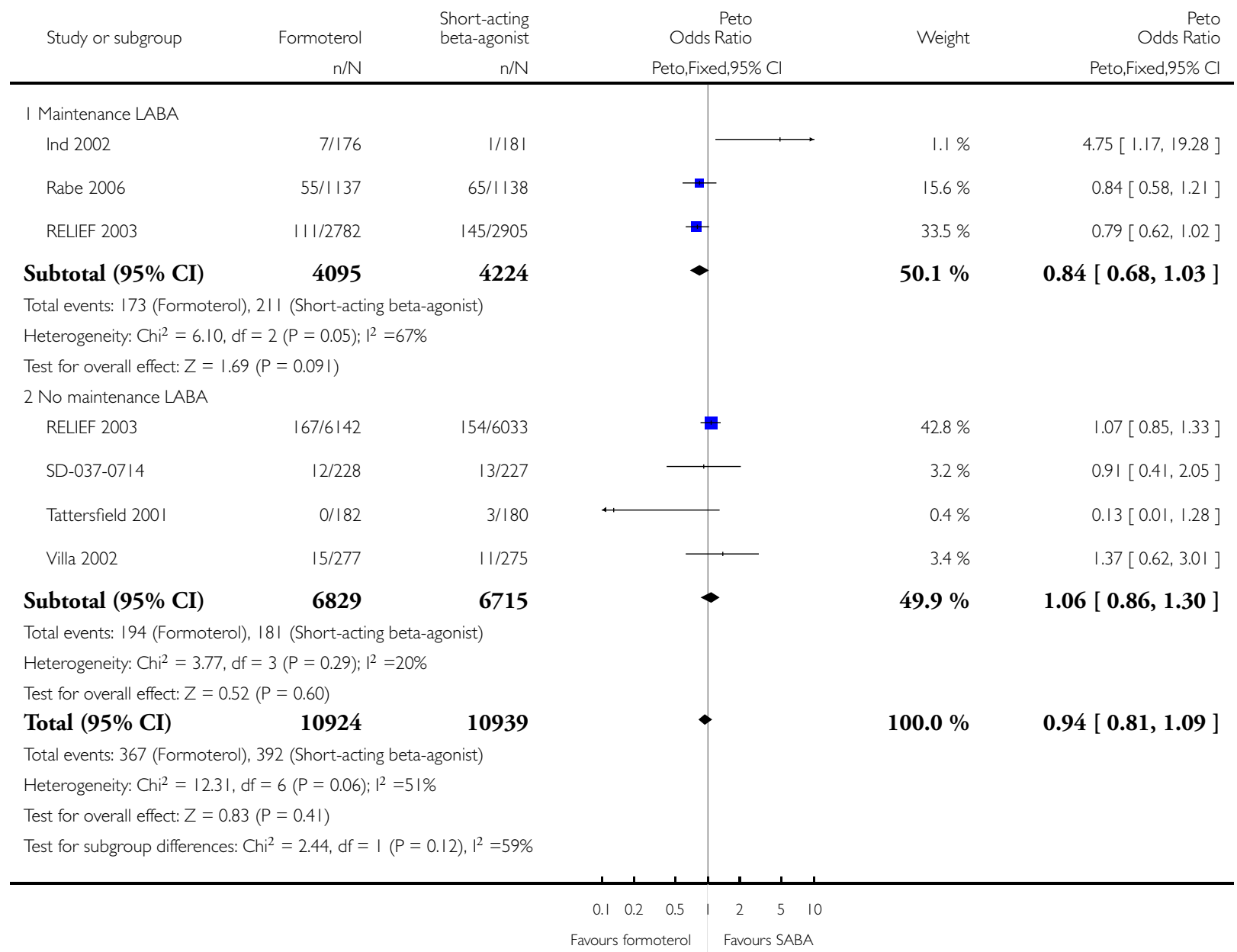

ADDITIONAL TABLES 
Table 1. Randomised as-needed medication and maintenance therapies

\begin{tabular}{|c|c|c|c|}
\hline Study ID & $\begin{array}{l}\text { Intervention as-needed medica- } \\
\text { tion [mean daily puffs (range)] }\end{array}$ & $\begin{array}{l}\text { Control medication as-needed } \\
\text { [mean daily puffs (range)] }\end{array}$ & $\begin{array}{l}\text { Maintenance medication [mean } \\
\text { daily ICS dose] }\end{array}$ \\
\hline Ind 2002 & $\begin{array}{l}\text { Formoterol, } 4.5 \mu \mathrm{g} \text { DPI } \\
{[2.16(0.00 \text { to } 6.3)]}\end{array}$ & $\begin{array}{l}\text { Terbutaline, } 0.5 \mathrm{mg} \text { DPI } \\
{[2.34(0.1 \text { to } 7.5)]}\end{array}$ & $\begin{array}{l}\text { All on formoterol, } 9 \mu \mathrm{g} \text { DPI, twice } \\
\text { a day and maintenance inhaled or } \\
\text { oral corticosteroids }\end{array}$ \\
\hline Jain 2004 & Formoterol, $4.5 \mu \mathrm{g}$ DPI & Salbutamol, $100 \mu \mathrm{g}$ DPI & Not stated \\
\hline Rabe 2006 & $\begin{array}{l}\text { Formoterol, } 4.5 \mu \mathrm{g} \text { DPI } \\
{[1.9(0.0 \text { to } 9.1)]}\end{array}$ & $\begin{array}{l}\text { Terbutaline, } 0.4 \mathrm{mg} \text { DPI } \\
{[1.9(0.3 \text { to } 9.7)]}\end{array}$ & $\begin{array}{l}\text { Budesonide/formoterol, 160/4.5 } \mu \mathrm{g} \\
\text { DPI combined inhaler }\end{array}$ \\
\hline RELIEF 2003 & Formoterol, $4.5 \mu \mathrm{g}$ DPI & $\begin{array}{l}\text { Salbutamol, } 200 \mu \mathrm{g} \text { DPI ( } 6 \text { coun- } \\
\text { tries) or PMDI ( } 18 \text { countries })\end{array}$ & $\begin{array}{l}\text { Any ordinary asthma medication } \\
\text { apart from other relief medication, } \\
\text { changes in maintenance medication } \\
\text { allowed }[76 \% \text { participants on } 760 \\
\mu \mathrm{g}]\end{array}$ \\
\hline SD-037-0714 & Formoterol, $4.5 \mu \mathrm{g}$ DPI & Terbutaline, $0.5 \mathrm{mg}$ DPI & $\begin{array}{l}\text { All on inhaled corticosteroids ([380 } \\
\mu \mathrm{g}] 200 \text { to } 500 \mu \mathrm{g} \text { per day), but not } \\
\text { long-acting beta } 2 \text {-agonists }\end{array}$ \\
\hline SD-037-0716 & Formoterol, $4.5 \mu \mathrm{g}$ DPI & Terbutaline, $0.5 \mathrm{mg}$ DPI & $\begin{array}{l}\text { Not inhaled corticosteroids or other } \\
\text { anti-inflammatories }\end{array}$ \\
\hline Tattersfield 2001 & $\begin{array}{l}\text { Formoterol, } 4.5 \mu \mathrm{g} \text { DPI } \\
{[3.92]}\end{array}$ & $\begin{array}{l}\text { Terbutaline, } 0.5 \mathrm{mg} \text { DPI } \\
{[4.89]}\end{array}$ & $\begin{array}{l}\text { All on inhaled corticosteroids [ } 875 \\
\mu \mathrm{g} \text {. No beta } 2 \text {-agonists allowed but } \\
\text { other asthma medications at con- } \\
\text { stant dosage permitted }\end{array}$ \\
\hline Villa 2002 & Formoterol, $4.5 \mu \mathrm{g}$ DPI & Terbutaline, $0.25 \mathrm{mg}$ DPI & $\begin{array}{l}\text { Inhaled } \\
\text { corticosteroids }[410 \mu \mathrm{g} \text { ], disodium } \\
\text { cromoglycate or nedocromil }\end{array}$ \\
\hline
\end{tabular}

DPI ; Dry power inhaler; PMDI: pressurised metered dose inhaler.

Table 2. Study characteristics

\begin{tabular}{|c|c|c|c|c|c|c|}
\hline Study ID & $\begin{array}{l}\text { Number of par- } \\
\text { ticipants }\end{array}$ & Duration & Mean age (range) & $\begin{array}{l}\text { Locale centres } \\
\text { (countries) }\end{array}$ & Asthma severity & Sponsor \\
\hline Ind 2002 & 375 & 12 weeks & 47 & $42(5)$ & stable on ICS & $\mathrm{AZ}$ \\
\hline Jain 2004 & 60 & 6 months & $?$ & $?$ & $?$ & $?$ \\
\hline Rabe 2006 & 2281 & 12 months & $42(12$ to 81$)$ & $289(20)$ & moderate to severe & AZ \\
\hline
\end{tabular}


Table 2. Study characteristics (Continued)

\begin{tabular}{|c|c|c|c|c|c|c|}
\hline RELIEF 2003 & 17,862 & 6 months & 39 (4 to 91$)$ & $1139(24)$ & $\begin{array}{l}\text { intermittent, } \\
\text { mild, moderate or } \\
\text { severe }\end{array}$ & $\mathrm{AZ}$ \\
\hline SD-037-0714 & 455 & 12 months & $25(6$ to 75$)$ & $48(4)$ & mild & $\mathrm{AZ}$ \\
\hline SD-037-0716 & 675 & 12 months & 24 (6 to 87$)$ & $54(8)$ & intermittent & $\mathrm{AZ}$ \\
\hline Tattersfield 2001 & 362 & 12 weeks & 47 (18 to 75$)$ & $35(4)$ & mild to moderate & AZ \\
\hline Villa 2002 & 552 & 6 months & $11(5$ to 19$)$ & 77 (9) & $\begin{array}{l}\text { mild or moderate } \\
\text { persistent }\end{array}$ & AZ \\
\hline
\end{tabular}

Table 3. Withdrawals

\begin{tabular}{|c|c|c|c|c|c|c|c|c|c|c|}
\hline \multirow[t]{2}{*}{ Study ID } & \multicolumn{2}{|c|}{ Eligibility criteria } & \multicolumn{2}{|c|}{$\begin{array}{l}\text { Discontinuations due } \\
\text { to adverse events }\end{array}$} & \multicolumn{2}{|c|}{ Lost to follow up } & \multicolumn{2}{|c|}{$\begin{array}{l}\text { Total numbers of } \\
\text { withdrawals }\end{array}$} & \multicolumn{2}{|l|}{$\mathbf{N}$} \\
\hline & $\begin{array}{l}\text { For- } \\
\text { moterol }\end{array}$ & SABA & $\begin{array}{l}\text { For- } \\
\text { moterol }\end{array}$ & SABA & $\begin{array}{l}\text { For- } \\
\text { moterol }\end{array}$ & SABA & $\begin{array}{l}\text { For- } \\
\text { moterol }\end{array}$ & SABA & $\begin{array}{l}\text { For- } \\
\text { moterol }\end{array}$ & SABA \\
\hline Ind 2002 & 8 & 9 & 14 & 14 & 1 & 8 & $\begin{array}{ll}28 & (15 . \\
9 \%) & \end{array}$ & $\begin{array}{ll}34 & (18 . \\
8 \%) & \end{array}$ & 176 & 181 \\
\hline $\begin{array}{l}\text { Rabe } \\
2006\end{array}$ & 50 & 56 & $22(1.9 \%)$ & $19(1.6 \%)$ & $14(1.2 \%)$ & $9(1.6 \%)$ & $\begin{array}{l}132 \\
5 \%)\end{array}$ & $\begin{array}{l}151 \\
(13 \%)\end{array}$ & 1140 & 1141 \\
\hline $\begin{array}{l}\text { RELIEF } \\
2003\end{array}$ & 12 & 21 & $\begin{array}{l}213 \\
4 \%)\end{array}$ & $\begin{array}{l}119 \\
3 \%)\end{array}$ & $\begin{array}{l}221 \\
5 \%)\end{array}$ & $\begin{array}{l}204 \\
2 \%)\end{array}$ & $\begin{array}{l}664 \\
4 \%)\end{array}$ & $\begin{array}{l}525 \\
9 \%)\end{array}$ & 8924 & 8938 \\
\hline $\begin{array}{l}\text { SD-037- } \\
0714\end{array}$ & 2 & 3 & 2 & 3 & - & - & $11(4.8 \%)$ & $20(8.8 \%)$ & 228 & 227 \\
\hline $\begin{array}{l}\text { SD-037- } \\
0716\end{array}$ & - & - & 0 & 2 & - & - & $23(6.9 \%)$ & $28(8.3 \%)$ & 333 & 339 \\
\hline $\begin{array}{l}\text { Tatters- } \\
\text { field } \\
2001\end{array}$ & - & - & 8 & 18 & - & - & $21(6.3 \%)$ & $\begin{array}{ll}32 & (17 . \\
8 \%) & \end{array}$ & 182 & 180 \\
\hline $\begin{array}{l}\text { Villa } \\
2002\end{array}$ & - & - & $3 \%$ & $3 \%$ & - & - & $17(7.5 \%)$ & $18(6.5 \%)$ & 227 & 275 \\
\hline
\end{tabular}




\section{H I S T O R Y}

Protocol first published: Issue 3, 2010

Review first published: Issue 9, 2010

\section{CONTRIBUTIONS OFAUTHORS}

EJW extracted information for the characteristics of included studies and CJC checked them. CJC and EJW independently extracted the data and entered data into RevMan. EJW drafted the review with input from CJC.

CJC and EJW co-authored the protocol.

\section{DECLARATIONS OF INTEREST}

None known.

\section{SOURCES OF SUPPORT}

\section{Internal sources}

- No sources of support supplied

\section{External sources}

- NIHR, UK.

Funding for research time for CJC and EW

\section{DIFFERENCES BETWEEN PROTOCOL AND REVIEW}

We did not perform subgroup analyses on the basis of age or asthma severity.

We did not ask trialists for separate data for adults and children.

\section{NDEX TERMS}

\section{Medical Subject Headings (MeSH)}

Age Factors; Albuterol [therapeutic use]; Asthma [*drug therapy]; Bronchodilator Agents [* therapeutic use]; Budesonide [therapeutic use]; Cromolyn Sodium [therapeutic use]; Ethanolamines [ ${ }^{*}$ therapeutic use]; Nedocromil [therapeutic use]; Randomized Controlled Trials as Topic; Terbutaline [therapeutic use] 


\section{MeSH check words}

Adult; Child; Humans

Copyright (@) 2010 The Cochrane Collaboration. Published by John Wiley \& Sons, Ltd. 